\title{
Análise de genes moduladores do fenótipo de virilização genital em mulheres com a forma clássica da deficiência da 21-hidroxilase
}

Tese apresentada à Faculdade de Medicina da Universidade de São Paulo para obtenção do título de Doutor em Ciências

Programa: Ciências Médicas

Área de concentração: Distúrbios Genéticos de Desenvolvimento e Metabolismo

Orientadora: Profa. Dra. Tânia Aparecida Sartori Sanchez Bachega

São Paulo 
Dados Internacionais de Catalogação na Publicação (CIP)

Preparada pela Biblioteca da

Faculdade de Medicina da Universidade de São Paulo

Creprodução autorizada pelo autor

\section{Kaupert, Laura Cesar}

Análise de genes moduladores do fenótipo de virilização genital em mulheres com a forma clássica da deficiência da 21-hidroxilase / Laura Cesar Kaupert. -São Paulo, 2012.

Tese(doutorado)--Faculdade de Medicina da Universidade de São Paulo. Programa de Ciências Médicas. Área de concentração: Distúrbios Genéticos de Desenvolvimento e Metabolismo.

Orientadora: Tânia Aparecida Sartori Sanchez Bachega.

Descritores: 1.Hiperplasia supra-renal congênita 2.Virilismo 3.Polimorfismo genético 4.Expressão gênica

USP/FM/DBD-225/12 


\section{DEDICATÓRIA}

Dedico o fim deste projeto e o começo de uma nova etapa à minha mãe, Dulce, a principal responsável pelo início, meio e fim da tese. Obrigada mãe por ter me colocado neste caminho e por estar presente em todos os momentos da minha vida.

Ao meu pai, Vanildo, pelos carinhosos conselhos e pela demonstração de perseverança.

Aos meus irmãos, Denise, Marcos, Gabriel e Fernando por serem meus eternos amigos.

À minha nova família, ao Gabriel, Mirian e Manoel Cintra, pelo novo conceito de vida.

Ao meu noivo Gabriel, por me ensinar a amar, respeitar e trabalhar bastante.

À Mirian, pelo maior exemplo de dedicação e carinho.

Ao Manoel, pelo exemplo de solidariedade e honestidade. 


\section{AGRADECIMENTOS}

À Profa. Dra. Berenice B. de Mendonça por saber conduzir o Laboratório de Endocrinologia da maneira competente, humana e serena.

À Profa. Dra. Tânia A. S. S. Bachega pelo incentivo inicial e em todas as etapas deste longo processo.

À Dra. Ana Elisa C. Billerbeck pela amizade e por tudo o que conheço de biologia molecular.

À Dra. Luciana Brito pelo interesse no estudo e por todas as etapas da expressão gênica.

Ao Dr. Vinícius N. Brito pelas infinitas análises estatísticas.

Ao meu amigo Dr. Antonio M. Lerário, por ser um médico/pesquisador brilhante e por dividir um pouco comigo.

Ao Dr. Alexander Jorge pelas sugestões pertinentes e pelas análises estatísticas.

À Dra. Elaine Costa pelas excelentes conversas, não apenas sobre trabalho, mas sobre a vida.

Ao Prof. Dr. Ivo Arnold pela sua generosidade e intelectualidade.

À Dra. Larissa Gomes pelos bons conselhos.

À Dra. Marlene Inácio e à Dra. Guiomar Madureira pelo atendimento as pacientes no ambulatório médico.

À Dra. Cândida pela sua energia positiva em tudo.

Ao Dr. Marcelo Baptista por ser o primeiro a me acolher no laboratório.

À Valéria Lando pela sua amizade e por ter sido uma ótima chefe.

À amiga Dra. Mirian Nishi por ter uma participação incrível em tudo no Laboratório. 
À amiga Mariana Funari pelo exemplo de competência e boa vontade em tudo o que faz.

Ao Dr. Madson A. Queiroz pela disponibilidade em me ajudar quando precisei.

À Dra. Luciani Carvalho pela paciência de ensinar e compartilhar suas experiências. Ao aluno Ricardo Paranhos pela dedicação e por ser tão ativo.

À Cristina Rossi não apenas pelas amostras de DNA, mas pelo seu bom humor.

Ao Dr. Frederico A. Silva por me auxiliar na coleta das amostras durante as cirurgias de genitoplastia.

À Dra. Maria Helena Valassi pelos muitos auxílios no centro cirúrgico.

As Pacientes deste estudo, que são o objetivo desta pesquisa.

A minha família por permanecer comigo em todos os momentos.

Ao meu noivo Gabriel por sua paciência e amor.

A todos os amigos e colegas de trabalho, que de alguma maneira tornaram meus dias mais divertidos, leves e sorridentes.

Por fim a FAPESP pelo apoio financeiro, por que provavelmente sem ela, nada disso seria possível. 
“Não é o mais forte que sobrevive, nem o mais inteligente, mas o que melhor se adapta às mudanças."

\section{Charles Darwin}

$(1809-1882)$ 


\section{Sumário}

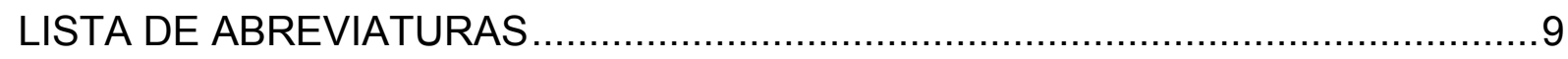

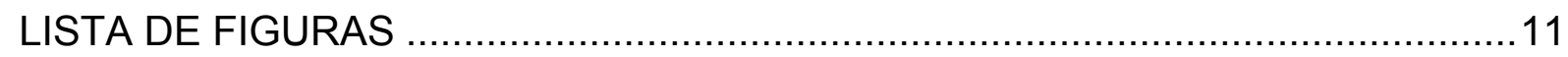

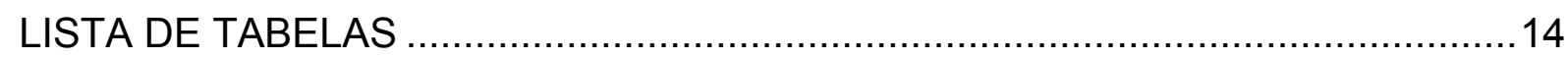

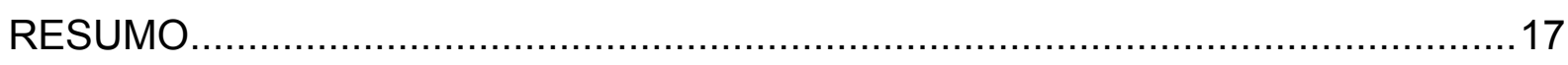

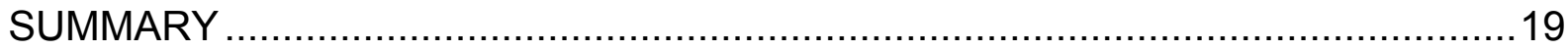

1. INTRODUÇÃO

1.1 Hiperplasia Adrenal Congênita por Deficiência da 21-Hidroxilase ..................22

1.2 Genética Molecular da Hiperplasia Adrenal Congênita por Deficiência da 21-

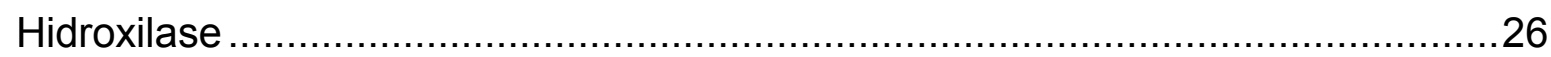

1.3 Genes Relacionados com a Metabolização Androgênica Fetal .....................30

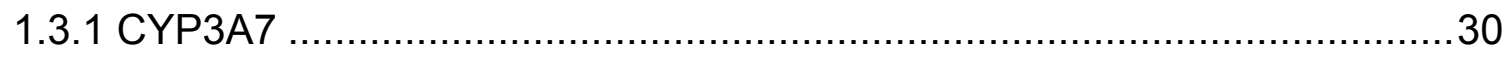

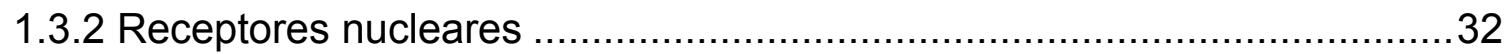

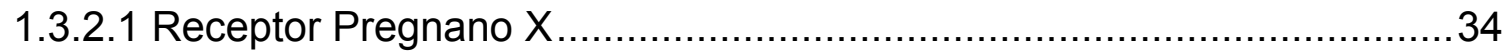

1.3.2.2 Receptor Androstano Constitutivo ................................................... 34

1.4 Genes relacionados a biossíntese androgênica ................................... 35

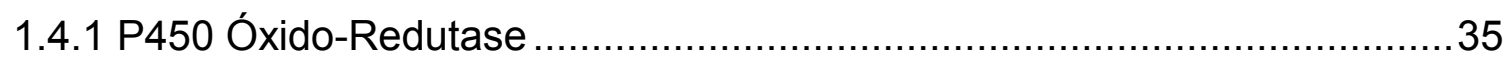

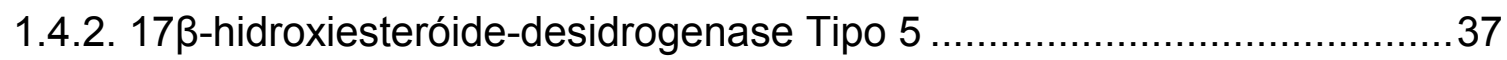

1.5 Genes relacionados a ação periférica androgênica ....................................38

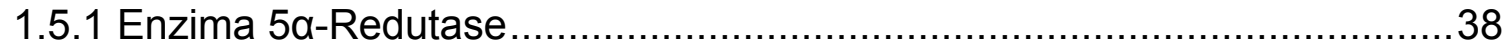

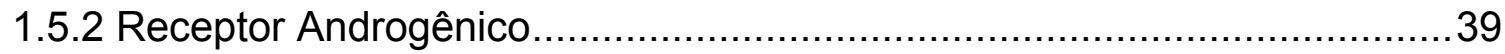

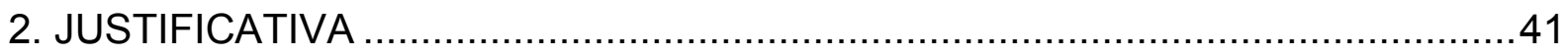

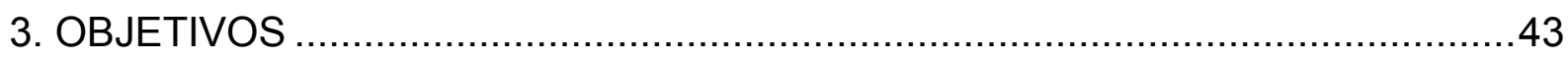

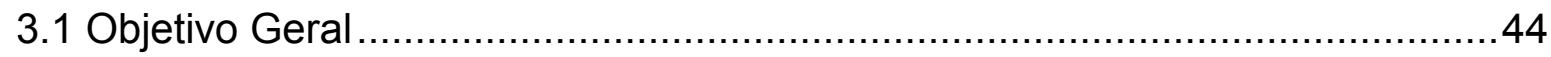

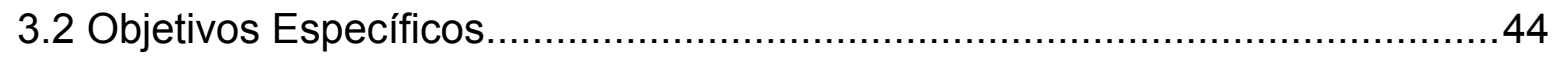

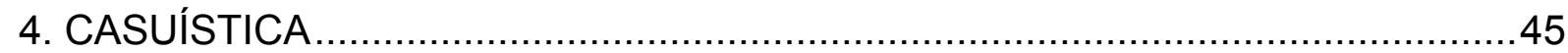


5. MÉTODOS

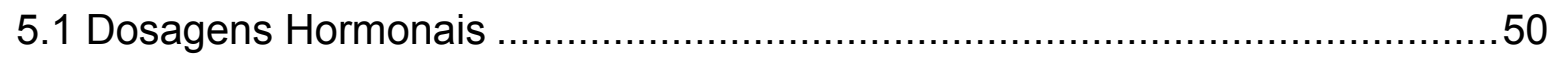

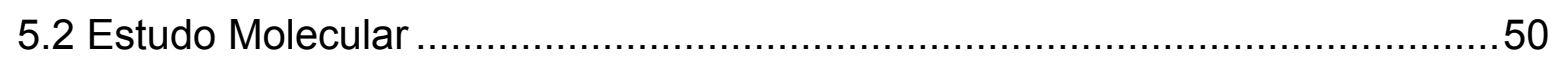

5.3 Amplificação do DNA pela Reação em Cadeia da Polimerase .........................50

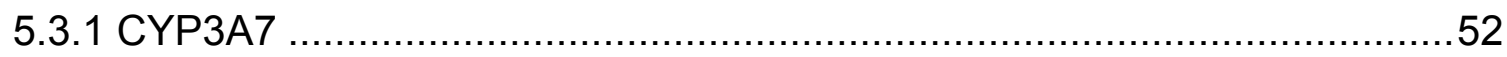

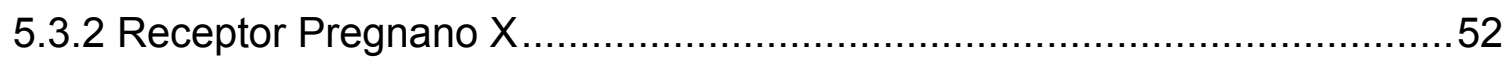

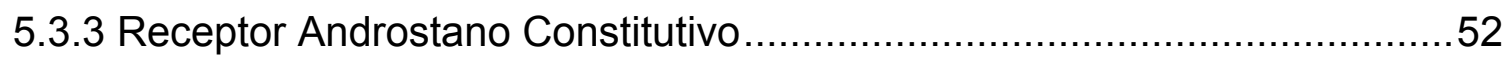

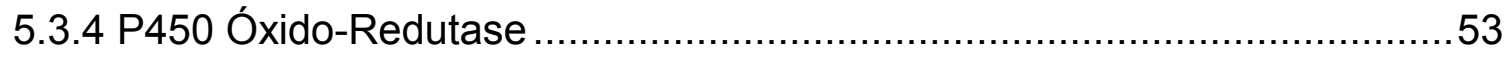

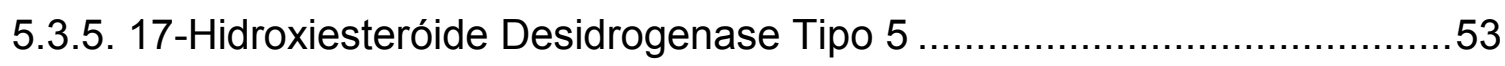

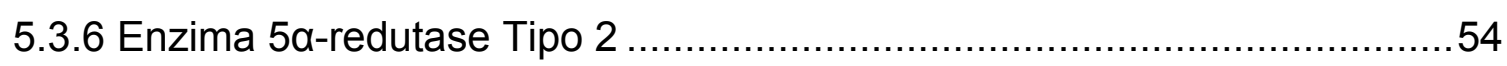

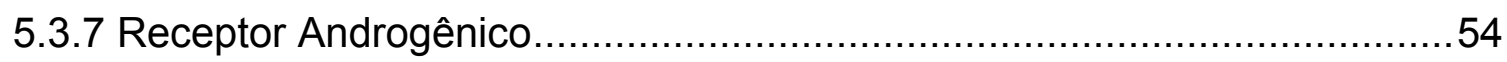

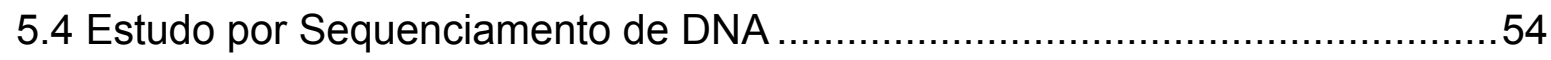

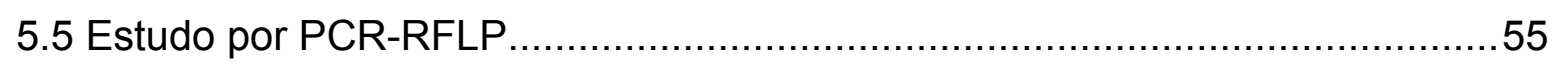

5.6 Análise de Fragmentos pelo Método GeneScan ……..............................57

5.7 Estudo Funcional da Expressão Gênica Diferencial em Pele Genital...............58

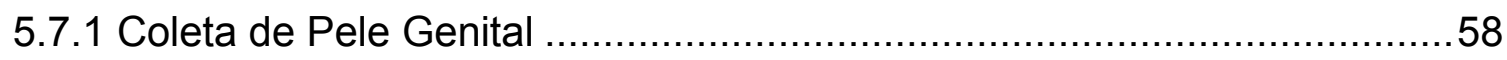

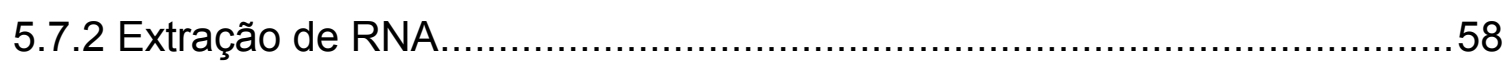

5.7.3 Avaliação da Qualidade/Quantificação do RNA e Síntese do cDNA.........59

5.7.4 Quantificação da Expressão Gênica Diferencial pelo Sistema Taqman....61

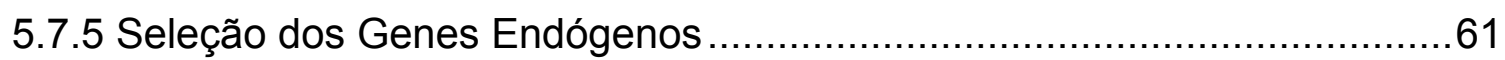

5.7.6 Quantificação Relativa dos Genes Alvos ............................................62

5.7.7 Padronização das Curvas de Eficiência ..................................................63

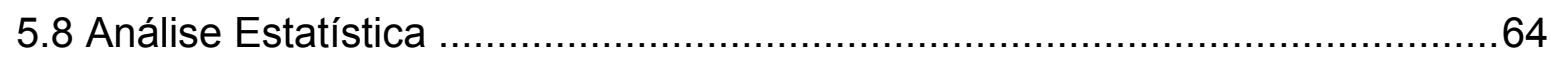

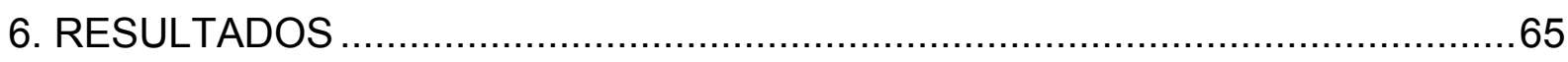

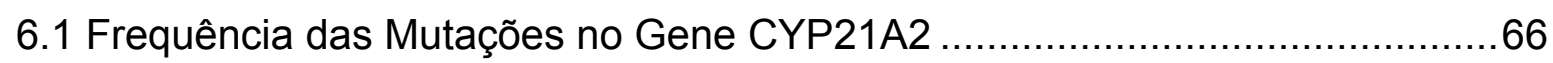

6.2 Correlação entre os Genótipos $210 \mathrm{H}$ e as Formas Clínicas ..........................66

6.3 Correlação entre os Genótipos 210H e as Concentrações Basais Hormonais

6.4 Correlação do Prader score com os Genótipos $210 \mathrm{H}$ e com as Concentrações

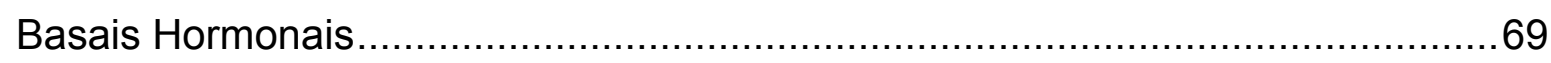

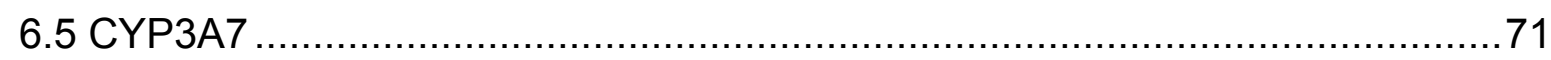




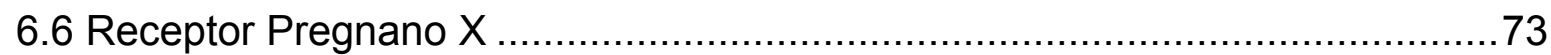

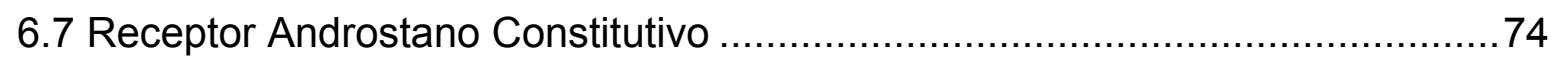

6.8 Correlação das Variantes dos Genes CYP3A7, PXR e CAR com o Grau de

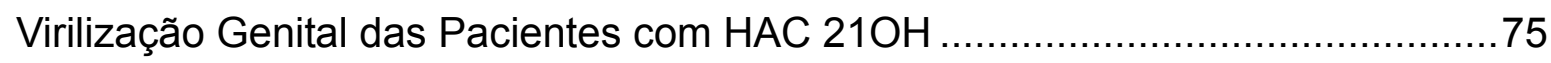

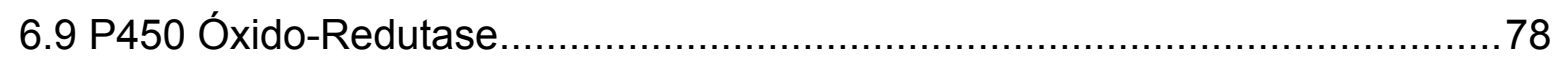

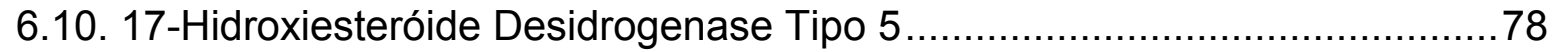

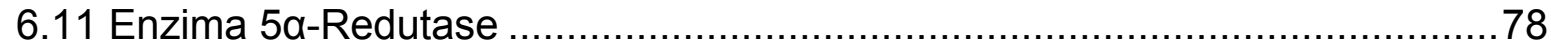

6.12 Correlação das Variantes Funcionais A503V POR, -71G HSD17B5, V89L SRD5A2 e A49T SRD5A2 com o Grau de Virilização Genital.............................79

6.13 Receptor Androgênico ............................................................... 81

6.13.1 Comparação do nCAG com o grau de virilização genital ........................81

6.14 Correlação das Variantes Funcionais A503V POR, -71G HSD17B5, V89L SRD5A2 e nCAG do RA com o Grau de Virilização Genital ................................83

6.15 Expressão Gênica............................................................................ 86

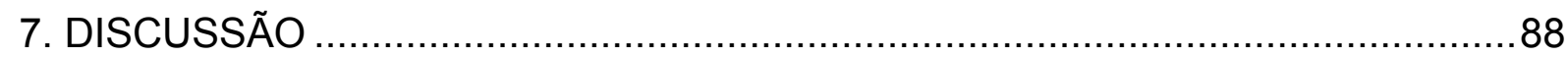

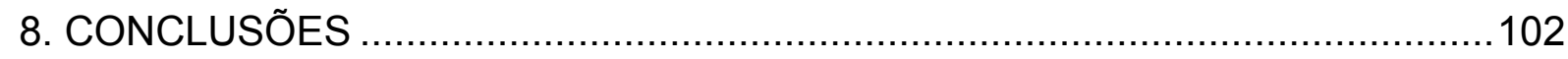

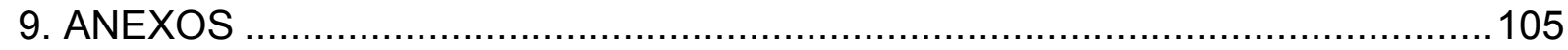

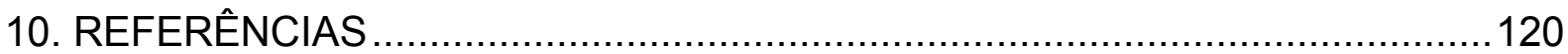




\section{LISTA DE ABREVIATURAS}

ACTH Hormônio adrenocorticotrófico

CAR Receptor constitutivo androstano

DBD Domínio de ligação ao DNA amino-terminal

DDS Distúrbio do desenvolvimento sexual

DHEA Deidroepiandrosterona

DHEAS Sulfato de Deidroepiandrosterona

DHT Dihidrotestosterona

FAD Domínio flavina adenina dinucleotídeo

FMN Domínio flavina mononucleotídeo

Grupo A Pacientes carreadoras de mutações no gene CYP21A2 que conferem $<2 \%$ de atividade residual da $210 \mathrm{H}$

Grupo B Pacientes carreadoras de mutações no gene CYP21A2 que conferem 3 a $7 \%$ de atividade residual da $210 \mathrm{H}$

HAC Hiperplasia Adrenal Congênita

HLA Antígenos leucocitários humanos

HSD Hidroxiesteróide dehidrogenase

IVS Região intrônica

LBD Domínio de ligação ao ligante carboxi-terminal

LR Grandes rearranjos gênicos

NADPH Fosfato de nicotinamida adenina dinucleotídeo reduzido

NTD Domínio amino-terminal

nCAG Número de repetições do trinucleotídeo CAG

$\mathrm{pb} \quad$ Pares de base nucleotídicas

PCR Reação em cadeia da polimerase

Pdiol 5a-pregnane-3a,17a-diol-20-one

POR P450 óxido-redutase

PS Forma clássica perdedora de sal

PXR Receptor $X$ pregnano

P450 Citocromos que absorvem a luz no comprimento de onda de $450 \mathrm{~nm}$ no estado reduzido complexado com monóxido de carbono 


$\begin{array}{ll}\text { RNAm } & \text { Ácido ribonucleico mensageiro } \\ \text { SNP } & \text { Polimorfismo de um único nucleotídeo } \\ \text { SOP } & \text { Síndrome dos ovários policísticos } \\ \text { SRD5A2 } & \text { Gene da } 5 \text { alpha-redutase tipo } 2 \\ \text { T } & \text { Testosterona } \\ \text { VS } & \text { Forma clássica virilizante simples } \\ \text { 17OHP } & \text { 17-hidroxi-progesterona } \\ 210 H & \text { enzima da esteroidogênese 21-hidroxilase }\end{array}$




\section{LISTA DE FIGURAS}

Figura 1. Esteroidogênese no córtex da adrenal.

Figura 2. A: Diferenciação normal da genitália feminina. B: Representação esquemática dos diferentes graus de virilização fetal da genitália feminina, quantificação usando a escala de Prader (I a V).

Figura 3. A: Diferenciação normal da genitália externa feminina. B: Representação esquemática dos diferentes graus de virilização fetal da genitália externa feminina, quantificação usando a escala de Prader (I a V).

Figura 4. Localização dos genes CYP21, dentro do locus dos genes do complexo principal de histocompatibilidade humana, no cromossomo 6 (6p21.3).

Figura 5. O lócus da família CYP3A localizado no cromossomo 7 (7q21-q22.1), contém quatro genes funcionais: CYP3A7, CYP3A4, CYP3A5 e CYP3A43 e três pseudogenes: CYP3AP1, CYP3AP2 e CYP3AP3.

Figura 6. Mecanismo de ação dos receptores nucleares PXR e CAR..

Figura 7. Representação esquemática da relação do POR com os citocromos P450 tipo II.

Figura 8. Mecanismo de ação dos andrógenos 40

Figura 9. Eletroforese em gel de agarose 3\%, corado com brometo de etídeo, dos produtos de digestão enzimática (enzima Rsal) para rastreamento do alelo V89L SRD5A2.. 
Figura 10. Gel de agarose 1\% mostrando a integridade da extração de RNA em amostras de pele genital de 3 pacientes.

Figura 11. Boxplot das concentrações basais de 170HP das pacientes com hiperplasia adrenal congênita de acordo com o genótipo $21 \mathrm{OH}$, grupos A e B.

Figura 12. Boxplot das concentrações basais de androstenediona de pacientes com hiperplasia adrenal congênita de acordo com o genótipo $210 \mathrm{H}$, grupos A e B

Figura 13. Boxplot das concentrações basais de testosterona das pacientes com hiperplasia adrenal congênita de acordo com o genótipo $21 \mathrm{OH}$, grupos A e B.

Figura 14. Boxplot do grau de virilização da genitália externa (Prader score I a V) das pacientes com hiperplasia adrenal congênita de acordo com o genótipo $210 \mathrm{H}$, grupos A e B.

Figura 15. Boxplot das concentrações basais de testosterona de acordo com o grau de virilização da genitália externa (Prader score I a V) nas pacientes com hiperplasia adrenal congênita. .71

Figura 16. Frequências das variantes A503V POR, -71G HSD17B5 e V89L SRD5A2 de acordo com o Prader score em pacientes com genótipo $210 \mathrm{H}$ do grupo A..........80

Figura 17. Frequências das variantes A503V POR, -71G HSD17B5 e V89L SRD5A2 de acordo com o Prader score em pacientes com genótipo $210 \mathrm{H}$ do grupo $\mathrm{B}$..........80

Figura 18. Distribuição do número de repetições CAG do gene receptor androgênico das pacientes com hiperplasia adrenal congênita de acordo com o genótipo $210 \mathrm{H}$. 
Figura 19. Distribuição do número de repetições $C A G$ do receptor androgênico de acordo com o Prader score de pacientes com hiperplasia adrenal congênita carreando genótipo $210 \mathrm{H}$ A.

Figura 20. Distribuição do número de repetições $C A G$ do receptor androgênico de acordo com o Prader score de pacientes com hiperplasia adrenal congênita carreando genótipo $210 \mathrm{H} \mathrm{B}$

Figura 21. Frequências do SNP 26: rs2307424 CAR e SNP 37: rs2518047 HSD17B5 de acordo com o Prader score em pacientes com genótipo $210 \mathrm{H}$ A e B junto.. 


\section{LISTA DE TABELAS}

Tabela 1. Dados clínicos e dosagens hormonais das pacientes com a forma clássica da hiperplasia adrenal congênita por deficiência da 21-hidroxilase. 106

Tabela 2. Dados clínicos e moleculares do gene CYP21A2 das pacientes com hiperplasia adrenal congênita cujo fragmento de pele genital foi obtido durante genitoplastia corretiva.

Tabela 3. Sequência nucleotídica dos primers do gene CYP3A7 e tamanho dos fragmentos amplificados.

Tabela 4. Sequência nucleotídica dos primers do gene $P X R$ e tamanho dos fragmentos amplificados.

Tabela 5. Sequência nucleotídica dos primers do gene CAR e tamanho dos fragmentos amplificados.

Tabela 6. Sequência nucleotídica dos primers dos genes SRD5A2, HSD17B5, POR, $R A$ e tamanho dos fragmentos amplificados.

Tabela 7. Tabela dos genes endógenos e alvos estudados na expressão tecidual em pele genital.

Tabela 8. Grau de virilização da genitália externa de pacientes com hiperplasia adrenal congênita nos genótipos mais frequentes da $210 \mathrm{H}$

Tabela 9. Pacientes portadores de mutações novas no gene CYP21A2 de acordo com a forma clínica da hiperplasia adrenal congênita e com o grau de virilização da genitália externa. 
Tabela 10. Frequência das variantes encontradas no gene CYP3A7 das pacientes com hiperplasia adrenal congênita e na população caucasiana.

Tabela 11. Frequência das variantes do gene $P X R$ em 91 pacientes com hiperplasia adrenal congênita e na população caucasiana. 73

Tabela 12. Frequência das variantes do gene $C A R$ em 91 pacientes com hiperplasia adrenal congênita e na população caucasiana.

Tabela 13. Variantes dos genes CYP3A7, PXR e CAR, com frequência alélica maior do que $2 \%$, distribuídas de acordo com os grupos genotípicos $210 \mathrm{OH}(\mathrm{A}$ e $\mathrm{B})$, forma clínica e com o grau de virilização genital.

Tabela 14. Regressão linear uni-variada do genótipo $210 \mathrm{OH}$ e dos SNPs dos genes CYP3A7, PXR e CAR com o Prader score como variável dependente.

Tabela 15. Regressão linear uni-variada dos SNPs do gene CYP3A7 em cada grupo genotípico $210 \mathrm{H}$ ( $\mathrm{A}$ e B), com o Prader score como variável dependente.

Tabela 16. Regressão linear uni-variada dos SNPs dos genes $P X R$ e CAR em cada grupo genotípico $210 \mathrm{OH}$ (A e B), com o Prader score como variável dependente. ....77

Tabela 17. Distribuição das variantes encontradas nos genes $P O R, H S D 17 B 5 \mathrm{e}$ SRD5A2 de acordo com o genótipo $210 \mathrm{H}$, forma clínica e com o grau de virilização nas pacientes com hiperplasia adrenal congênita.

Tabela 18. Frequências dos alelos curtos e longos do nCAG do gene receptor androgênico de acordo com o Prader score nas pacientes com hiperplasia adrenal congênita divididas nos grupos genotípicos A e B 
Tabela 19. Regressão linear uni-variada das variantes encontradas nos genes $P O R$, HSD17B5, SRD5A2 e alelo curto e longo nCAG RA com o Prader score como variável dependente.

Tabela 20. Análise de regressão linear uni- variada das variantes encontradas nos genes POR, HSD17B5, SRD5A2 e alelo curto e longo nCAG RA de acordo com os grupos genotípicos A e B

Tabela 21. Casos discordantes entre os genótipos $210 \mathrm{H}$ e o grau de virilização genital em mulheres com hiperplasia adrenal congênita.

Tabela 22. Expressão dos genes HSD17B5, SRD5A1, SRD5A2 e RA no tecido de pele genital das 12 pacientes com hiperplasia adrenal congênica 


\section{RESUMO}

Kaupert LC. Análise de genes moduladores do fenótipo de virilização genital em mulheres com a forma clássica da deficiência da 21-hidroxilase [tese]. São Paulo: Faculdade de Medicina, Universidade de São Paulo; 2012.

A hiperplasia adrenal congênita (HAC) por deficiência da enzima 21-hidroxilase $(210 H)$ é uma doença autossômica recessiva que compromete a síntese de cortisol e/ou aldosterona. É a causa mais frequente de distúrbio da diferenciação sexual 46,XX. Apresenta uma diversidade fenotípica, a qual é decorrente de mutações no gene CYP21A2. Observa-se forte correlação do comprometimento da atividade enzimática predita pelo genótipo com a forma de apresentação clínica e com os valores hormonais; entretanto, esta correlação não é observada com o grau de virilização pré-natal da genitália externa em mulheres com a forma clássica. Supomos que variações inter-individuais na ação, síntese e metabolismo dos andrógenos possam influenciar o fenótipo da virilização. Objetivos: avaliar se variantes alélicas em genes relacionados a ação, síntese ou metabolismo de andrógenos na vida fetal possuem um efeito modulatório na variabilidade fenotípica da virilização genital em mulheres com a forma clássica carreando genótipos $210 \mathrm{H}$ semelhantes. Também serão avaliadas se diferenças na expressão tecidual local dos genes HSD17B5, SRD5A1, SRD5A2 e RA influenciariam esta variabilidade fenotípica da forma clássica. Casuística: foram selecionadas 187 mulheres com a forma clássica da HAC $210 \mathrm{H}$ provenientes de 4 centros médicos. Dados clínicos, hormonais e o grau de virilização genital foram obtidos de forma retrospectiva da análise de prontuários. A intensidade de virilização genital foi classificada de acordo com a escala de Prader (P) e as pacientes foram divididas em 4 grupos: P I+II, P III, $\mathrm{P}$ IV e P V. As pacientes também foram agrupadas de acordo com o genótipo $210 \mathrm{H}$ : grupo $A$ carreadoras de mutações que predizem $<2 \%$ de atividade enzimática residual $(n=122)$ e grupo $B$ carreadoras de mutações que predizem 3 a $7 \%$ de atividade residual $(n=58)$. Metodologias: foram amplificadas e re-sequenciadas as regiões que flanqueiam os exons dos genes CYP3A7, PXR e CAR. Para as variantes funcionais, foram re-sequenciados os exons $12-13$ do $P O R$ e a região 
promotora do HSD17B5. As variantes V89L e A49T do SRD5A2 foram rastreadas por PCR-RFLP e o nCAG do RA por eletroforese capilar e análise pelo GeneScan. A determinação da expressão gênica em pele genital foi feita por PCR em tempo real utilizando os genes endógenos CYC, PGK1 e B2M. Os testes t-test, Mann-Whitney, Kruskal-Wallis, Fisher e regressão linear uni- e múltipla foram utilizados na análise estatística. Resultados: o Prader score no genótipo A variou de II a V (III: III - IV) e no genótipo $\mathrm{B}$ de I a $\mathrm{V}$ (III: II - III) $(P<0,001)$. Foram encontradas em $2,5 \%$ dos alelos a variante $C Y P 3 A 7^{\star} 1 \mathrm{C}$, em 24\% CYP3A7*2, 31\% rs 2307424 CAR, 25\% A503V POR, 33\% -71G HSD17B5, 17\% rs2518047 HSD17B5, 31\% V89L SRD5A2 e em $1 \%$ dos alelos a variante $A 49 T$ SRD5A2. Foi identificada associação das variantes rs2307424 CAR $\left(P=0,023 ; r^{2}=0,253\right)$ e $r s 2518047$ HSD17B5 $\left(P=0,006 ; r^{2}=0,144\right)$ com o grau de virilização genital, tem sido encontradas em maior frequência no grupo de pacientes com virilização mais intensa. Todas as outras variantes não apresentaram associação com o Prader score $(P>0,05)$. As diferenças de expressão de todos os genes analisados em amostras de pele genital não foram estatisticamente significantes ( $P>0,05$ ), embora observou-se que em $4 / 7$ amostras de pacientes com Prader score IV houve uma super-expressão do gene SRD5A2 em relação a 1/5 pacientes com Prader score III. Conclusão: neste estudo multicêntrico observamos que o genótipo $210 \mathrm{H}$ se correlacionou com a intensidade de virilização genital em mulheres com a forma clássica. A variante rs2307424 do gene CAR, relacionada ao metabolismo pré-natal de andrógenos, e a variante rs2518047 do gene $H S D 17 B 5$, relacionada à síntese de testosterona, associaram-se à fenótipos de virilização mais intensos. Não identificamos diferenças na expressão tecidual dos genes relacionados à síntese e/ou ação periférica de andrógenos em pacientes com os diferentes graus de virilização.

Descritores: 1. Hiperplasia supra-renal congênita 2. Virilismo 3. Polimorfismo genético 4. Expressão gênica. 


\section{SUMMARY}

Kaupert LC. Analysis of modulatory factors involved in the phenotype of external genitalia virilization in females with classical form of 21-hydroxylase deficiency [thesis]. São Paulo: "Faculdade de Medicina, Universidade de São Paulo"; 2012.

Congenital Adrenal hyperplasia ( $\mathrm{CAH})$ due to 21-hydroxylase deficiency $(21 \mathrm{OH})$ is an autosomic recessive disorder characterized by an impairment in the cortisol and/or aldosterone synthesis, being the most frequent cause of $46, \mathrm{XX}$ disorder of sex development. The disease presents a wide phenotypic variability resulting from different CYP21A2 gene mutations and a strong correlation has been observed among genotypes, clinical forms and basal hormone levels. However, this correlation is not observed regarding the degree of prenatal external genitalia virilization in females and an interindividual variability in the synthesis, metabolism and/or peripheral action of androgens could corroborate for these findings. Objectives: to evaluate if allelic variants in genes related to the androgen synthesis, metabolism and peripheral action could modulate the genital phenotype in $\mathrm{CAH}$ females bearing similar CYP21A2 mutations. Differences in the HSD17B5, SRD5A1, SRD5A2 and RA gene expression in genital skin were evaluated among patients with different degrees of external genital virilization. Patients: were selected $187 \mathrm{CAH}$ females and clinical and hormonal data were retrospectively evaluated. The degree of external genitalia virilization was classified according to Prader $(P)$ scores and patients were divided into 4 groups: P I+II, P III, P IV and P V. Patients were also grouped according to $210 \mathrm{H}$ genotypes: group $A$ bearing mutations predicting $<2 \%$ of residual enzymatic activity $(n=122)$ and group $B$ between 3 to $7 \%(n=58)$. Methodology: the exonic flanking regions of CYP3A7, PXR e CAR genes were PCR amplified and sequenced. The exons $12-13$ of $P O R$ and the promotor region of HSD17B5 were sequenced to screen the functional polymorphisms. The V89L and A49T SRD5A2 alleles were screened by PCR-RFLP and the CAG polymorphic tract of $A R$ gene by capillary electrophoresis and GeneScan analysis. The differential gene expression in genital skin was evaluated by real time PCR and the CYC, PGK1 e B2M housekeeping genes were used. The t-test, Mann-Whitney, Kruskal-Wallis, Fisher and uni- and 
multiple linear regression tests were used in statistical analysis. Results: Prader score in group A varied from II to V (III: III - IV) and in group B from I to V (III: II - III) $(P<0,001)$. The CYP3A7*1C allele was identified in $2.5 \%$ of alleles, CYP3A7*2 in $24 \%, r s 2307424$ CAR in 31\%, A503V POR in 25\%, -71G HSD17B5 in $33 \%$, rs 2518047 HSD17B5 in 17\%, V89L SRD5A2 em 31\% and A49T SRD5A2 in $1 \%$ of alleles. The $r s 2307424 C A R\left(P=0.023 ; r^{2}=0.253\right)$ and $r s 2518047$ HSD17B5 variants $\left(P=0.006 ; r^{2}=0.144\right)$ were associated with the degree of external genitalia virilization, and they were found in a higher frequency in more virilized patients. The remaining variants were not associated with Prader scores ( $P>0.05)$. The HSD17B5, $S R D 5 A 1, S R D 5 A 2$ and $R A$ gene expressions did not significantly differ between patients presenting Prader score III and IV ( $P>0.05)$; however, 4/7 samples from patients with Prader IV and just 1/5 patients with Prader III presented an increased SRD5A2 expression. Conclusion: In this multicentric study the $210 \mathrm{H}$ genotypes were correlated with the degree of external genitalia virilization in $\mathrm{CAH}$ females. The rs2307424 CAR and the rs2518047 HSD17B5 variants, related to the prenatal androgen metabolism and synthesis, respectively, explained some of the interindividual variability of genital phenotype in $\mathrm{CAH}$ females bearing similar CYP21A2 mutations. Differences in the expression of genes involved in the peripheral androgen action did not corroborate for the variability of genital phenotype in $\mathrm{CAH}$.

Descriptors: 1. Congenital adrenal hyperplasia 2. Virilism 3. Genetic polymorphism 4. Gene expression. 


\section{INTRODUÇÃO}




\subsection{Hiperplasia Adrenal Congênita por Deficiência da 21-Hidroxilase}

A hiperplasia adrenal congênita (HAC) é o nome dado à um grupo de doenças autossômica recessivas que afetam a síntese do cortisol; sendo decorrente da deficiência da enzima 21-hidroxilase $(210 \mathrm{H})$ em $90-95 \%$ dos casos. Esta deficiência enzimática é a causa mais frequente de genitália ambígua ao nascimento. A diminuição da atividade da $210 H$ prejudica a produção do cortisol, causando uma elevação crônica do hormônio adrenocorticotrófico (ACTH), resultando em hiperplasia do córtex da adrenal e em excesso da produção dos precursores do cortisol. Estes precursores são desviados para a síntese dos andrógenos adrenais e causam os sinais de virilização característicos desta doença (Figura 1) (White \& Speiser 2000). 


\section{Mineralocorticóides Glicocorticóides Androgênios}

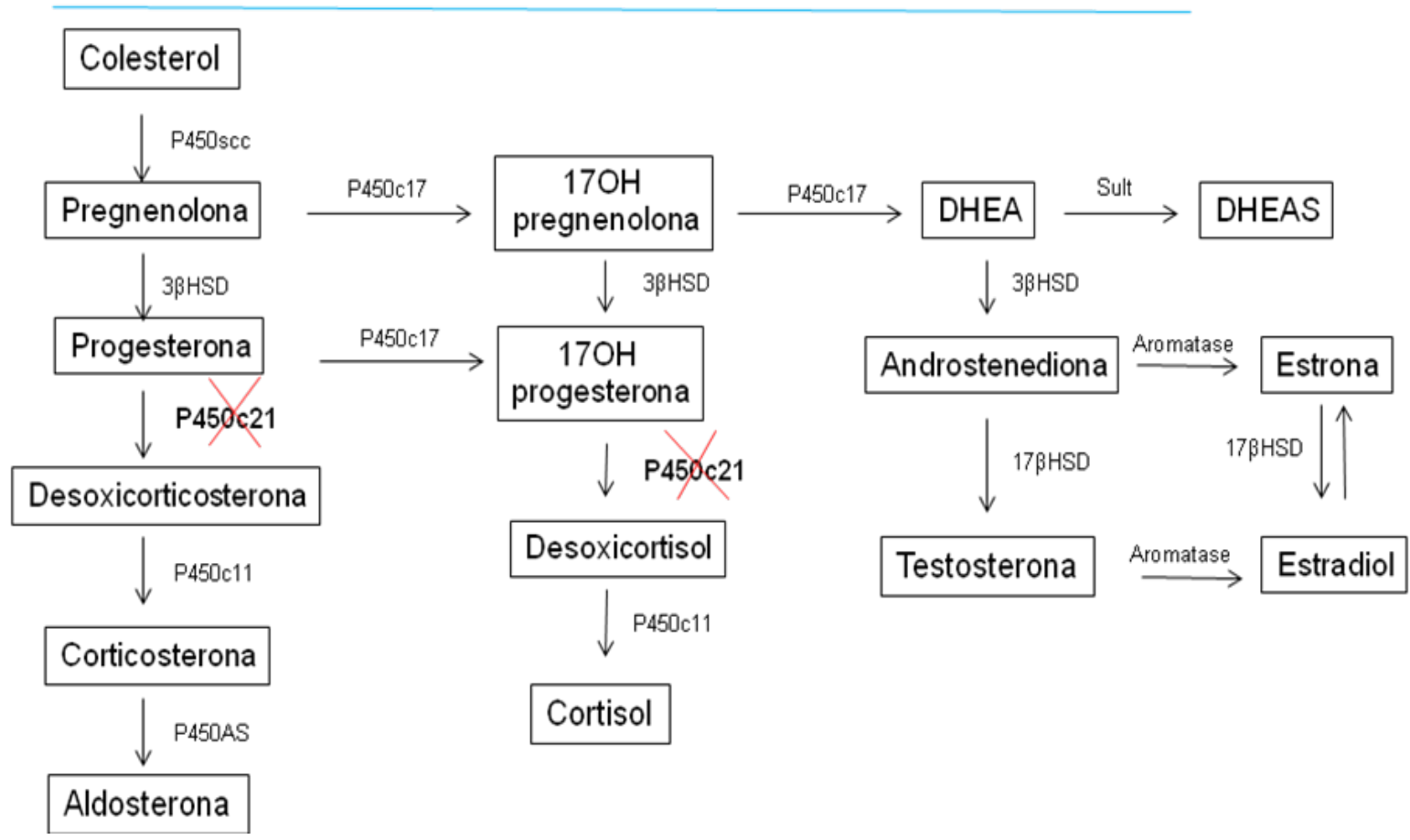

Figura 1. Esteroidogênese no córtex da adrenal. A deficiência da atividade da 21-hidroxilase (P450c21) compromete a síntese de cortisol e/ou aldosterona, ocorre aumento dos precursores do cortisol que são desviados para a produção de testosterona. DHEA: deidroepiandrosterona, DHEAS: sulfato de deidroepiandrosterona, P450scc: enzima de clivagem da cadeia lateral do colesterol,

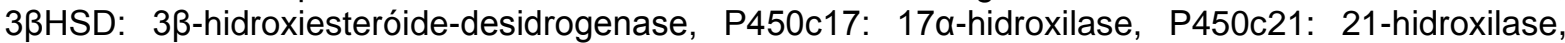
P450c11: 11ß-hidroxilase, P450AS: aldosterona-sintase, 17ßHSD: 17ß-hidroxiesteróidedesidrogenase.

A HAC 210 possui uma forma clínica mais branda, a forma não clássica e uma mais grave, a forma clássica. A forma não clássica é subdividida em assintomática e sintomática, cujo início das manifestações ocorrem mais tardiamente. A forma clássica é subdividida em virilizante simples e perdedora de sal (Witchel \& Azziz 2011).

A forma clássica virilizante simples caracteriza-se por graus variados de virilização pré-natal da genitália externa no sexo feminino, decorrente da exposição do feto feminino a um excesso de andrógenos entre a sexta e décima semana de gestação (Mercè Fernández-Balsells et al 2010). Na prática clínica o grau de 
virilização genital é quantificado por uma escala de cinco estádios, desenvolvida por Prader (1954): Prader I indica aumento isolado do clitóris; Prader II, aumento do clitóris com fusão posterior dos grandes lábios, mantendo-se individualizadas no períneo as aberturas uretral e vaginal; Prader III, aumento do clitóris associado à fusão posterior dos grandes lábios com abertura do seio urogenital (fusão da uretra e vagina) no períneo; Prader IV, aumento do clitóris com abertura do seio urogenital na base do clitóris e fusão completa dos grandes lábios; Prader V, fusão labial completa e abertura do seio urogenital na extremidade do clitóris aumentado, semelhante a uma genitália masculina normal (Figuras 2 e 3).

A
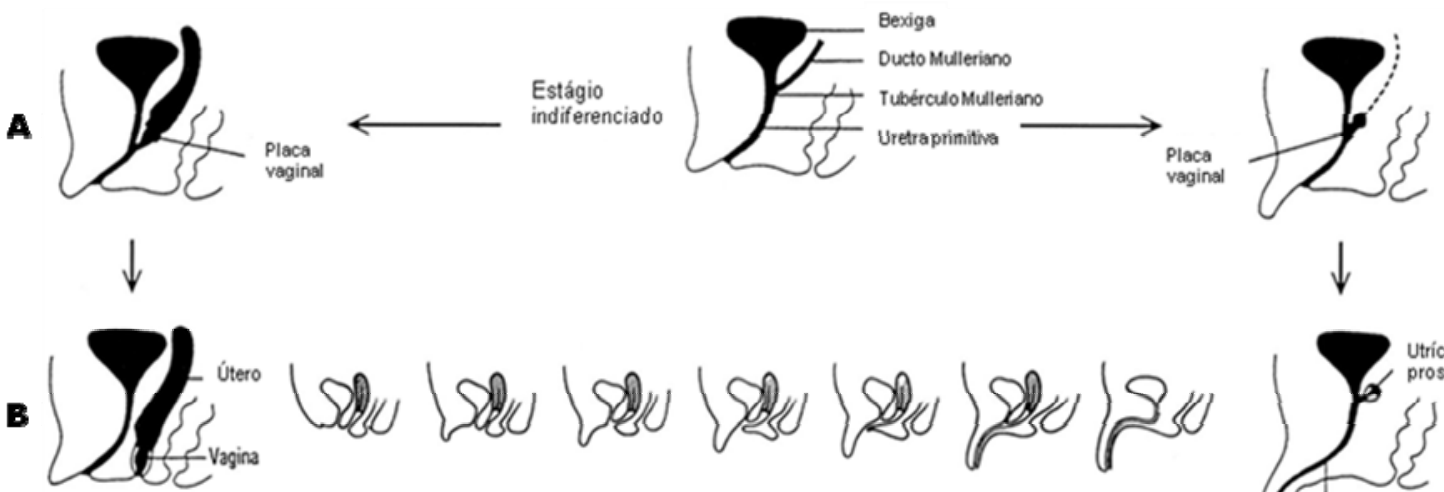

Normal \& 1

2

Feminino

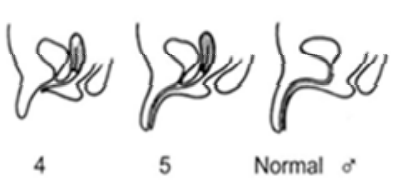




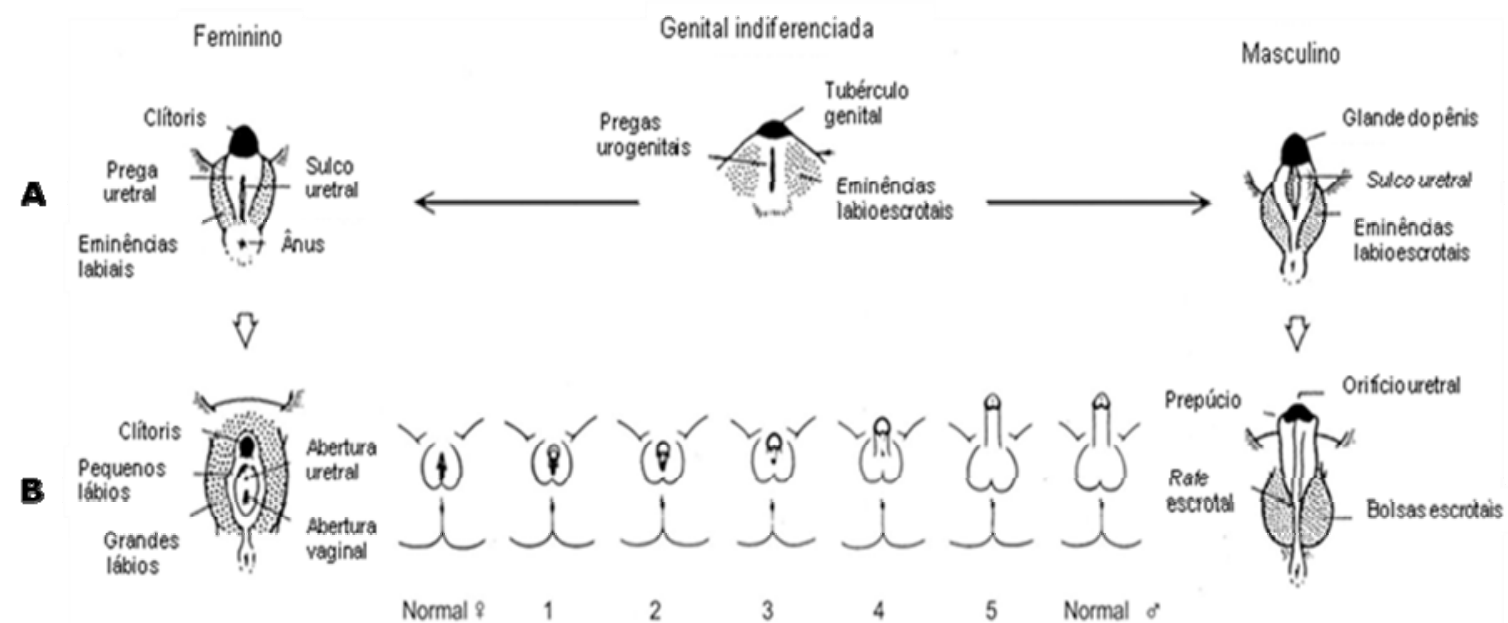

Figura 3. A: Diferenciação normal da genitália externa feminina. B: Representação esquemática dos diferentes graus de virilização fetal da genitália externa feminina, quantificação usando a escala de Prader (I a V).

Na vida pós natal, ambos os sexos, sem tratamento adequado, desenvolverão virilização, caracterizada por aumento do clitóris ou pênis, pubarca precoce, aumento da massa muscular e aumento da velocidade de crescimento com acentuado avanço da idade óssea, resultando em baixa estatura final (White \& Speiser 2000).

A forma perdedora de sal, além dos sinais de virilização pré e pós-natais que ocorrem na forma virilizante simples, também caracteriza-se por maior comprometimento na síntese de aldosterona, o que resulta em desidratação com hiponatremia e hiperpotassemia. Geralmente esta desidratação ocorre antes dos trinta dias de vida e, quando não tratada, leva ao choque e óbito (White \& Speiser 2000).

A prevalência da forma clássica em nossa população é de 1 em cada 10.300 nascidos-vivos, mas pode variar consideravelmente entre os diferentes grupos 
étnicos (Hayashi et al 2011). A forma não clássica tem prevalência mais alta, afetando de 0,6 a 9\% de mulheres com hiperandrogenismo (Witchel \& Azziz 2010).

A anormalidade bioquímica mais evidente nos pacientes com $\mathrm{HAC} 21 \mathrm{OH}$ é a elevação da $170 \mathrm{H}$-progesterona (17OHP), o principal substrato da enzima, que geralmente está em concentrações séricas superiores a $50 \mathrm{ng} / \mathrm{mL}$ na forma clássica. Na forma não clássica as concentrações basais da 17OHP podem estar elevadas ou normais. Outros hormônios que também estão elevados em pacientes não tratados são: progesterona, androstenediona e testosterona (Bachega et al 2004).

Conforme exposto acima, observa-se que pacientes com a deficiência da 21hidroxilase apresentam um espectro variável na atividade enzimática residual, resultando na apresentação de formas clínicas com diferentes gravidades, as quais podem ser justificadas pela presença de diversas mutações no gene CYP21A2 (Speiser et al 1992, Wedell et al 1994, Krone et al 2000, Finkielstain et al 2011).

\subsection{Genética Molecular da Hiperplasia Adrenal Congênita por Deficiência da 21- Hidroxilase}

A enzima $210 H$ é codificada pelo gene CYP21A2, localizado no cromossomo 6 (6p21.3), dentro do locus dos genes que codificam o complexo principal de histocompatibilidade, especificamente na região HLA classe III (Dupont et al 1977). A unidade CYP21 está duplicada, sendo o CYP21A2 o gene ativo e o CYP21A1P o pseudogene, que contém várias mutações deletérias que o tornam não funcionante (White et al 1986) (Figura 4). 


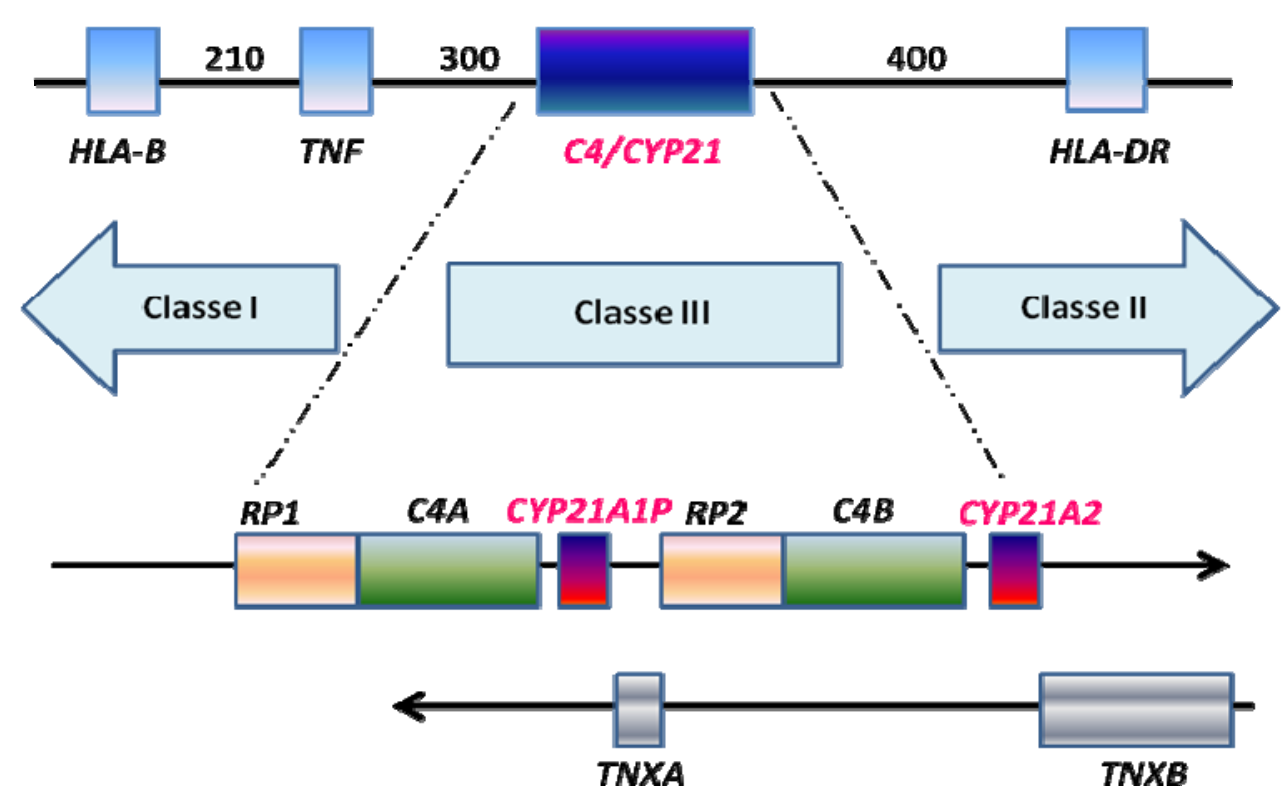

Figura 4. Localização dos genes CYP21, dentro do locus dos genes do complexo principal de histocompatibilidade humana, no cromossomo 6 (6p21.3). Os números identificam as distâncias entre genes em quilopares de bases. Abaixo: Mapa da região ao redor dos genes da 21-hidroxilase (CYP21). O pseudogene é identificado como CYP21A1P e o gene ativo CYP21A2. C4A e C4B, genes do quarto componente do complemento sérico (fator $\mathrm{C} 4$ ). RP1, gene de uma proteína quinase nuclear; RP2, uma cópia truncada deste gene; TNXB, gene da Tenascina-X; TNXA, uma cópia truncada deste gene. Os genes TNX estão em fitas cromossômicas opostas e as setas indicam o sentido da transcrição. Adaptado de White \& Speiser 2000.

Os genes CYP21A2 e CYP21A1P tem 98\% de homologia entre as regiões exônicas e 96\% entre as regiões intrônicas. Este extremo grau de identidade entre os nucleotídeos favorece o emparelhamento desigual entre os genes homólogos durante a meiose, predispondo o aparecimento de mutações no gene ativo. Estas mutações incluem deleções, grandes conversões gênicas, as quais consistem de rearranjos entre grandes segmentos na sequência da unidade CYP21 ou microconversões e pequenos rearranjos, que são as mutações de ponto (Higashi et al 1988, Tusie-Luna et al 1990).

Do ponto de vista didático, Speiser et al (1992) dividiram as mutações em três grupos de acordo com o comprometimento enzimático observado em estudos de 
mutagênese e expressão in vitro (Tusié-Luna et al 1990, Higashi et al 1991). O grupo $A$, pode também ser subdividido em sub-grupos $A 1$ e $A 2$. O subgrupo A1 inclui as mutações que abolem a atividade enzimática, tais como deleções do CYP21A2, grandes conversões gênicas, IVS2-2A>G, deleção de 8 nucleotídeos (p.G110Efs), p.Ser170fs (c.511_512insA), exon 6 cluster (p.I236N, p.V237E, p.M239K), p.Leu307fs (c.923_924insT), p.G291S, p.Q318X, p.R356W, p.R408C e p.G424S. O subgrupo $\mathrm{A} 2$ inclui as mutações que conferem $<2 \%$ de atividade residual da $210 \mathrm{H}$, como a mutação IVS2-13A/C>G (I2 splice). O grupo B é caracterizado pelas mutações p.I172N e p.R426H, que conferem de 3 a $7 \%$ de atividade residual enzimática. As mutações que atribuem mais do que $20 \%$ de atividade residual, são incluídas no grupo C (Speiser et al 1992, Bachega et al 1998, Finkielstain et al 2011).

O grande número de pacientes com HAC permite correlacionar os diferentes genótipos com as formas clínicas; em geral, os pacientes homozigotos para as mutações do grupo $A$ (genótipos A1/A1, A1/A2 ou A2/A2) apresentam fenótipo da forma clássica perdedora de sal, homozigotos para as mutações do grupo B (genótipo B/B) ou ainda em heterozigose composta com as do grupo A (genótipo A/B) manifestam a forma clássica virilizante simples. Indivíduos homozigotos para mutações do grupo $\mathrm{C}$ ou em heterozigose composta com as mutações do grupo $\mathrm{A}$ ou B, exibem fenótipo da forma não clássica (Speiser et al 1992, Bachega et al 2004).

A literatura tem descrito uma forte correlação entre o genótipo da $210 \mathrm{H}$ com a severidade da forma clínica e com os valores hormonais ao diagnóstico da 170HP e de andrógenos (Bachega et al 1998, Paulino et al 1999, Witchel et al 2000, Torres et 
al 2003, Costa Barbosa et al 2010). Entretanto, não se observa esta mesma correlação do genótipo com a intensidade de virilização da genitália externa em meninas com a forma clássica. Meninas carreando o genótipo do grupo A tendem a ter um grau de virilização genital maior do que as carreando o do grupo B; porém, existe uma grande sobreposição deste grau de virilização genital entre os dois grupos (Giwercman et al 2002, Rocha et al 2008).

Contudo, os fatores que podem influenciar a intensidade da virilização genital ainda não estão esclarecidos; por isso, torna-se importante a análise de mecanismos que poderiam explicar estas diferenças fenotípicas, as quais ajudarão no melhor entendimento da fisiopatologia da $\mathrm{HAC} 210 \mathrm{H}$.

$\mathrm{Na}$ literatura, apenas três estudos avaliaram de forma detalhada a variabilidade fenotípica da genitália externa em meninas com a forma clássica e sugeriram que variantes genéticas, não relacionadas ao lócus CYP21, poderiam estar modulando o fenótipo (Giwercman et al 2002, Rocha et al 2008, Welzel et al 2010). Hipotetizamos que variantes em genes relacionados ao metabolismo ou ação periférica androgênica poderiam modular o fenótipo genital de meninas com HAC no período fetal. 


\subsection{Genes Relacionados com a Metabolização Androgênica Fetal}

\subsubsection{CYP3A7}

A família CYP3A representa mais de $50 \%$ de todos os citocromos expressos no fígado e são clinicamente importantes, tanto para o metabolismo da maioria dos fármacos conhecidos, como para manter a homeostase das concentrações circulantes de esteróides, incluindo os andrógenos (Lamba et al 2002).

A família CYP3A é composta por quatro genes funcionais: CYP3A7, CYP3A4, CYP3A5, CYP3A43 e por três pseudogenes adjacentes: CYP3AP1, CYP3AP2 e CYP3AP3 (Figura 5).

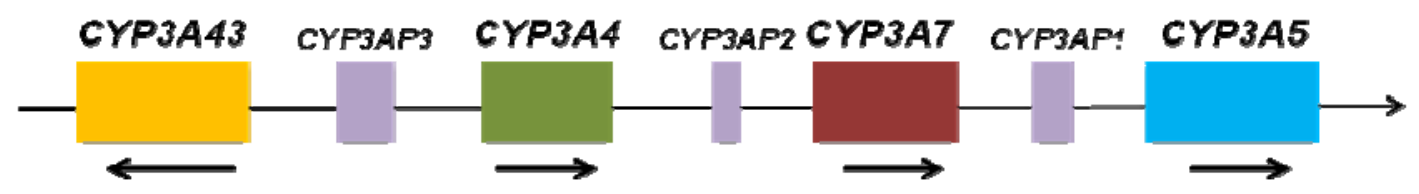

Cromossomo 7

Figura 5. O lócus da família CYP3A localizado no cromossomo 7 (7q21-q22.1), contém quatro genes funcionais: CYP3A7, CYP3A4, CYP3A5 e CYP3A43 e três pseudogenes: CYP3AP1, CYP3AP2 e CYP3AP3. As flechas indicam o sentido da transcrição. Adaptado de Lamba et al 2002.

A expressão das enzimas CYP3As (CYP3A4, CYP3A5 e CYP3A7) é regulada de maneira diferente durante o desenvolvimento, pré e pós-natal. O gene CYP3A4 embora represente 30 a $50 \%$ do conteúdo hepático dos CYPs em adultos, na vida fetal possui uma expressão muito baixa, bem como a do gene CYP3A43. O gene CYP3A5 inicia a expressão na vida fetal e continua na vida adulta. Para este gene 
foi descrita uma variante alélica frequente no íntron 3 (alelo $C Y P 3 A 5^{\star} 3$ ), que resulta na ausência da proteína.

O gene CYP3A7 é o CYP mais expresso no fígado fetal (> 90\%), e a sua expressão começa com 50 a 60 dias de gestação, coincidindo com o período de formação genital, e continua por até 6 meses de idade pós-natal (Leeder et al 2005, Rodriguez-Antona et al 2005a).

O CYP3A7 tem um importante papel na metabolização de esteróides adrenais e gonadais, tal como a deidroepiandrosterona (DHEA), seu sulfato (DHEAS) e a testosterona (T). Este citocromo cataliza a reação de 16a-hidroxilação da DHEA e DHEAS, tornando-os menos ativos e mais fáceis de serem eliminados da circulação sanguínea.

Recentemente, foi descrita a expressão do gene CYP3A7 em fígado e intestino em adultos, esta expressão tardia foi associada ao alelo $C Y P 3 A 7^{*} 1 C$ (Burk et al 2002). Este alelo tem uma substituição de 60 pares de bases ( $p b)$ na região promotora, resultado de transferência da sequência do gene CYP3A4. Estudos demonstraram que este alelo em indivíduos normais ou com doença hiperandrogênica, como a Síndrome dos Ovários Policísticos (SOP), associa-se com uma redução de até $50 \%$ nas concentrações séricas de DHEAS e de testosterona total (Smit et al 2005, Goodarzi et al 2008a).

Destacamos também o alelo $C Y P 3 A 7^{\star 2} 2$, que possui a substituição Treonina pela Arginina na posição 409 do exon 11 e é associado à maior capacidade de hidroxilação da DHEA em relação ao alelo selvagem (Rodriguez-Antona et al 2005a). 
O alelo $C Y P 3 A 7^{*} 2$ está em desequilíbrio de ligação com uma variante encontrada no íntron 1 do pseudogene CYP3AP1, que confere um splicing alternativo, incorporando dois exons do pseudogene para o gene ativo CYP3A7, resultando na proteína CYP3A7.1L. Apesar da adição dos dois exons causar um frame shift, a nova enzima continua sendo funcional, porém confere mudanças no padrão de hidroxilação da DHEA (Rodriguez-Antona et al 2005b). A frequência da variante $C Y P 3 A 7^{*} 2$, assim como da proteína CYP3A7.1L, diferem entre as populações, sendo encontradas em $7 \%$ dos caucasianos e em $60 \%$ dos africanos (Rodriguez-Antona et al 2005b).

A expressão e a atividade catalítica dos genes CYP3As são muito variáveis entre os indivíduos, que pode ser atribuída à presença de polimorfismos em seus fatores de transcrição. Os principais fatores de transcrição responsáveis pela expressão do gene CYP3A7 na vida fetal são o PXR (NR1/2) e o CAR (NR1/3) (Vyhlidal et al 2006).

\subsubsection{Receptores nucleares}

A super-família de receptores nucleares regula a expressão de genes envolvidos no metabolismo, diferenciação, proliferação e reprodução em resposta a moléculas lipofílicas, como os hormônios esteróides (Vyhlidal et al 2006).

Os receptores nucleares apresentam uma estrutura comum: um domínio conservado de ligação ao DNA amino-terminal (DBD) e um domínio de ligação ao ligante carboxi-terminal (LBD). 
A ativação do PXR e CAR se inicia no citoplasma. Após a exposição ao seu ligante, formam um heterodímero com o receptor de ácido retinóico $(R X R)$ e o complexo passa para o núcleo ligando-se a elementos de resposta de receptores nucleares na região promotora de genes alvos (Pascussi et al 1999) (Figura 6).

Vyhlidal et al (2006) observaram uma correlação da expressão dos receptores nucleares PXR e CAR com a do gene CYP3A7 em fígado fetal, sugerindo que parte da variabilidade interindividual na atividade do CYP3A possa ser influenciada por uma variabilidade na expressão dos receptores nucleares.

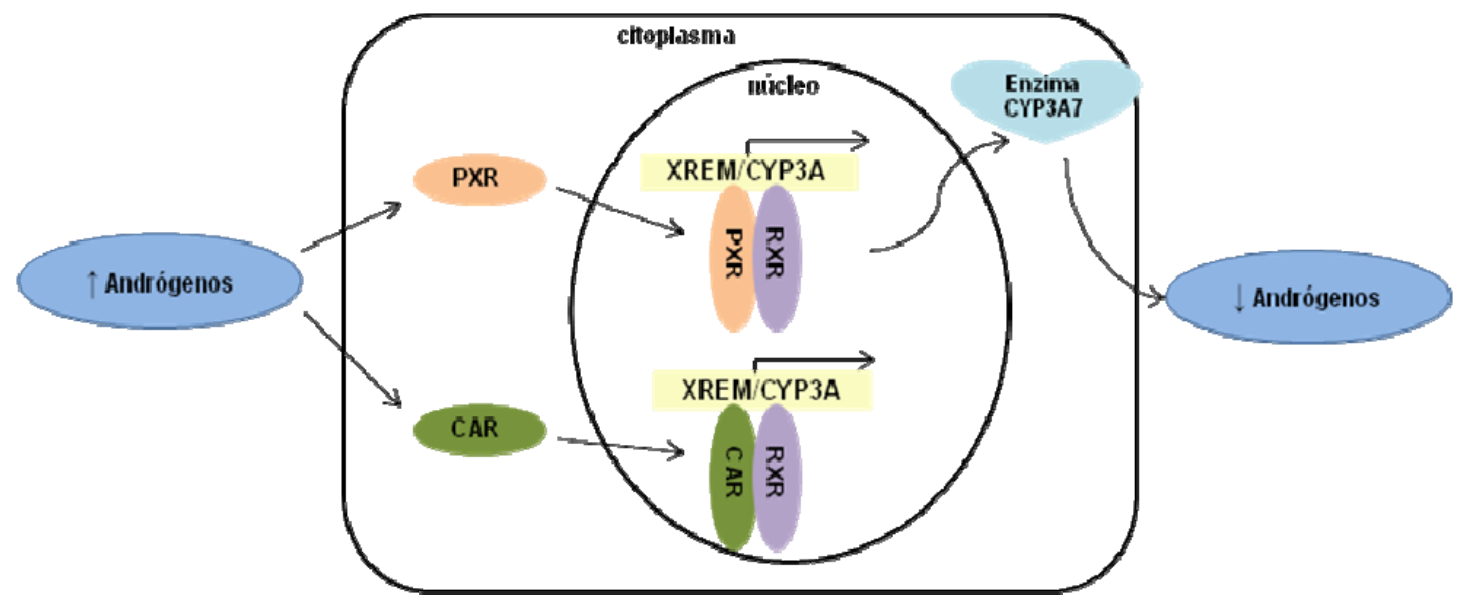

Figura 6. Mecanismo de ação dos receptores nucleares PXR e CAR. Com o aumento dos andrógenos na circulação sanguínea, os receptores se ligam aos hormônios e entram no núcleo, formando um heterodímero com o receptor nuclear RXR, ligando-se à região promotora XREM do gene CYP3A7. A enzima CYP3A7 metaboliza os hormônios, transformando-os em uma forma mais fácil de serem eliminados da circulação sanguínea. 


\subsubsection{Receptor Pregnano X}

O gene receptor pregnano $X(P X R)$, também conhecido como $N R 1 / 2$, está localizado no cromossomo 3 (3q12-13.3). Este gene consiste de 9 exons, sendo os exons 2 - 9 codificados (Zhang et al 2008).

Hustert et al (2001) identificaram 28 variantes no gene $P X R$, das quais seis eram missense e foram avaliadas in vitro para a indução da transativação do promotor do gene CYP3A4. As variantes localizadas na região DBD (E18K, P27S e G36R) não alteraram a indução; mas as variantes localizadas perto ou na região LBD (D163G, A370T e A370T) tiveram um efeito dramático na atividade de transativação do promotor do CYP3A4.

\subsubsection{Receptor Androstano Constitutivo}

O gene receptor androstano constitutivo $(C A R)$, também conhecido como NR1/3, está localizado no cromossomo 1 (1q23.3). Este gene consiste de 9 exons, com os exons 2 - 9 sendo codificados.

Ao contrário do gene $P X R$, que é amplamente estudado pela literatura, o gene CAR foi re-sequenciado apenas na população japonesa. Ikeda et al (2005) encontraram 26 variantes alélicas e quatro delas foram alterações missense, as quais foram selecionadas para estudos funcionais com o promotor do gene CYP3A4. Este estudo mostrou que as variantes H246R e L308P conferiram uma redução na transativação do gene alvo, sugerindo que estas modifiquem a transativação dos 
CYP3As. Por outro lado, as outras duas variantes V133G e N323S não apresentaram alterações na capacidade de transativação em relação ao alelo selvagem (lkeda et al 2005).

\subsection{Genes relacionados a biossíntese androgênica}

\subsubsection{P450 Óxido-Redutase}

O citocromo P450 óxido-redutase (POR) é uma flavoproteína doadora de elétrons necessária para a atividade de todos as enzimas microssomais P450 tipo II. O gene POR contém 15 exons e está localizado no cromossomo 7 (7q11.2).

A estrutura protéica do citocromo P450 óxido-redutase possui dois domínios distintos aceptores de elétrons, o domínio flavina adenina dinucleotídeo (FAD) e flavina mononucleotídeo (FMN), que transferem elétrons do NADPH para os citocromos P450 tipo II (Miller 2005) (Figura 7). 


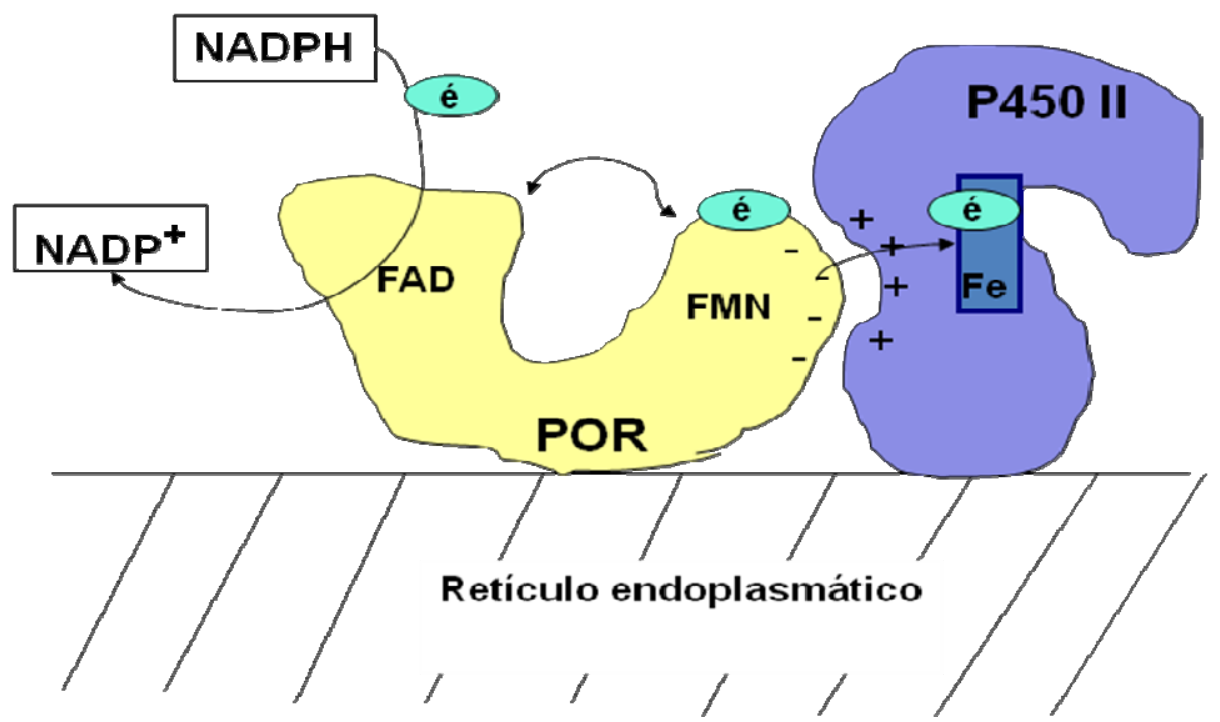

Figura 7. Representação esquemática da relação do POR com os citocromos $\mathrm{P} 450$ tipo II. Elétrons do NADPH reduzido passam para o domínio FAD, o POR muda sua estrutura conformacional e transfere os elétrons para o domínio FMN. O POR liga-se aos citocromos P450 tipo II por interações eletrostáticas e transfere os elétrons do domínio FMN para o grupo de ferro heme do P450, permitindo sua atividade catalítica. FAD: flavina adenina dinucleotídeo, FMN: flavina mononucleotídeo, NADPH: fosfato de nicotinamida adenina dinucleotídeo, POR: P450 óxidoredutase.

O POR transfere elétrons para três enzimas P450 tipo II da esteroidogênese: P450c17 (17a-hidroxilase/17,20 liase), P450c21 (21-hidroxilase) e P450aro (aromatase). Indivíduos com deficiência do POR tem um espectro de doenças esteroidogênicas, variando desde a presença de genitália ambígua e malformação óssea na infância à Síndrome dos Ovários Policísticos (SOP) em mulheres adultas (Huang et al 2008).

A literatura tem descrito muitas variantes no gene $P O R$ e foi demonstrado in vitro que algumas destas podem aumentar ou reduzir a eficiência catalítica das enzimas P450 tipo Il (Huang et al 2008). A variante mais comum do POR é a A503V, encontrada em $26 \%$ dos alelos em caucasianos. A A503V POR reduz a atividade catalítica da P450c17 em até 60\%, diminuindo a síntese androgênica (Huang et al 2008). 


\subsubsection{7ß-hidroxiesteróide-desidrogenase Tipo 5}

O grupo das enzimas 17ß-hidroxiesteróide-desidrogenase (17ßHSD) catalisam a redução do 17-keto (inativam) e/ou a oxidação do 17ß-hidroxiesteróides (ativam), tendo assim um importante papel no controle dos esteróides sexuais ativos, como a testosterona, diidrotestosterona (DHT), 5-androstenediol e estradiol nos tecidos alvos (Luu-The et al 2001).

As isoformas tipo 3 e 5 catalisam a formação de andrógenos, convertem a 4androstenediona em testosterona. A tipo 3 é expressa no tecido testicular e a sua deficiência em meninos causa distúrbio do desenvolvimento sexual (DDS) 46,XY, caracterizado por ambiguidade genital. Entretanto, em mulheres esta deficiência é assintomática (Mendonca et al 1999).

Nas adrenais, ovários e tecidos periféricos, a síntese androgênica é catalisada pela isoforma tipo 5. Portanto, esta enzima é a principal responsável pela produção de andrógenos em mulheres (Luu-The et al 2001).

O gene HSD17B5 está localizado no cromossomo 10 (10p 14.15), e possui 9 exons. Recentemente foi identificada uma variante na posição -71 da região promotora, que aumenta a ligação a fatores de transcrição, consequentemente aumenta também a expressão gênica e da atividade catalítica. $A$ variante $-71 \mathrm{G}$ foi observada em $34 \%$ dos alelos em caucasianos e tem sido associada ao aumento da testosterona plasmática em até 20\% em mulheres com SOP (Qin et al 2006). 


\subsection{Genes relacionados a ação periférica androgênica}

\subsubsection{Enzima 5 $\alpha-$ Redutase}

A enzima 5a-redutase possui duas isoformas, tipo 1 e 2 . O gene da isoforma tipo 1 é o $S R D 5 A 1$, localizado no cromossomo 5 (5p15.5) e o gene da isoforma tipo 2 é o SRD5A2, localizado no cromossomo 2 (2p23). Ambas convertem de maneira irreversível a testosterona em um substrato mais ativo, a diidrotestosterona (DHT) (Andersson et al 2001). A DHT é o andrógeno mais potente presente na circulação, tendo uma afinidade maior pelo receptor androgênico e aumentando em até 10 vezes a atividade de transativação em relação à da testosterona (Andersson et al 2001).

A isoenzima tipo 2 é predominantemente expressa nos tecidos reprodutivos masculinos, incluindo a vesícula seminal, epidídimo e próstata e a isoenzima tipo 1 é expressa em tecidos não reprodutivos, como o fígado e pele (Cheon 2011).

Dentre as variantes missense já descritas no gene $S R D 5 A 2$, que alteram a atividade catalítica da enzima, existem dois polimorfismos no exon 1, a substituição da valina no códon 89 pela leucina (V89L) e a substituição da alanina no codon 49 pela treonina (A49T). A variante mais frequente, em $30 \%$ dos alelos em caucasianos, é a V89L e Makridakis et al (1997) observaram in vitro que esta causa uma redução em $30 \%$ da atividade enzimática. A frequência da variante A49T é mais rara em todas as etnias, aproximadamente em $2 \%$ dos alelos, e aumenta em 5 vezes a atividade catalítica na conversão da testosterona para DHT.

Apesar da literatura não ser concisa, as duas variantes são associadas com doenças hiperandrogênicas; a variante V89L é associada com a diminuição do risco 
de câncer de próstata e SOP e com maior prevalência de hipospádia. A variante A49T é associada a um pior prognóstico para o câncer de próstata (Makridakis et al 1997, Thai et al 2005, Goodarzi et al 2006, Li et al 2003).

\subsubsection{Receptor Androgênico}

Os andrógenos tem a sua ação mediada através do receptor androgênico (RA), a DHT e em menor extensão a testosterona ligam-se ao receptor no citoplasma celular e o complexo migra para o núcleo para transativar genes alvos (Figura 8). Esta ação androgênica é tecido específica, sendo o $R A$ expresso em diversos tecidos, inclusive na pele genital (Gelmann 2002).

O gene $R A$ está localizado no cromossomo X $(\mathrm{Xq11-12)}$ e contém 8 exons. $\mathrm{O}$ primeiro exon codifica o domínio amino-terminal (NTD), região responsável pela regulação transcricional da proteína. Os exons 2 e 3 codificam o domínio de ligação ao DNA (DBD) e os exons 4 a 8 codificam a região carboxi-terminal (LBD). 


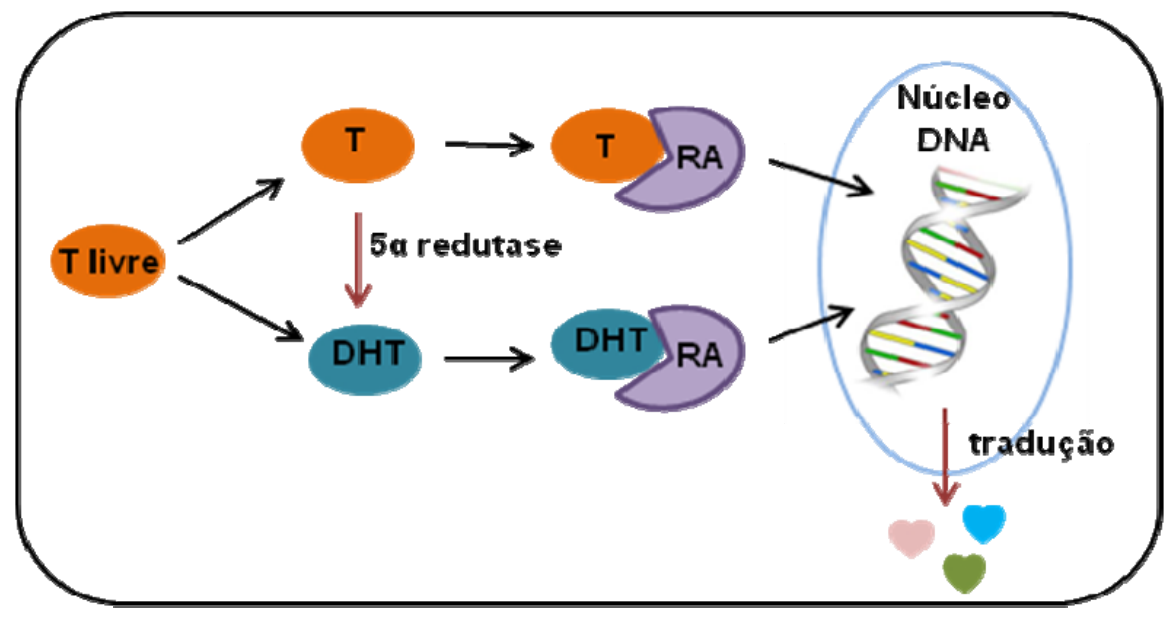

Figura 8. Mecanismo de ação dos andrógenos. A testosterona (T) e a dihidrotestosterona (DHT), após a catálise pela enzima $5 a-$ redutase tipos 1 e 2, ligam-se ao receptor androgênico (RA) para transativar genes alvos no núcleo celular.

O gene do $R A$ possui um trato polimórfico no exon 1 , repetições de glutamina (nCAG), variando na população normal de 11 a 31 repetições, sendo que $90 \%$ das mulheres são heterozigotas para este número de repetições (Kaupert et al 2010). Estudos in vitro identificaram que a atividade de transativação do RA possui correlação inversa com o número de repetições CAG (Chamberlain et al 1994, Tut et al 1997), consequentemente causa ganho ou diminuição de função.

O trato polimórfico CAG tem sido associado com o desenvolvimento de diferentes doenças andrógeno-dependentes. Um número maior do que 40 repetições causa diminuída atividade androgênica e correlaciona-se com o desenvolvimento de doença neurodegenerativa, a atrofia muscular espinhal-bulbar (La Spada et al 1997). Adicionalmente, alelos curtos ( $\leq 18$ repetições CAG) com ganho de função, estão associados com pubarca precoce idiopática, SOP e com maior agressividade do câncer de próstata e mama (Ibanez et al 2003, Kuasne et al 2010, Schüring et al 2012). 
2. JUSTIFICATIVA 
Meninas portadoras da forma clássica e carreadoras de mutações no gene CYP21A2 que predizem semelhante comprometimento da atividade enzimática apresentam grande variabilidade na virilização pré-natal da genitália externa. A literatura sugere que diferenças inter-individuais na sensibilidade periférica dos tecidos aos andrógenos e/ou no seu metabolismo poderiam ser responsáveis por esta diversidade fenotípica.

Entretanto, sabe-se que as diferenças inter-individuais na sensibilidade aos andrógenos pode ser mediada por variantes alélicas em genes relacionados a síntese, metabolismo e/ou ação androgênica. Recentes evidências demonstraram que polimorfismos nos genes CYP3A7, PXR, CAR, POR, HSD17B5, SRD5A1, SRD5A2 e RA influenciam o fenótipo de diversas doenças andrógeno-dependentes. Os dados expostos nos sugerem que variantes nos genes supracitados poderiam modular o fenótipo da forma clássica. Até o momento, apenas dois estudos avaliaram o efeito de variantes do RA no fenótipo genital de pacientes com HAC $210 \mathrm{H}$ e apresentaram resultados controversos; para a análise da influência dos demais genes ainda não existe trabalho na literatura. A identificação destas variantes pode contribuir para uma otimização individual da terapêutica na forma clássica. 
3. OBJETIVOS 


\subsection{Objetivo Geral}

Avaliar se fatores genéticos influenciam a variabilidade da virilização genital em mulheres com a forma clássica da hiperplasia adrenal congênita.

\subsection{Objetivos Específicos}

Correlacionar o grau de virilização genital de mulheres com a forma clássica da hiperplasia adrenal congênita com o comprometimento enzimático predito pelo genótipo do gene da 21-hidroxilase e com a presença de variantes em genes envolvidos:

- no metabolismo hepático de andrógenos na vida fetal (gene do citocromo P450 3A7 e de seus fatores de transcrição, CAR e PXR),

- na síntese de andrógenos (gene da enzima 17ß-hidroxiesteróide desidrogenase tipo 5 e do citocromo P450 óxido-redutase),

- na ação periférica de andrógenos (gene da enzima 5a-redutase tipos 1 e 2 e do receptor de andrógenos).

Avaliar se diferenças na expressão tecidual local dos genes SRD5A1, SRD5A2, HSD17B5 e RA se correlacionam com a intensidade da virilização genital em mulheres com a forma clássica da Hiperplasia Adrenal Congênita. 
4. CASUÍSTICA 
Este projeto foi aprovado pela Comissão de Ética para Análise de Projetos de Pesquisa (CAPPesq) da Diretoria Clínica do Hospital das Clínicas da Faculdade de Medicina da Universidade de São Paulo, Protocolo de Pesquisa n॰ 0149/08.

Selecionamos 187 mulheres com a forma clássica da hiperplasia adrenal congênita. O estudo foi realizado com uma casuística multicêntrica, 117 pacientes estão em seguimento clínico na Unidade de Endocrinologia do Desenvolvimento da Disciplina de Endocrinologia do Hospital das Clínicas de São Paulo (HCFMUSP), 52 na Universidade Estadual de Campinas (UNICAMP), 13 na Irmandade da Santa Casa da Misericórdia de São Paulo (ISCMSP) e 5 no Hospital das Clínicas de Ribeirão Preto (HCFMRP).

Todas as pacientes apresentaram ambiguidade genital ao nascimento, que foram quantificadas pelo Prader score (I a V) (Prader 1954). Os dados do Prader score foram obtidos por análise retrospectiva da descrição da genitália nos prontuários. Uma paciente apresentou Prader I, 26 pacientes Prader II, 94 pacientes Prader III, 55 pacientes Prader IV e 11 pacientes Prader V.

As pacientes com a forma perdedora de sal, além do quadro de virilização, apresentaram história de crise de perda de sal, caracterizada por desidratação acompanhada de hiponatremia e hipercalemia nas primeiras semanas de vida.

Noventa e oito pacientes apresentaram a forma perdedora de sal e 75 a forma virilizante simples, em 14 não foi possível diferenciar a forma perdedora de sal da virilizante simples devido a instituição precoce da terapia de reposição hormonal. Todas as pacientes tiveram o diagnóstico de forma clássica confirmado através da dosagem da $170 \mathrm{H}$-progesterona sérica $\geq 20 \mathrm{ng} / \mathrm{mL}$ e/ou após diagnóstico molecular 
(Bachega et al 2004). Os dados clínicos, hormonais e moleculares das pacientes apresentam-se descritos na Tabela 1.

Para o diagnóstico molecular de forma clássica da hiperplasia adrenal congênita, em estudos anteriores, foram coletadas amostras de DNA genômico de sangue periférico das pacientes e de pelo menos um dos pais para o estudo de segregação das mutações. As técnicas utilizadas nestes trabalhos foram: Southern blott ou MLPA (Multiplex Ligation-dependent Probe Amplification) para a detecção de grandes rearranjos gênicos e PCR alelo-específico e/ou sequenciamento para a identificação das mutações de ponto (Bachega et al 1998 e 1999, Paulino et al 1999, Torres et al 2003).

De acordo com o comprometimento da atividade da 21-hidroxilase predita pelas mutações no gene CYP21A2, as pacientes foram divididas em dois grupos, $A$ e B, (Tusié-Luna et al 1990, Higashi et al 1991, Speiser et al 1992). No grupo genotípico $A(n=122)$, as pacientes carreavam, em ambos os alelos, mutações que predizem total ou quase total comprometimento da atividade enzimática $(\leq 2 \%)$. Este grupo inclui as seguintes mutações: deleções CYP21A2, grandes rearranjos gênicos, IVS2-13A/C>G (I2 splice), IVS2-2A>G, deleção 8 bp (p.G110Efs), p.Ser170fs (c.511_512insA), exon 6 cluster (p.1236N, p.V237E, p.M239K), p.Leu307fs (c.923_924insT), p.G291S, p.Q318X, p.R356W, p.R408C e p.G424S.

No grupo genotípico B $(n=58)$, as pacientes carreavam mutações que predizem atividade enzimática residual de 3-7\%, em homozigose ou em heterozigose composta com as do grupo A. As mutações do grupo B são p.I172N e p.R426H. Nas 7 pacientes remanescentes o genótipo $210 \mathrm{H}$ não foi disponível. 
Durante o desenvolvimento desta pesquisa, 12 mulheres com forma clássica, da casuística do Hospital das Clínicas de São Paulo, foram submetidas à genitoplastia corretiva. Amostras de pele genital foram coletadas para estudo de expressão gênica. Os dados clínicos e moleculares destas pacientes estão descritos na Tabela 2. 


\section{MÉTODOS}


Este trabalho foi integralmente desenvolvido no Laboratório de Hormônios e Genética Molecular LIM/42 da Faculdade de Medicina da Universidade de São Paulo.

\subsection{Dosagens Hormonais}

As concentrações séricas hormonais ao diagnóstico foram determinadas pelos seguintes métodos: $170 \mathrm{HP}$ por radioimunoensaio, testosterona por ensaio imunofluorimétrico e a androstenediona pelo ensaio quimioluminescente. Os coeficientes de variação intra- e inter-ensaio foram menores do que $15 \%$.

\subsection{Estudo Molecular}

O DNA genômico foi previamente extraído de leucócitos periféricos pela técnica salting-out ou fenol.

\subsection{Amplificação do DNA pela Reação em Cadeia da Polimerase}

Foram realizadas reações em cadeia da polimerase (PCR) para amplificar sequências de interesse do DNA genômico. Para cada reação de PCR utilizamos 100-200 ng de DNA genômico, $200 \mu \mathrm{M}$ de desoxinucleotídeos (dNTPs), 1,5 unidade da enzima GoTaq DNA Polimerase (Promega Corporation, USA), 25 pmoL de cada 
um dos pares de primer, 5x Green GoTaq Reaction buffer contendo 7,5 mM de Magnésio (Promega Corporation, USA) e água milique para completar um volume final de $50 \mu \mathrm{L}$.

O programa das PCRs seguiram o protocolo: temperatura alta inicial de 94$97^{\circ} \mathrm{C}$ por 5 minutos para desnaturar as fitas complementares, seguida por 35 ciclos de $96^{\circ} \mathrm{C}$ por 2 minutos, a temperatura de anneling variou de 51 a $62^{\circ} \mathrm{C}$ por 1 minuto, $72^{\circ} \mathrm{C}$ por 1 minuto e uma extensão final das fitas a $72^{\circ} \mathrm{C}$ por 30 minutos. $\mathrm{O}$ termociclador utilizado foi o Veriti 96-Well Thermal Cycler (Applied Biosystems, Foster City, CA, USA).

Os produtos da PCR foram analisados por eletroforese em gel de agarose $1 \%$ com TAE 1\% em cuba de eletroforese horizontal (Gibco BRL, Life Technologies Inc. Gaithersburg, MD, USA). A separação eletroforética foi realizada por 40 minutos a 85 Volts ( 60mA), utilizando a fonte Model 250 (Gibco BRL, Life Technologies Inc. Gaithersburg, MD, USA).

Cinco microlitros dos produtos da PCR e 0,5 $\mu \mathrm{g}$ do marcador de peso molecular ФX174/Hae III (Invitrogen, Life Technology, Gaithersburg, MD, USA), usado como referência, foram carregados no gel de agarose. As bandas foram coradas com brometo de etídeo $(0,5 \mathrm{mg} / \mathrm{mL})$ (Invitrogen, Life Technology, Gaithersburg, MD, USA), visualizadas em luz ultravioleta (UV) e fotodocumentadas em sistema de captura de imagem Ultra Cam Digital Imaging A650 (Ultra Lum, Inc. Claremont, CA, USA). 


\subsubsection{CYP3A7}

O protocolo de amplificação da região promotora proximal e do exon 1 foi adaptado de Burk et al (2002), do exon 1 do pseudogene (CYP3AP1) de RodriguezAntona et al (2005b) e das regiões que flanqueiam os exons de 2 a 12 de Du et al (2007). Para o exon 13, os primers foram confeccionados no programa Primer 3. Os pares de primers e as temperaturas de annealing utilizados para a amplificação de cada região exônica e o tamanho dos fragmentos amplificados estão descritos na Tabela 3.

\subsubsection{Receptor Pregnano X}

As regiões que flanqueiam os oito exons codificadores (menos o exon 1 que não é traduzido em proteína) do gene PXR foram amplificadas com primers específicos, cujas sequências foram retiradas de protocolos publicados na literatura (Hustert et al 2001). Os pares de primers e as temperaturas de annealing para a amplificação de cada região exônica estão descritas na Tabela 4.

\subsubsection{Receptor Androstano Constitutivo}

Os pares de primers, flanqueando os exons de 1 a 9, foram desenhados com o programa Primer3. Para cada reação de amplificação realizamos uma PCR com 
gradiente para se determinar a temperatura de annealing ideal, iniciando a partir da temperatura de melting. Os pares de primers e as temperaturas de annealing para cada reação estão descritas na Tabela 5.

\subsubsection{P450 Óxido-Redutase}

O exon 12 do gene POR (região que contém a variante A503V) foi amplificado pela PCR com primers específicos que flanqueiam os exons 12 e 13, conforme previamente publicado (Huang et al 2008). O par de primer e a temperatura de annealing para a amplificação da região estão descritas na Tabela 6.

\subsubsection{7-Hidroxiesteróide Desidrogenase Tipo 5}

A região promotora do gene HSD17B5 (região que contém a variante

-71G) foi amplificada pela PCR, com primers confeccionados no programa Primer 3.

O par de primer e a temperatura de annealing para a amplificação da região estão descritas na Tabela 6. 


\subsubsection{Enzima 5a-redutase Tipo 2}

O exon 1 do gene SRD5A2, que contém as variantes missense V89L e A49T, foi amplificado com adaptação de protocolo previamente descrito por Li et al (2003). As condições das PCR estão descritas na Tabela 6.

\subsubsection{Receptor Androgênico}

Para amplificar a região de repetições CAG do exon 1 do gene $R A$ foi utilizada adaptação do protocolo descrito por Lubahn et al (1988) (Tabela 6).

\subsection{Estudo por Sequenciamento de DNA}

Para o rastreamento de variantes nos genes CYP3A7, PXR, CAR, POR, HSD17B5 e SRD5A2 (para confirmar os resultados obtidos no PCR-RFLP) realizamos reações de sequenciamento a partir dos produtos de PCR. Os produtos de PCR foram purificados através de pré-tratamento enzimático com $2 \mu \mathrm{L}$ de ExoSAP-IT (USB Corporation, Cleveland, OH, USA), para cada 50 ng de massa de DNA, conforme instruções do fabricante. Em seguida o produto de PCR purificado foi submetido à reação de sequenciamento utilizando o Kit $A B I$ Prism BigDye Terminator Cycle Sequencing Ready (Applied Biosystems, Foster City, CA, USA) com 5 pmoL dos mesmos primers utilizados para as reações de PCR (Tabelas 3 - 6). 
Para o ensaio de sequenciamento foi utilizado o termociclador Veriti 96-Well Thermal Cycler (Applied Biosystems, Foster City, CA, USA) seguindo o protocolo com 25 ciclos de: $96^{\circ} \mathrm{C}$ por 10 segundos, $50^{\circ} \mathrm{C}$ por 5 segundos e $60^{\circ} \mathrm{C}$ por 4 minutos.

Os produtos foram submetidos à eletroforese capilar em sequenciador automático de DNA e os eletroferogramas foram analisados através do software ABI PRISM 3100 Genetic Analyzer (Applied Byosystems, Foster City, CA, USA). Os resultados obtidos foram comparados com as respectivas sequências selvagens obtidas do Gene Bank, Ensembl ID: CYP3A7 (ENSG00000160870), PXR (ENSG00000144852), CAR (ENSG00000143257), POR (ENSG00000127948), HSD17B5 (ENSG00000196139), SRD5A2 (ENSG00000049319).

\subsection{Estudo por PCR-RFLP}

As variantes V89L e A49T do gene SRD5A2 foram identificadas através de ensaios de PCR-RFLP (Restriction Fragment Length Polymorphism) conforme protocolo adaptado de Li et al (2003).

Os ensaios de digestão enzimática para a pesquisa do alelo V89L foram realizados com $10 \mu \mathrm{L}$ de produto de PCR, 1,5 unidade da enzima Rsal (GT//AC), 0,2 $\mu \mathrm{L}$ de BSA, 2,0 $\mu \mathrm{L}$ de tampão e água milique para completar um volume final de 20 $\mu \mathrm{L}$. A reação ficou em banho-maria à $37^{\circ} \mathrm{C}$ durante 4 horas. A enzima de restrição reconhece o alelo selvagem, ou seja, quando presente o alelo $\mathrm{V}$, o fragmento com 124 pb é dividido em fragmentos com 89 pb e 35 pb, visualizados em gel de agarose 
$3 \%$. Na presença de homozigose para o alelo $L$ observa-se apenas o fragmento com $124 \mathrm{pb}$ e na presença de heterozigose os fragmentos com 124, 89 e 35 pb (Figura $9)$.

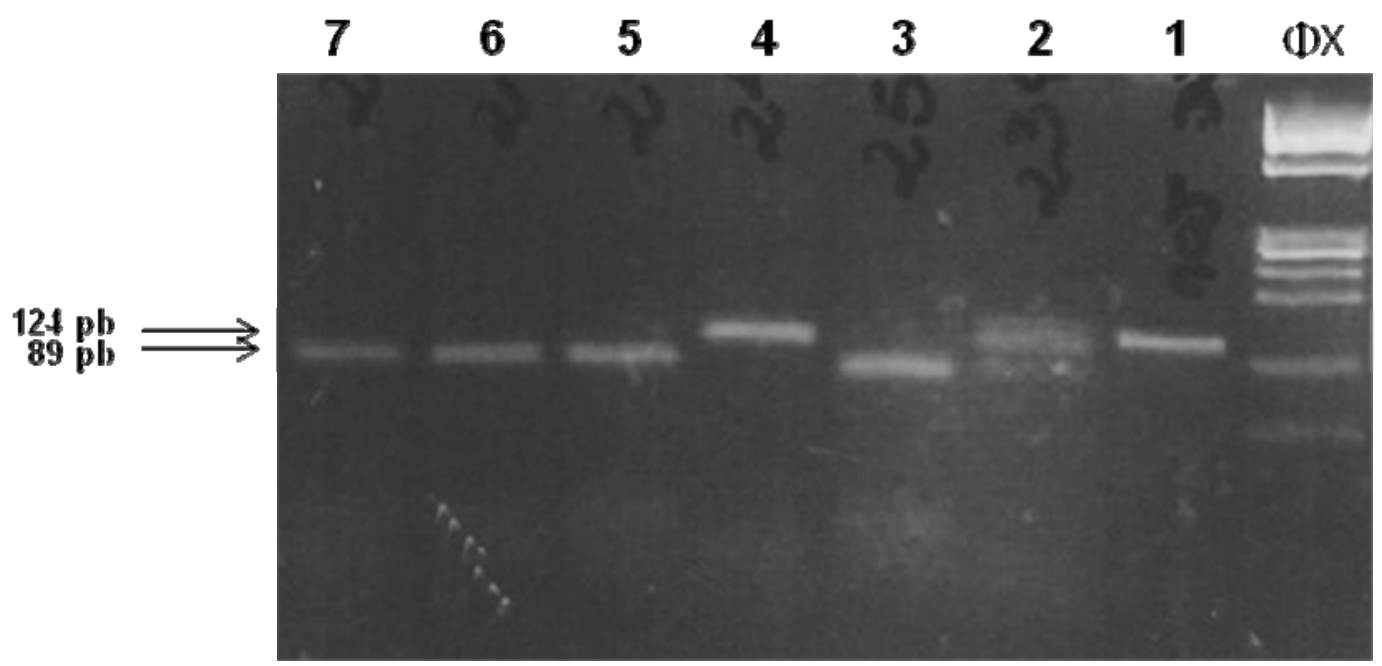

Figura 9. Eletroforese em gel de agarose $3 \%$, corado com brometo de etídeo, dos produtos de digestão enzimática (enzima Rsal) para rastreamento do alelo V89L SRD5A2. 1: amostra de produto de PCR não digerido (124 pb), 2: heterozigoto, observa-se as bandas com 124 e 89 pb, a banda de 35 pb não é visualizada, 3: homozigoto selvagem, observa-se uma única banda com 89 pb, 4: homozigoto variante, observa-se uma única banda com $124 \mathrm{pb}, 5-7$ : homozigoto selvagem. O marcador de peso molecular $\Phi \times 174 /$ Hae III foi usado como referência.

O alelo A49T foi pesquisado pela digestão de $10 \mu \mathrm{L}$ de produto de PCR com 1,5U da enzima Mwol (GCNNNNN//NNGC), 0,2 $\mu \mathrm{L}$ de BSA, 2,0 $\mu \mathrm{L}$ de tampão e água milique para completar volume final de $20 \mu \mathrm{L}$. A reação ficou em banho-maria a $60^{\circ} \mathrm{C}$ durante 6 horas. A enzima reconhece o alelo selvagem, ou seja, quando o alelo A está presente, o fragmento de 122 pb é dividido em fragmentos com 89 pb e $33 \mathrm{pb}$, visto em gel de agarose $3 \%$. Para monitorar o tamanho dos fragmentos gerados pela digestão enzimática foi usado o marcador de peso molecular ФX174/HaeIII (Invitrogen, Life Technology, Gaithersburg, MD, USA). Na presença de 
homozigose para o alelo $\mathrm{T}$ apenas se observa o fragmento com $122 \mathrm{pb}$ e na presença de heterozigose os fragmentos com 122, 89 e 33 pb.

Os resultados obtidos pelo método de PCR-RFLP, de pacientes que carrearam as variantes em heterozigose ou em homozigose, foram confirmados por sequenciamento direto a partir do produto da PCR.

\subsection{Análise de Fragmentos pelo Método GeneScan}

Para o estudo do número de repetições CAG do gene do receptor androgênico, $2 \mu \mathrm{L}$ de produto da PCR foram misturados a $24 \mu \mathrm{L}$ de formamida HIDI

e $1 \mu \mathrm{L}$ do padrão de peso molecular ROX-500 (Applied Biosystems, Foster City, CA, USA). Após desnaturação por 4 minutos a $94^{\circ} \mathrm{C}$ e repouso no gelo por 3 minutos, o material foi submetido à eletroforese capilar no sequenciador automático ABI PRISM Genetic Analyser 310 Automatic DNA Sequencer (Applied Biosystems) e analisado pelo software GeneScan (Applied Biosystems). O número de repetições CAG contido em cada fragmento amplificado foi determinado pela equação da reta resultante da análise de regressão de Spearman, padronizada em estudo anterior (Rocha et al 2008). 


\subsection{Estudo Funcional da Expressão Gênica Diferencial em Pele Genital}

\subsubsection{Coleta de Pele Genital}

A coleta dos fragmentos de pele genital para o estudo de expressão gênica foi realizada durante a cirurgia de genitoplastia. Estes fragmentos de pele genital, os quais normalmente são desprezados durante a genitoplastia, foram armazenados em microtubos estéreis e mantidos até o momento da extração do RNA a $\quad-80^{\circ} \mathrm{C}$ em nitrogênio líquido.

\subsubsection{Extração de RNA}

A extração do RNA total foi realizada pelo método do tiocianato de guanidinafenol-clorofórmio $\left(\operatorname{Trizol}^{\circledR}\right)$. Foram pesados $100 \mathrm{mg}$ do tecido (pele genital) e homozenizados com $1 \mathrm{~mL}$ de Trizol $^{\circledR}$ (Invitrogen Life Technologies).

- $\quad$ Separação de fases

Foram adicionados $200 \mu \mathrm{L}$ de clorofórmio à solução, agitados vigorosamente, mantidos em repouso por 10 min a temperatura ambiente e centrifugados a 12.000 rpm por $15 \min$ a $4^{\circ} \mathrm{C}$ para formação de 3 fases da solução, as quais são: um sobrenadante translúcido, uma fase intermediária leitosa e uma fase inferior rosada, 
contendo respectivamente RNA, DNA e proteínas. Após, o sobrenadante translúcido foi transferido para um novo microtubo.

- $\quad$ Precipitação do RNA

Nesta última solução, foram adicionados $500 \mu \mathrm{L}$ de isopropanol, homogeneizados levemente, mantidos em repouso por $10 \mathrm{~min}$ a temperatura ambiente e centrifugados a $12.000 \mathrm{rpm}$ por $10 \mathrm{~min}$ a $4^{\circ} \mathrm{C}$. Após, o sobrenadante foi desprezado.

- $\quad$ Lavagem do RNA

Foram adicionados $1 \mathrm{~mL}$ de etanol 75\% (diluído em água RNAse free) gelado a $-20^{\circ} \mathrm{C}$, homogeneizados com a pipeta e centrifugados a $12.000 \mathrm{rpm}$ por $5 \mathrm{~min}$ a $4^{\circ} \mathrm{C}$ para a formação do pellet.

- $\quad$ Secagem e eluição do RNA

O pellet foi mantido à temperatura ambiente para evaporar todo o etanol. Após, a amostra de RNA foi eluída em $50 \mu \mathrm{L}$ de água RNAse free. O RNA foi conservado em um refrigerador a $-80^{\circ} \mathrm{C}$.

\subsubsection{Avaliação da Qualidade/Quantificação do RNA e Síntese do cDNA}

A integridade de cada amostra de RNA extraída foi testada pela avaliação das bandas $28 \mathrm{~S}$ e $18 \mathrm{~S}$ de RNA ribossômico após eletroforese em gel de garose a 1\% com $1 \mu \mathrm{L}$ de RNA total (Figura 10). 


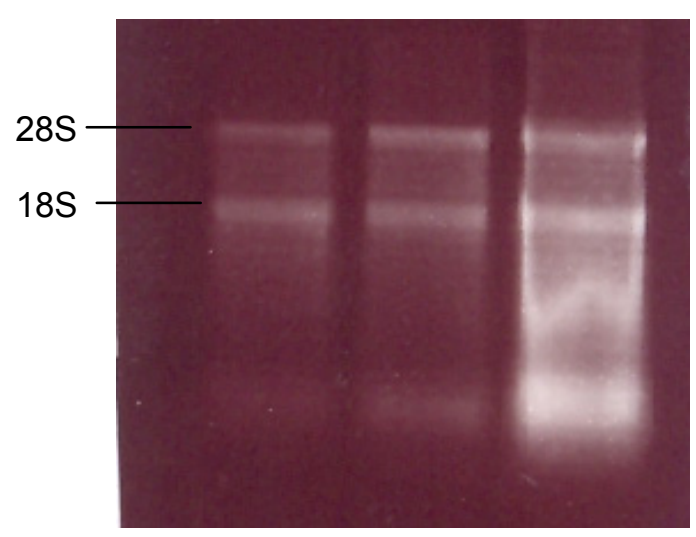

Figura 10. Gel de agarose 1\% mostrando a integridade da extração de RNA em amostras de pele genital de 3 pacientes. Visualização das bandas de RNA ribossômico 18 e $28 \mathrm{~S}$.

A concentração de RNA total das amostras foi medida por leitura em espectrofotômetro UV (BioPhotometer; Eppendorf AG, Hamburg), com absorbância de 230, 260 e $280 \mathrm{~nm}$ a fim de se avaliar o grau de pureza.

O DNA complementar (cDNA) foi sintetizado por transcrição reversa a partir de 200 ng de RNA total de cada amostra para um volume final de $50 \mu \mathrm{L}$, utilizando o kit Hight Capacity cDNA Reverse Transcription (Applied Biosystems, Foster City CA, USA), seguindo as instruções do fabricante. $\mathrm{O}$ ciclo no termociclador foi de $25^{\circ} \mathrm{C}$ por 10 min seguido de $37^{\circ} \mathrm{C}$ por 2 horas. 


\subsubsection{Quantificação da Expressão Gênica Diferencial pelo Sistema Taqman}

O estudo de expressão gênica dos genes alvos HSD17B5, SRD5A1, SRD5A2 e $R A$ e dos genes endógenos foi realizado através da PCR em tempo real pelo sistema Taqman (Applied Biosystems).

As reações foram preparadas em triplicata, em um volume final de $25 \mu \mathrm{L}$ contendo 12,5 $\mu \mathrm{L}$ de Taqman Universal PCR Master Mix, 1,25 $\mu$ de cada ensaio com primers (Applied Biosystems), $3 \mu \mathrm{L}$ de cDNA (obtido a partir de 200 ng de RNA total) e $8,25 \mu \mathrm{L}$ de água mili-Q. Foram repetidas as reações cujos resultados apresentaram um coeficiente de variação maior do que $2 \%$ entre as triplicatas. As reações consistiram em uma incubação a $50^{\circ} \mathrm{C}$ por $2 \mathrm{~min}$, a $95^{\circ} \mathrm{C}$ por 10 min e 40 ciclos de: desnaturação de $95^{\circ} \mathrm{C}$ por $15 \mathrm{seg}$, anelamento e extensão a $60^{\circ} \mathrm{C}$ por 1 min, no termociclador ABI 7000 Sequence Detection System (Applied Biosystems).

\subsubsection{Seleção dos Genes Endógenos}

Para determinar quais genes são mais apropriados para o estudo de expressão nas amostras de pele genital, foi calculada a estabilidade de expressão de 12 genes endógenos: CYC, GUS, GAPDH, ACTB, B2M, HPRT, YM, TBP, TfR, PGK1, UBC e HMBS (Tabela 7), utilizando o programa geNorm (http://medgen.ugent.be/genorm/).

Para cada gene endógeno o programa determinou a variação pareada $(V)$ em relação a todos os outros genes avaliados, como o desvio padrão das razões de 
expressão transformadas logaritimicamente, e definiu a medida de estabilidade do gene endógeno $(M)$ como a média da variação pareada de um gene particular em relação aos demais genes. Genes com menor valor de $M$ tem a expressão mais estável (Vandesompele et al 2002).

Recomenda-se o uso dos 3 genes endógenos mais estáveis, e os genes que apresentaram o menor valor de $M$ (maior estabilidade) nas amostras de pele genital foram: CYC, PGK1 e B2M. A média geométrica dos genes endógenos escolhidos é então utilizada para a normalização da expressão dos genes alvos.

\subsubsection{Quantificação Relativa dos Genes Alvos}

O método de quantificação utilizado foi a quantificação relativa (comparação da expressão em número de vezes), que mede a quantidade do produto alvo em relação a uma amostra de referência. O cálculo foi feito pela fórmula aritmética ${ }^{-}$ $\Delta \Delta \mathrm{CT}[(\mathrm{Ct}$ alvo - Ct endógeno da amostra) - (Ct alvo - Ct endógeno do calibrador)]. Um pool de pele genital de meninos normais circuncidados foi usado como calibrador. O limiar utilizado para determinar um aumento ou diminuição de expressão foi uma diferença de duas vezes para mais ou para menos em relação aos valores normais. 


\subsubsection{Padronização das Curvas de Eficiência}

Foram feitas diluições progressivas das amostras de cDNA com a intenção de demonstrar uma diferença entre as diluições de um ciclo (CT). A curva padrão foi realizada em poços separados (singleplex). Os pontos da reta foram estabelecidos pela relação do log da quantidade de RNA total da amostra no eixo das abscissas e o CT da amostra no eixo das ordenadas. O experimento foi validado para os genes alvos: HSD17B5, SRD5A1, SRD5A2, RA e endógenos: CYC, PGK1 e B2M uma vez que o valor da inclinação da reta foi próximo de -3,3 e uma relação de equação da reta $r \geq 0,99$. Posteriormente a curva de eficiência em cada ponto da reta foi estabelecida pela relação do log da quantidade de RNA total da amostra no eixo das abscissas e o $\Delta \mathrm{CT}$ da amostra em cada ponto de diluição. As curvas foram adequadas uma vez que a inclinação da reta ficou entre $-0,1$ a 0,1; demonstrando que os genes alvos e endógenos têm uma eficiência equivalente de amplificação e validando a utilização do método do Ct comparativo $\left(2^{-\Delta \Delta C T}\right)$ para a análise dos dados. 


\subsection{Análise Estatística}

As análises paramétricas foram calculadas por $t$-test e escritas como média \pm desvio padrão (SD). As análises que falharam no teste de normalidade $(P<0,05)$ foram calculadas pelo teste não paramétrico Mann-Whitney rank sum e demonstradas por mediana e intervalo interquartil (25 - 75), quando a comparação foi feita entre dois grupos. As análises comparando mais de 2 grupos foram feitas utilizando o teste Kruskal-Wallis One Way.

As variantes em Equilíbrio de Hardy-Weinberg e com frequência alélica maior do que $2 \%$ foram selecionadas para as análises de correlação com o Prader score. As variantes foram classificadas baseadas no modelo genético de Dominância.

Regressão linear uni- e múltipla foram realizadas para testar a influência do genótipo da $210 \mathrm{H}$ e de cada variante (variáveis independentes) no grau de virilização genital, usando o Prader score de I a V, como variável dependente. Adicionalmente, a mesma análise foi executada em cada genótipo da $210 \mathrm{H}$, grupo $\mathrm{A}$ e B, separadamente.

A comparação das frequências dos alelos curto e longo do receptor androgênico entre os grupos de Prader scores foram realizadas pelo teste exato de Fisher.

A significância estatística foi considerada quando $P<0,05$.

Todas as análises foram efetuadas usando o software SigmaStat versão 3.5 para Windows (Systat Software Inc., Chicago, IL USA) e os gráficos realizados no MINITAB versão 14 para Windows (Minitab Inc., State College, Pennsylvania, USA). 
6. RESULTADOS 


\subsection{Frequência das Mutações no Gene CYP21A2}

As mutações de ponto mais frequentes encontradas no gene da 21hidroxilase foram IVS2 -13A/C>G (I2 splice) em $37,6 \%$ dos alelos e p.I172N em $17,8 \%$ dos alelos. Outras mutações que resultam em comprometimento total da atividade enzimática foram identificadas em $28,9 \%$ dos alelos, tais como: p.Q318X, deleção 8pb (p.G110Efs), exon 6 cluster (p.I236N, p.V237E, p.M239K), p.Leu307fs (c.923_924insT), p.G291S, p.R356W, p.R408C, p.G424S e p.Arg483fs. Grandes rearranjos gênicos (LR), como deleções do gene CYP21A2 e grandes conversões, foram identificados em $11 \%$ dos alelos e novas mutações de ponto em $2,4 \%$ dos alelos (Tabela 8 ). Apenas $29 \%$ das pacientes eram homozigotas para uma mutação, as demais eram heterozigotas compostas.

\subsection{Correlação entre os Genótipos 210H e as Formas Clínicas}

Sessenta e cinco porcento das pacientes pertencem ao grupo genotípico $210 H$ A, 31\% ao grupo B e em 4\% não foi possível obter o genótipo devido a falta de dados. As 7 pacientes que carreavam mutações novas estão descritas na Tabela 9.

Dentre as pacientes do grupo A, 76,2\% apresentaram a forma perdedora de sal, $15,6 \%$ a forma virilizante simples e em $8,2 \%$ a diferenciação das duas formas clínicas não foi possível devido a instituição precoce da terapia. No grupo B, $5 \%$ das pacientes apresentaram a forma perdedora de sal e $95 \%$ a forma virilizante simples. Os grupos A e B do genótipo $210 \mathrm{H}$ apresentaram associação significativa com as formas perdedora de sal e virilizante simples, respectivamente $(P<0,001)$. 


\subsection{Correlação entre os Genótipos $210 H$ e as Concentrações Basais Hormonais}

As concentrações basais séricas de 170HP dos grupos genotípicos A e B foram $160(89-264) \mathrm{ng} / \mathrm{mL}$ e $107(77-205) \mathrm{ng} / \mathrm{mL}$, respectivamente $(P=0,174)$ (Figura 11).

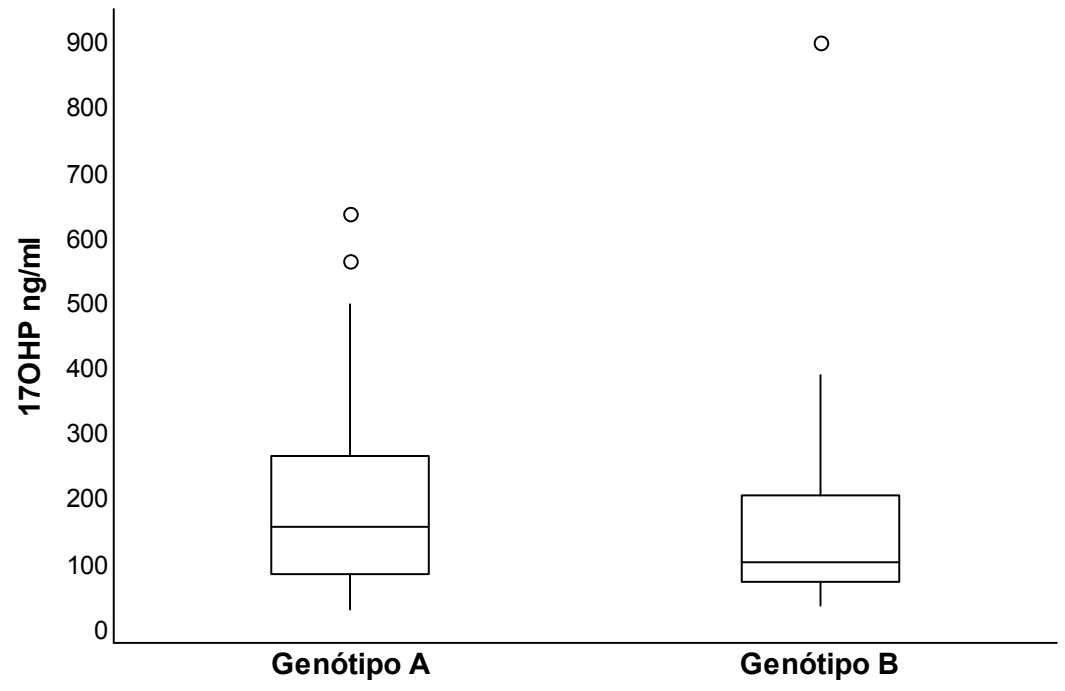

Figura 11. Boxplot das concentrações basais de 17OHP das pacientes com hiperplasia adrenal congênita de acordo com o genótipo $210 \mathrm{H}$, grupos $\mathrm{A}$ e $\mathrm{B}(P=0,174)$.

As concentrações basais de androstenediona das pacientes com os genótipos A e B foram 11,8 (6 - 25) ng/mL e 7,0 (4 - 9) ng/mL, respectivamente $(P=$ 0,003) (Figura 12); e de testosterona foram $173(114-418) \mathrm{ng} / \mathrm{dL}$ e 92 (59-226) $\mathrm{ng} / \mathrm{dL}$, respectivamente $(P=0,013)$ (Figura 13). 


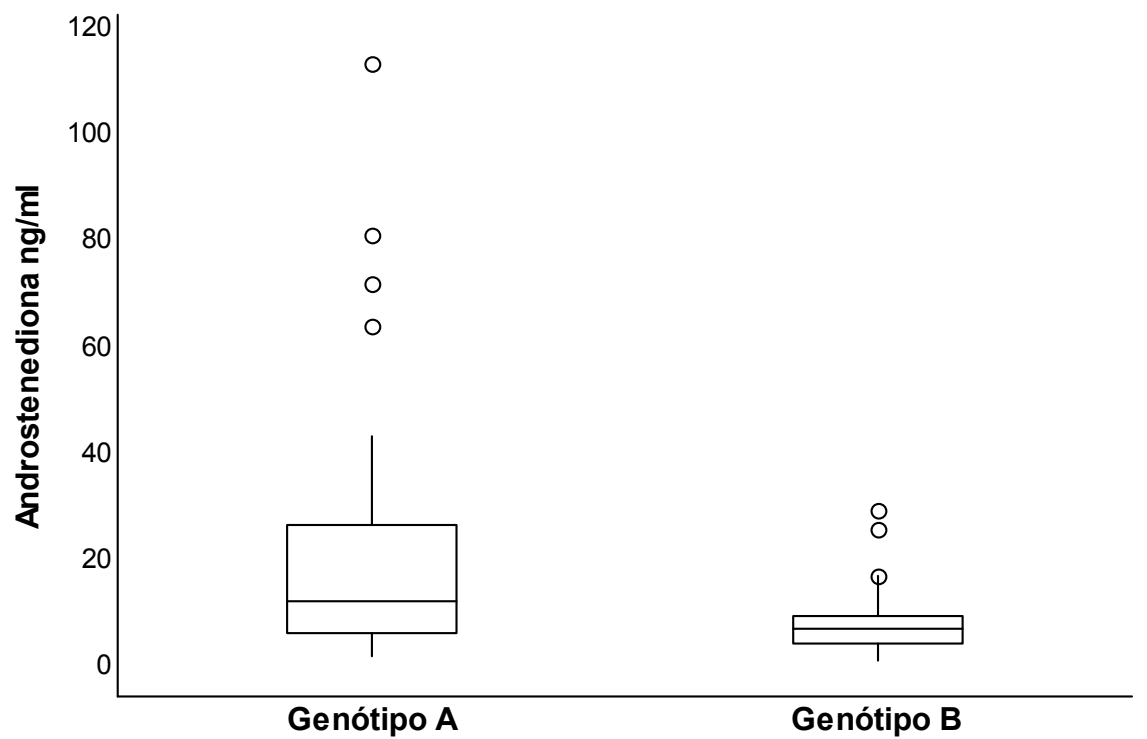

Figura 12. Boxplot das concentrações basais de androstenediona de pacientes com hiperplasia adrenal congênita de acordo com o genótipo $210 \mathrm{H}$, grupos A e B $(P=0,003)$.

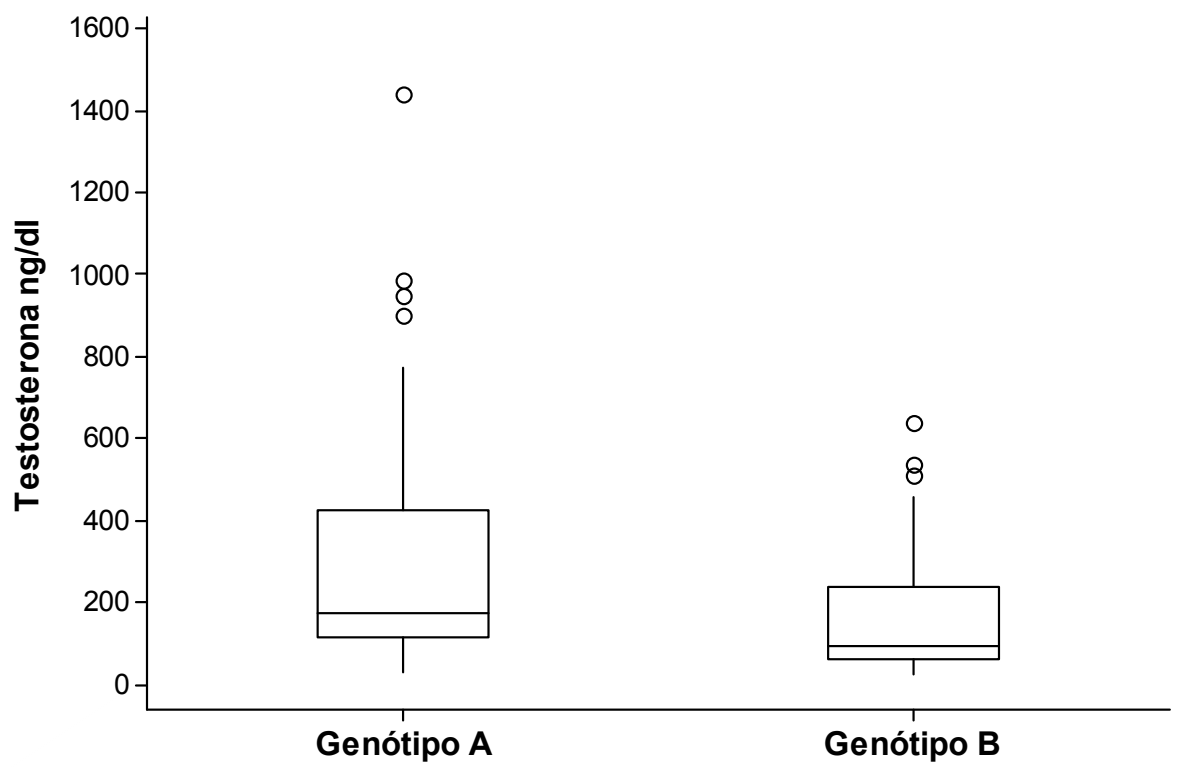

Figura 13. Boxplot das concentrações basais de testosterona das pacientes com hiperplasia adrenal congênita de acordo com o genótipo $210 \mathrm{H}$, grupos A e B $(P=0,013)$. 


\subsection{Correlação do Prader score com os Genótipos 210H e com as Concentrações Basais Hormonais}

As mutações mais frequentes do gene CYP21A2 e a distribuição com o Prader score estão demonstradas na Tabela 8.

As pacientes pertencentes ao grupo $\mathrm{A}$ apresentaram intensidade maior de virilização da genitália externa do que as pacientes com o genótipo B, III (III - IV) e III (II - III), respectivamente $(P<0,001)$. Entretanto, apesar desta significância, o grau de virilização da genitália externa apresentou uma grande sobreposição entre os dois grupos, variando de Prader score II a V no grupo A e de I a V no grupo B (Figura 14).

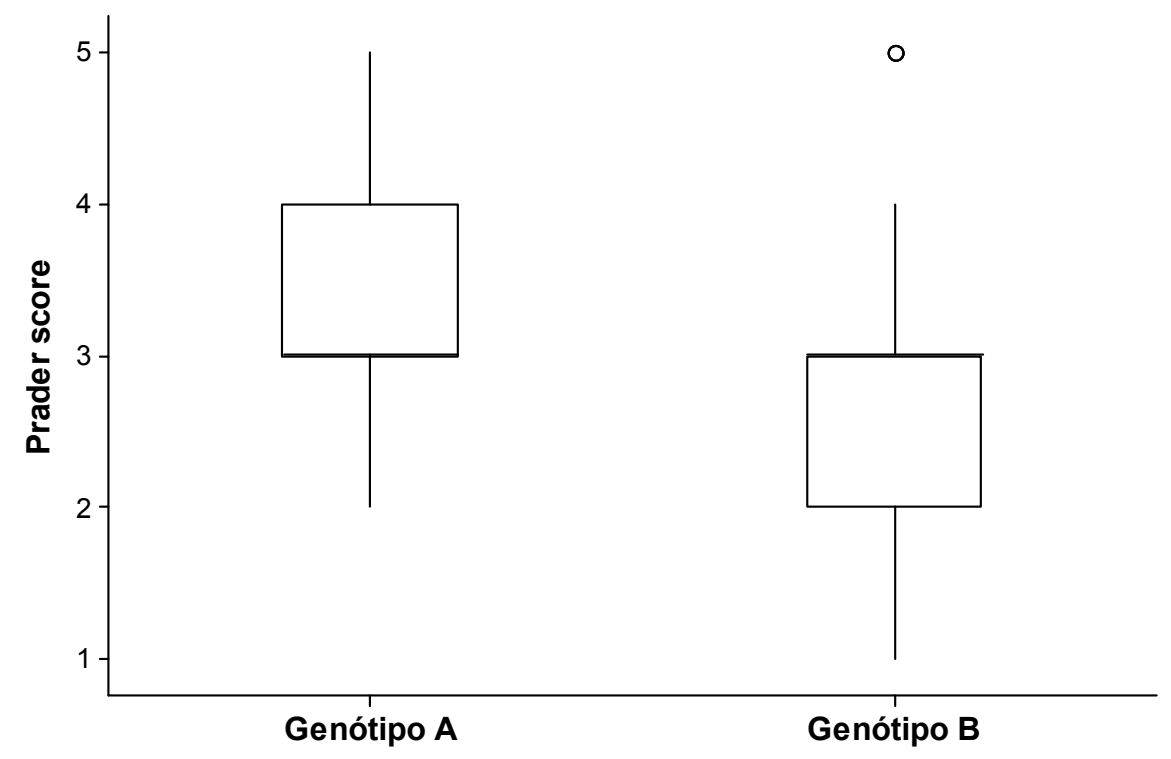

Figura 14. Boxplot do grau de virilização da genitália externa (Prader score I a V) das pacientes com hiperplasia adrenal congênita de acordo com o genótipo $210 \mathrm{H}$, grupos $A$ e $B(P<0,001)$. 
O Prader score também foi avaliado, em uma segunda análise, de acordo com a gravidade do genótipo do grupo A: as pacientes foram subdivididas em genótipos A1/A1 versus A1/A2 e A2/A2, uma vez que o primeiro grupo prediz total comprometimento da atividade enzimática enquanto que o segundo atividade residual de $2 \%$. Não foram identificadas diferenças na intensidade de virilização genital entre os grupos $A 1$ e $A 2(P=0,862)$. Por isso, nas análises subsequentes, todas as pacientes carreando os diferentes genótipos do grupo A foram avaliadas em um único grupo.

Em outra análise, as pacientes foram agrupadas de acordo com o grau de virilização genital e foram comparadas as concentrações séricas basais de testosterona e, interessantemente, diferenças significantes não foram encontradas: Prader I + II, 139 (102 - 344) ng/dL; Prader III, 204 (70 - 418) ng/dL; Prader IV, 125 $(87$ - 380) ng/dL e Prader V 129 (108 - 135) ng/dL ( $P=0,914)$ (Figure 15). 


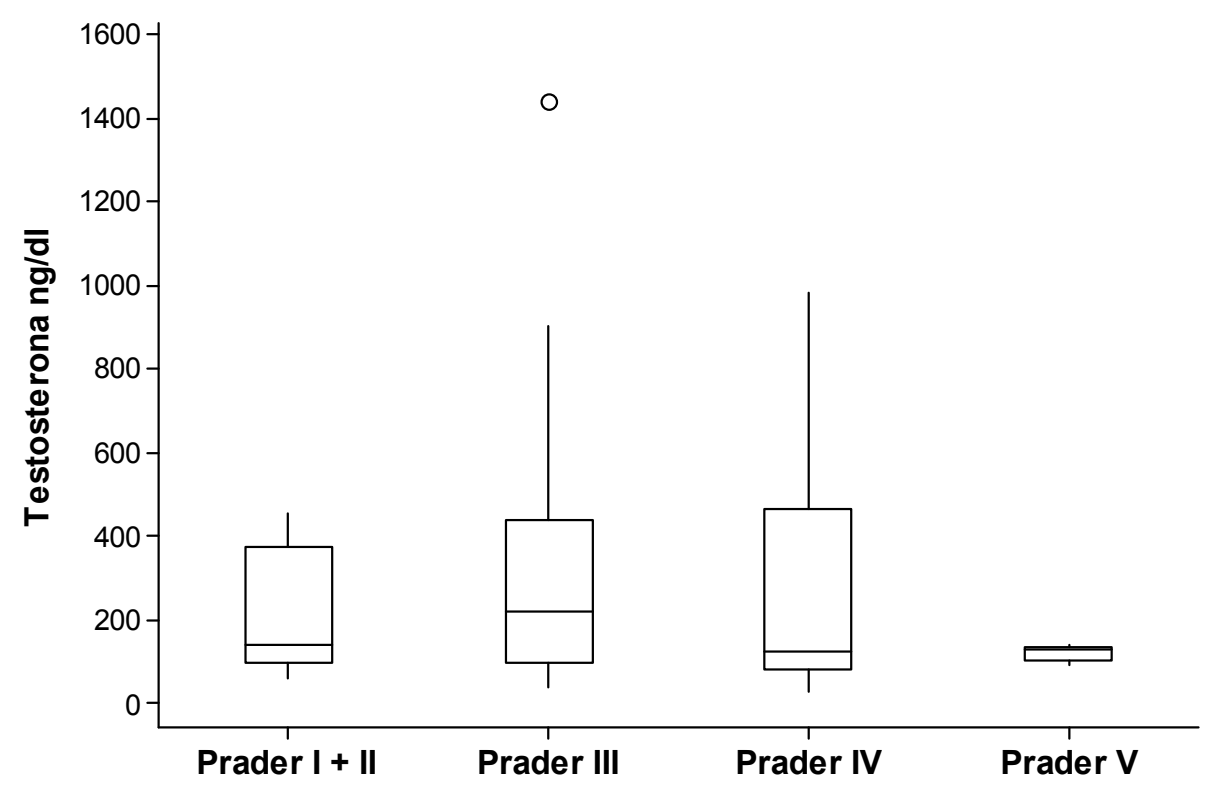

Figura 15. Boxplot das concentrações basais de testosterona de acordo com o grau de virilização da genitália externa (Prader score I a V) nas pacientes com hiperplasia adrenal congênita $(P=0,914)$.

\subsection{CYP3A7}

No sequenciamento da região promotora proximal do gene CYP3A7 em 187 pacientes, foi identificada uma paciente carreando o alelo $C Y P 3 A 7^{*} 1 \mathrm{~B}, 9$ pacientes o alelo $C Y P 3 A 7^{*} 1 \mathrm{C}, 1$ paciente o alelo $C Y P 3 A 7^{*} 1 \mathrm{D}$ e 4 pacientes o alelo $C Y P 3 A 7^{*} 1 \mathrm{E}$; todas as variantes estavam em heterozigose.

O exon 11 foi sequenciado em 160 pacientes, a variante polimórfica (T409R), alelo CYP3A7*2 (rs2257401), foi encontrada em 59 pacientes em heterozigose e em 9 pacientes em homozigose, com frequência alélica de $24 \%$.

O alelo $C Y P 3 A 7^{\star} 2$ esteve em desequilíbrio de ligação com a variante CYP3A7_39256T $\rightarrow A$, localizada no íntron 1 do pseudogene CYP3AP1, em 97\% dos casos. 
As outras regiões que flanqueiam os exons 1 - 10 e 12 - 13 foram sequenciadas em 136 pacientes. Nas regiões exônicas foram encontradas 4 variantes: 2 silenciosas (rs45466796, rs113539362) e 2 missense (rs144169200, rs115246825). Nas regiões intrônicas que flanqueiam os exons foram encontradas 4 variantes (rs45515892, rs45446903, rs41279866, rs45600842) e outras duas novas substituições, as quais não alteram os sítios conservados de splicing quando analisadas em sites de predição. Todas as variantes encontradas no gene CYP3A7 e suas respectivas frequências alélicas nesta casuística e na população caucasiana estão descritas na Tabela 10.

Tabela 10. Frequência das variantes encontradas no gene CYP3A7 das pacientes com hiperplasia adrenal congênita e na população caucasiana.

\begin{tabular}{|c|c|c|c|c|c|}
\hline \multirow{2}{*}{ SNP } & \multirow{2}{*}{ Localização } & \multirow{2}{*}{$\begin{array}{c}\text { Alelo ou } \\
\text { troca }\end{array}$} & \multirow{2}{*}{ NCBI } & HAC & Caucasiano \\
\hline & & & & $\%$ & $\%$ \\
\hline 1 & promotor & CYP3A7*1B & rs3823647 & 0,5 & 11 \\
\hline 2 & promotor & CYP $3 A 7^{*} 1 C$ & rs11568825 & 2,5 & ${ }^{1} 3$ \\
\hline 3 & promotor & $C Y P 3 A 7 * 1 D$ & rs55798860 & 0,5 & 11 \\
\hline 4 & promotor & CYP3A7*1E & rs28451617 & 1 & ${ }^{2} 14$ \\
\hline 5 & exon 4 & P87P & rs45466796 & 1 & ${ }^{2} 5$ \\
\hline 6 & exon 7 & F203L & rs144169200 & 0,5 & ${ }^{2} 0,1$ \\
\hline 7 & exon 8 & I246V & rs115246825 & 0,5 & 21 \\
\hline 8 & exon 11 & CYP $3 A 7^{*} 2$ & rs2257401 & 24 & 38 \\
\hline 9 & exon 13 & T499T & rs113539362 & 0,5 & ${ }^{2} 0,5$ \\
\hline 10 & íntron 2 & $-159 T>C$ & rs45515892 & 3 & ${ }^{2} 13$ \\
\hline 11 & íntron 4 & $-52 \mathrm{~T}>\mathrm{A}$ & rs45446903 & 4 & ${ }^{2} 3$ \\
\hline 12 & íntron 4 & $-14 G>A$ & rs41279866 & 7 & ${ }^{2} 5$ \\
\hline 13 & íntron 6 & $+73 \mathrm{~T}>\mathrm{C}$ & rs45600842 & 7 & ${ }^{2} 26$ \\
\hline 14 & íntron 6 & $+77 G>A$ & ND & 0,5 & ND \\
\hline 15 & íntron 11 & $-59 \mathrm{~T}>\mathrm{C}$ & ND & 0,5 & ND \\
\hline
\end{tabular}

Burk et al 2002', HapMap (Ensembl) ${ }^{2}$, Rodriguez-Antona et al 2005a ${ }^{3}$, ND: dado não disponível. A contagem dos nucleotídeos se da a partir do primeiro $G$ do $A G$ inicial de cada exon quando (-) e a partir do primeiro G do GT final de cada exon quando (+). Gene: ENSG00000160870, Transcrito: ENST00000336374. 


\subsection{Receptor Pregnano X}

O sequenciamento das regiões exônicas do gene PXR (NR1/2) em 91 pacientes identificou 7 variantes: sendo 4 delas silenciosas (rs12721611, rs61755051, rs12721600, rs12721612) e 3 missense (rs12721613, rs12721607, rs35761343). Nas regiões intrônicas que flanqueiam os exons, foram encontradas 3 variantes (rs12721616, rs2276707, rs3732358). As frequências alélicas das variantes encontradas no gene $P X R$ nesta casuística e na população caucasiana, bem como os seus efeitos na transativação da família CYP3A estão descritos na Tabela 11.

Tabela 11. Frequência das variantes do gene $P X R$ em 91 pacientes com hiperplasia adrenal congênita e na população caucasiana.

\begin{tabular}{|c|c|c|c|c|c|c|}
\hline \multirow{2}{*}{ SNP } & \multirow{2}{*}{ Localização } & \multirow{2}{*}{ Troca } & \multirow{2}{*}{ NCBI } & HAC & Caucasiano & \multirow{2}{*}{$\begin{array}{c}\text { Atividade no } \\
\text { CYP3A }\end{array}$} \\
\hline & & & & $\%$ & $\%$ & \\
\hline 16 & exon 2 & P27S & $r s 12721613$ & 1 & ${ }^{1} 0$ & $=$ \\
\hline 17 & exon 2 & G36R & rs 12721607 & 2 & ${ }^{1} 3$ & $=$ \\
\hline 18 & exon 4 & T164T & rs12721611 & 2 & ${ }^{2} 6$ & ND \\
\hline 19 & exon 5 & G232G & rs61755051 & 1 & 21 & ND \\
\hline 20 & exon 5 & G181G & rs12721600 & 1 & ${ }^{2} 0,5$ & ND \\
\hline 21 & exon 6 & G278G & rs 12721612 & 0,5 & ${ }^{2} 6$ & ND \\
\hline 22 & exon 8 & A370T & rs35761343 & 0,5 & ${ }^{1} 0$ & $\uparrow$ \\
\hline 23 & íntron 2 & $-29 C>T$ & rs12721616 & 2 & ${ }^{2} 4$ & ND \\
\hline 24 & íntron 6 & $-17 C>T$ & rs2276707 & 20 & ${ }^{3} 15$ & $\uparrow$ \\
\hline 25 & 3'UTR & $* 15 \mathrm{G}>\mathrm{A}$ & rs3732358 & 2 & 210 & ND \\
\hline
\end{tabular}

Hustert et al 2001', HapMap (Ensembl) ${ }^{2}$, Zhang et al 2008 ${ }^{3}$. (=): a variante não muda a transativação do CYP3A, $(\uparrow)$ : a variante aumenta a transativação do $C Y P 3 A$, ND: dado não disponível. A contagem dos nucleotídeos se da a partir do primeiro $G$ do $A G$ inicial de cada exon quando (-) e a partir do primeiro $G$ do GT final de cada exon quando (+). Gene: ENSG00000144852, Transcrito: ENST00000393716. 


\subsection{Receptor Androstano Constitutivo}

O sequenciamento das regiões exônicas do gene CAR (NR1/3) em 91 pacientes identificou a variante silenciosa rs2307424. Nas regiões intrônicas foram encontradas 8 variantes (rs2307426, rs35709078, rs2502815, rs2307420, rs2307418, rs35796551, rs141260451) e uma nova, a qual não alterou o reconhecimento do sítio conservado de splicing quando analisada em sites de predição. As frequências das variantes encontradas no gene $C A R$ nesta casuística e na população caucasiana estão descritas na Tabela 12.

Tabela 12. Frequência das variantes do gene CAR em 91 pacientes com hiperplasia adrenal congênita e na população caucasiana.

\begin{tabular}{|c|c|c|c|c|c|}
\hline \multirow{2}{*}{ SNP } & \multirow{2}{*}{ Localização } & \multirow{2}{*}{ Troca } & \multirow{2}{*}{ NCBI } & HAC & Caucasiano \\
\hline & & & & $\%$ & $\%$ \\
\hline 26 & exon 4 & P180P & $r s 2307424$ & 31 & 129 \\
\hline 27 & íntron 1 & $+19 A>G$ & rs2307426 & 0,5 & ${ }^{1} 1$ \\
\hline 28 & íntron 1 & $-89 \mathrm{C}>\mathrm{T}$ & rs35709078 & 0,5 & ${ }^{1} 2$ \\
\hline 29 & íntron 2 & $-99 C>T$ & rs2502815 & 31 & ${ }^{1} 23$ \\
\hline 30 & íntron 2 & $+29 C>G$ & rs141260451 & 0,5 & ND \\
\hline 31 & íntron 4 & $+41 A>G$ & rs2307420 & 2 & ${ }^{1} 0$ \\
\hline 32 & Íntron 6 & $-63 \mathrm{C}>\mathrm{T}$ & ND & 0,5 & ND \\
\hline 33 & íntron 7 & $+17 A>C$ & rs2307418 & 13 & ${ }^{1} 13$ \\
\hline 34 & upstream & $G>T$ & rs35796551 & 1 & ${ }^{1} 0,5$ \\
\hline
\end{tabular}

HapMap (Ensembl) ${ }^{1}$, ND: dado não disponível. A contagem dos nucleotídeos se da a partir do primeiro $G$ do $A G$ inicial de cada exon quando (-) e a partir do primeiro G do GT final de cada exon quando (+). Gene: ENSG00000143257, Transcrito: ENST00000367979. 


\subsection{Correlação das Variantes dos Genes CYP3A7, PXR e CAR com o Grau de Virilização Genital das Pacientes com HAC 210H}

A distribuição das variantes nos genes CYP3A7, PXR e CAR, que tiveram frequência maior do que $2 \%$, de acordo com os grupos genotípicos $210 \mathrm{H}$, forma clínica e Prader score está descrita na Tabela 13.

Tabela 13. Variantes dos genes CYP3A7, PXR e CAR, com frequência alélica maior do que $2 \%$, distribuídas de acordo com os grupos genotípicos $210 \mathrm{H}$ (A e B), forma clínica e com o grau de virilização genital.

\begin{tabular}{|c|c|c|c|}
\hline SNP & $\begin{array}{c}\text { Genótipo } \\
210 H\end{array}$ & $\begin{array}{l}\text { Forma } \\
\text { clínica }\end{array}$ & $\begin{array}{c}\text { Prader } \\
\text { score }\end{array}$ \\
\hline \multirow[t]{2}{*}{2} & $6 \mathrm{~A}$ & 6PS & II-V \\
\hline & $3 B$ & $3 \mathrm{VS}$ & $\|\mid-I\|$ \\
\hline \multirow[t]{2}{*}{8} & 48A,1ND & 34PS,10VS,5CL & II-V \\
\hline & 16B & $16 \mathrm{VS}$ & II-V \\
\hline \multirow[t]{2}{*}{10} & $5 \mathrm{~A}$ & $2 \mathrm{PS}, 3 \mathrm{VS}$ & III-IV \\
\hline & $3 B$ & $3 \mathrm{VS}$ & |I-III \\
\hline \multirow[t]{2}{*}{11} & $5 A$ & $5 \mathrm{PS}$ & II-V \\
\hline & $4 \mathrm{~B}$ & $4 \mathrm{VS}$ & |I-III \\
\hline \multirow[t]{2}{*}{12} & $13 \mathrm{~A}$ & $8 \mathrm{PS}, 5 \mathrm{VS}$ & II-V \\
\hline & $5 \mathrm{~B}$ & $5 \mathrm{VS}$ & III-IV \\
\hline \multirow[t]{2}{*}{13} & $13 \mathrm{~A}$ & 12PS,1VS & II-V \\
\hline & $4 \mathrm{~B}$ & 4VS & II-V \\
\hline \multirow[t]{2}{*}{24} & $23 \mathrm{~A}$ & 16PS,7VS & III-V \\
\hline & $9 \mathrm{~B}$ & 9VS & II-V \\
\hline \multirow[t]{2}{*}{26} & $34 \mathrm{~A}$ & 22PS,11VS,1CL & II-V \\
\hline & $16 \mathrm{~B}$ & 1PS,15VS & II-V \\
\hline \multirow[t]{2}{*}{29} & $31 \mathrm{~A}$ & 25PS,6VS & II-V \\
\hline & $17 \mathrm{~B}$ & $17 \mathrm{VS}$ & II-V \\
\hline \multirow[t]{2}{*}{33} & $14 \mathrm{~A}$ & 7PS,6VS,1CL & II-V \\
\hline & $6 \mathrm{~B}$ & $6 \mathrm{VS}$ & II-V \\
\hline
\end{tabular}

VS: virilizante simples, PS: perdedor de sal, CL: forma clássica, ND: dado não disponível. SNP 2: $C Y P 3 A 7^{*} 1 \mathrm{C}$, SNP 8: $C Y P 3 A 7^{*} 2$, SNP 10: rs45515892, SNP 11: rs45446903, SNP 12: rs41279866, SNP 13: rs45600842, SNP 24: rs2276707, SNP 26: rs2307424, SNP 29: rs2502815, SNP 33: rs2307418. 
As análises de correlação das variantes dos genes CYP3A7, PXR e CAR, assim como o genótipo $210 \mathrm{H}$, com o Prader score estão demonstradas com o $P, \mathrm{R}$ e $r^{2}$ na Tabela 14, não levando em consideração os grupos genotípicos A e B. Estas análises foram feitas também em cada genótipo 21OH, Tabelas 15 e 16.

Apesar da significância estatística da associação entre o Prader score (variável dependente) e o genótipo da $210 \mathrm{H}$, este último explicou somente $9 \%$ da variabilidade fenotípica $\left(P<0,001 ; r^{2}=0,0967\right)$. Nas análises uni-variadas nenhuma substituição dos genes CYP3A7, PXR e CAR apresentaram associação significante com o Prader score. No entanto, diversos modelos multi-variados foram testados, incluindo-se simultaneamente os genótipos $210 \mathrm{H}$ e as variantes dos genes CYP3A7, PXR e CAR, foi observado que o SNP 26 do gene CAR junto com o genótipo $21 \mathrm{OH}$ justificou $25 \%$ da variabilidade do Prader score $\left(P=0,023 ; r^{2}=0,253\right)$.

Analisamos o SNP 26 no site de predição Human Splicing Finder versão 2.4.1, disponível em: http://www.umd.be/HSF/ (Desmet et al 2009), e a variante "quebrou" dois sítios de ligação para ESEs (exonic splicing enhancers) e criou 3 novos sítios para EIEs (exon-identity elements) e 4 para IIEs (intron-identity elements), em relação ao alelo selvagem. Mostrando que o SNP 26 está localizado em um sítio importante de reconhecimento de splicing. 
Tabela 14. Regressão linear uni-variada do genótipo $210 \mathrm{H}$ e dos SNPs dos genes CYP3A7, PXR e CAR com o Prader score como variável dependente.

\begin{tabular}{cccc}
\hline $\begin{array}{c}\text { Variável } \\
\text { independente }\end{array}$ & $\mathbf{R}$ & $\mathbf{r}^{2}$ & $\boldsymbol{P}$ \\
\hline Genótipo 21OH & 0,31 & 0,0967 & $<0,001$ \\
SNP 2 & 0,01 & 0,0001 & 0,877 \\
SNP 8 & 0,07 & 0,005 & 0,389 \\
SNP 10 & 0,02 & 0,0005 & 0,794 \\
SNP 11 & 0,07 & 0,005 & 0,421 \\
SNP 12 & 0,05 & 0,002 & 0,573 \\
SNP 13 & 0,02 & 0,0002 & 0,853 \\
SNP 24 & 0,07 & 0,005 & 0,498 \\
SNP 26 & 0,09 & 0,009 & 0,366 \\
SNP 29 & 0,08 & 0,006 & 0,462 \\
SNP 33 & 0,06 & 0,004 & 0,554 \\
\hline SNP 2: CYP3A7 1C, SNP 8: CYP3A7 2, SNP 10: rs45515892, SNP 11: \\
rs45446903, SNP 12: rs41279866, SNP 13: rs45600842, SNP 24: \\
rs2276707, SNP 26: rs2307424, SNP 29: rs2502815, SNP 33: rs2307418.
\end{tabular}

Tabela 15. Regressão linear uni-variada dos SNPs do gene CYP3A7 em cada grupo genotípico $21 \mathrm{OH}$ (A e B), com o Prader score como variável dependente.

\begin{tabular}{ccccccc}
$\begin{array}{c}\text { Genótipo } \\
\text { 210H }\end{array}$ & SNP 2 & SNP 8 & SNP 10 & SNP 11 & SNP 12 & SNP 13 \\
\hline $\mathrm{A}$ & $\mathrm{r}^{2}=0,0003$ & $\mathrm{r}^{2}=0,001$ & $\mathrm{r}^{2}=0,0009$ & $\mathrm{r}^{2}=0,0009$ & $\mathrm{r}^{2}=0,02$ & $\mathrm{r}^{2}=0,01$ \\
& $P=0,844$ & $P=0,727$ & $P=0,778$ & $P=0,778$ & $P=0,163$ & $P=0,332$ \\
$\mathrm{~B}$ & $\mathrm{r}^{2}=0,006$ & $\mathrm{r}^{2}=0,03$ & $\mathrm{r}^{2}=0,009$ & $\mathrm{r}^{2}=0,03$ & $\mathrm{r}^{2}=0,01$ & $r^{2}=0,05$ \\
& $P=0,568$ & $P=0,245$ & $P=0,522$ & $P=0,235$ & $P=0,473$ & $P=0,154$ \\
\hline
\end{tabular}

SNP 2: CYP3A7*1C, SNP 8: CYP3A7*2, SNP 10: $r s 45515892$, SNP 11: $r s 45446903$, SNP 12: rs41279866, SNP 13: rs45600842.

Tabela 16. Regressão linear uni-variada dos SNPs dos genes $P X R$ e $C A R$ em cada grupo genotípico $210 \mathrm{OH}$ (A e B), com o Prader score como variável dependente.

\begin{tabular}{ccccc}
\hline $\begin{array}{c}\text { Genótipo } \\
\text { 210H }\end{array}$ & SNP 24 & SNP 26 & SNP 29 & SNP 33 \\
\hline A & $r^{2}=0,007$ & $r^{2}=0,003$ & $r^{2}=0,005$ & $r^{2}=0,0009$ \\
& $P=0,510$ & $P=0,690$ & $P=0,588$ & $P=0,813$ \\
$B$ & $r^{2}=0,002$ & $r^{2}=0,04$ & $r^{2}=0,00004$ & $r^{2}=0,01$ \\
& $P=0,818$ & $P=0,278$ & $P=0,973$ & $P=0,542$ \\
\hline
\end{tabular}

SNP 24: rs2276707, SNP 26: rs2307424, SNP 29: rs2502815, SNP 33: rs2307418. 


\subsection{P450 Óxido-Redutase}

Os exons $12-13$ do gene $P O R$ foram sequenciados para rastrear a variante funcional A503V em 172 pacientes e foi identificada em 68 pacientes em heterozigose e em 9 pacientes em homozigose, com frequência alélica de $25 \%$.

\subsection{7-Hidroxiesteróide Desidrogenase Tipo 5}

A região promotora do gene HSD17B5 foi sequenciada para rastrear a variante funcional -71G em 159 pacientes e foi identificada em 73 pacientes em heterozigose e em 16 pacientes em homozigose, com frequência alélica de $33 \%$.

Foi identificada a variante polimórfica (rs2518047) em heterozigose em 44 pacientes e em homozigose em 5 pacientes, com frequência alélica de $17 \%$.

A deleção ATTAT/- (rs72550798) foi identificada em apenas duas pacientes com genótipo A: paciente 65 com Prader IV e paciente 7718 com Prader III.

\subsection{Enzima 5a-Redutase}

O exon 1 do gene SRD5A2 foi amplificado para rastrear as variantes funcionais V89L e A49T em 167 pacientes. A variante V89L SRD5A2 foi identificada em 68 pacientes em heterozigose e em 17 pacientes em homozigose, com frequência alélica de $31 \%$.

A variante A49T SRD5A2 foi identificada em 4 pacientes em heterozigose, com frequência alélica de 1\%, e todas elas apresentaram Prader score III. 


\subsection{Correlação das Variantes Funcionais A503V POR, -71G HSD17B5, V89L SRD5A2 e A49T SRD5A2 com o Grau de Virilização Genital}

A distribuição das variantes funcionais de acordo com o genótipo $210 \mathrm{H}$, forma clínica e Prader score está descrita na Tabela 17.

Tabela 17. Distribuição das variantes encontradas nos genes POR, HSD17B5 e SRD5A2 de acordo com o genótipo $210 \mathrm{H}$, forma clínica e com o grau de virilização nas pacientes com hiperplasia adrenal congênita.

\begin{tabular}{|c|c|c|c|c|c|c|}
\hline SNP & Variante & NCBI & n (\%) & $\begin{array}{c}\text { Genótipo } \\
210 \mathrm{H}\end{array}$ & $\begin{array}{l}\text { Forma } \\
\text { clínica }\end{array}$ & $\begin{array}{c}\text { Prader } \\
\text { score }\end{array}$ \\
\hline \multirow[t]{2}{*}{35} & A503V POR & $r s 1057868$ & $78(25)$ & $48 \mathrm{~A}$ & 37PS,6VS,5CL & II-V \\
\hline & & & & $30 \mathrm{~B}$ & $4 \mathrm{PS}, 24 \mathrm{VS}, 2 \mathrm{CL}$ & I-IV \\
\hline \multirow[t]{2}{*}{36} & $-71 G$ & $r s 3763676$ & $93(33)$ & $60 \mathrm{~A}$ & 45PS,10VS,5CL & II-V \\
\hline & HSD17B5 & & & 33B & 4PS,25VS,4CL & $\mathrm{I}-\mathrm{V}$ \\
\hline \multirow[t]{2}{*}{37} & $-210 C$ & $r s 2518047$ & $49(17)$ & $31 \mathrm{~A}$ & 28PS,3VS & II-V \\
\hline & HSD17B5 & & & $14 \mathrm{~B}$ & $2 \mathrm{PS}, 12 \mathrm{VS}$ & II-V \\
\hline \multirow[t]{2}{*}{38} & V89L & $r s 523349$ & $87(30)$ & $57 \mathrm{~A}$ & 43PS,11VS,3CL & II-V \\
\hline & $S R D 5 A 2$ & & & $30 \mathrm{~B}$ & 2PS,25VS,3CL & II-V \\
\hline \multirow[t]{2}{*}{39} & A49T & $r s 9282858$ & $4(1)$ & $2 A$ & 1PS,1VS & III \\
\hline & $S R D 5 A 2$ & & & $2 \mathrm{~B}$ & 2VS & III \\
\hline
\end{tabular}

PS: forma clássica perdedora de sal, VS: forma clássica virilizante simples, CL: forma clássica.

As frequências dos SNPs 35, 36 e 38 de acordo com o Prader score em cada grupo genotípico 21OH (A e B) estão representadas nas Figuras 16 e 17. 


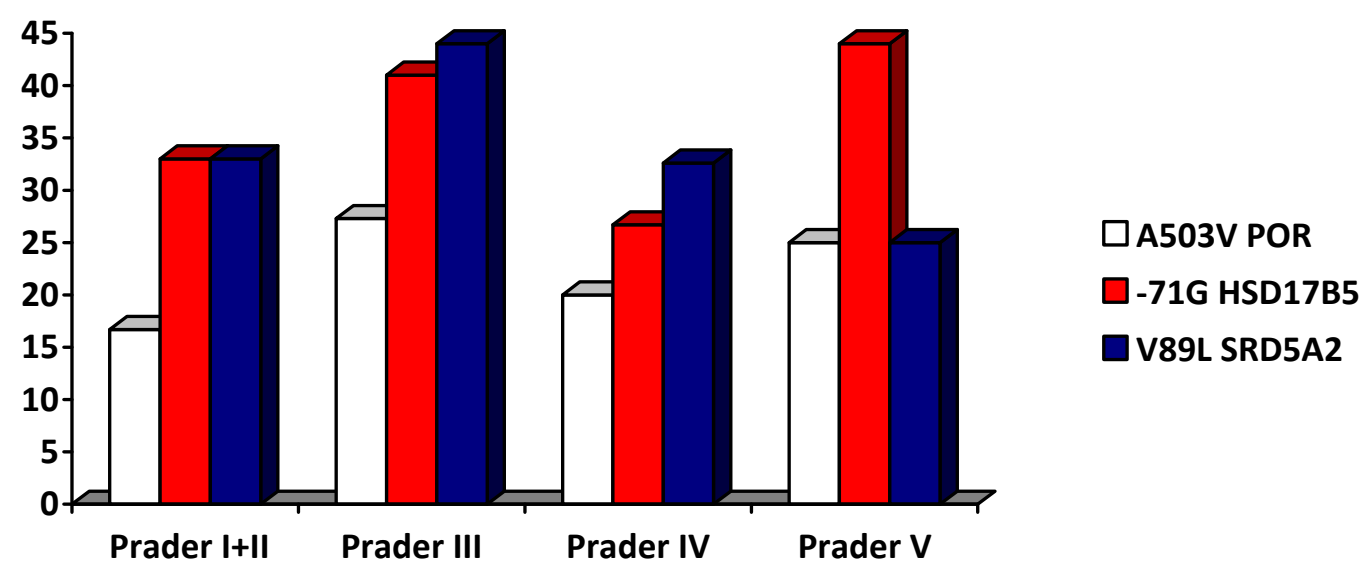

Figura 16. Frequências das variantes A503V POR, -71G HSD17B5 e V89L SRD5A2 de acordo com o Prader score em pacientes com genótipo $210 \mathrm{OH}$ do grupo $\mathrm{A}$.

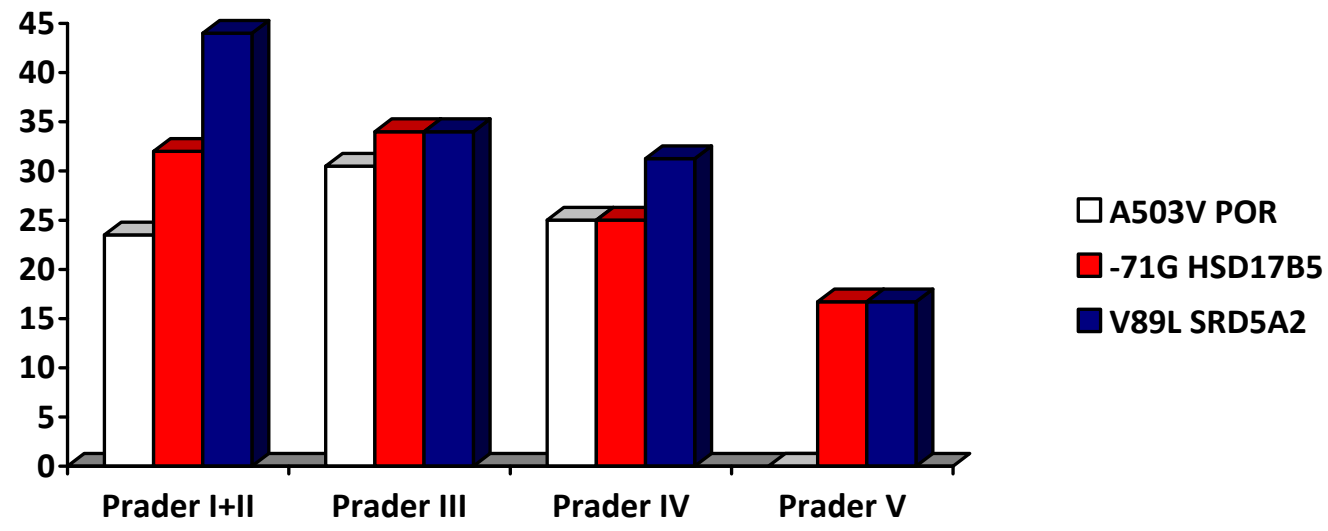

Figura 17. Frequências das variantes A503V POR, -71G HSD17B5 e V89L SRD5A2 de acordo com o Prader score em pacientes com genótipo $210 \mathrm{OH}$ do grupo $B$. 


\subsection{Receptor Androgênico}

O número de repetições CAG (nCAG) do receptor androgênico foi avaliado em 162 pacientes e $83 \%$ delas foram heterozigotas. O nCAG apresentou uma distribuição normal nos dois grupos genotípicos $210 \mathrm{H}, \mathrm{A}$ e B (Figura 18).

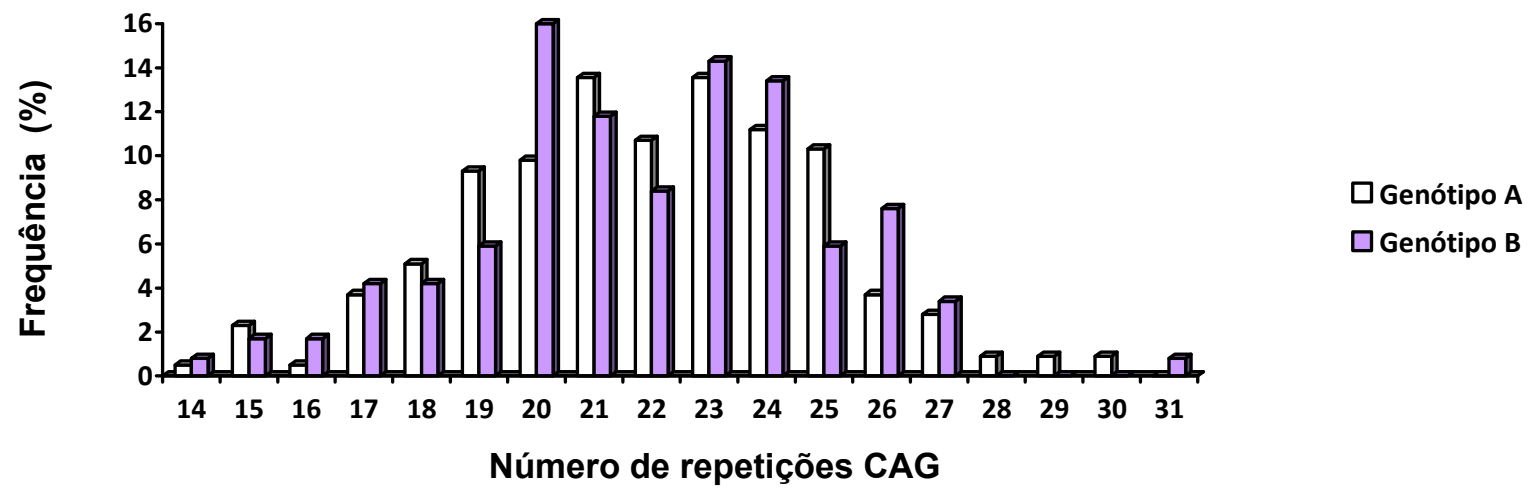

Figura 18. Distribuição do número de repetições $C A G$ do gene receptor androgênico das pacientes com hiperplasia adrenal congênita de acordo com o genótipo 21OH (A e B).

\subsubsection{Comparação do nCAG com o grau de virilização genital}

A média do número de repetições CAG não diferiu nas pacientes carreadoras do genótipo A entre os diversos grupos de Prader score $(P=$ 0,605) e também não diferiu nas carreadoras do genótipo $B(P=0,923)$, Figuras 19 e 20. 


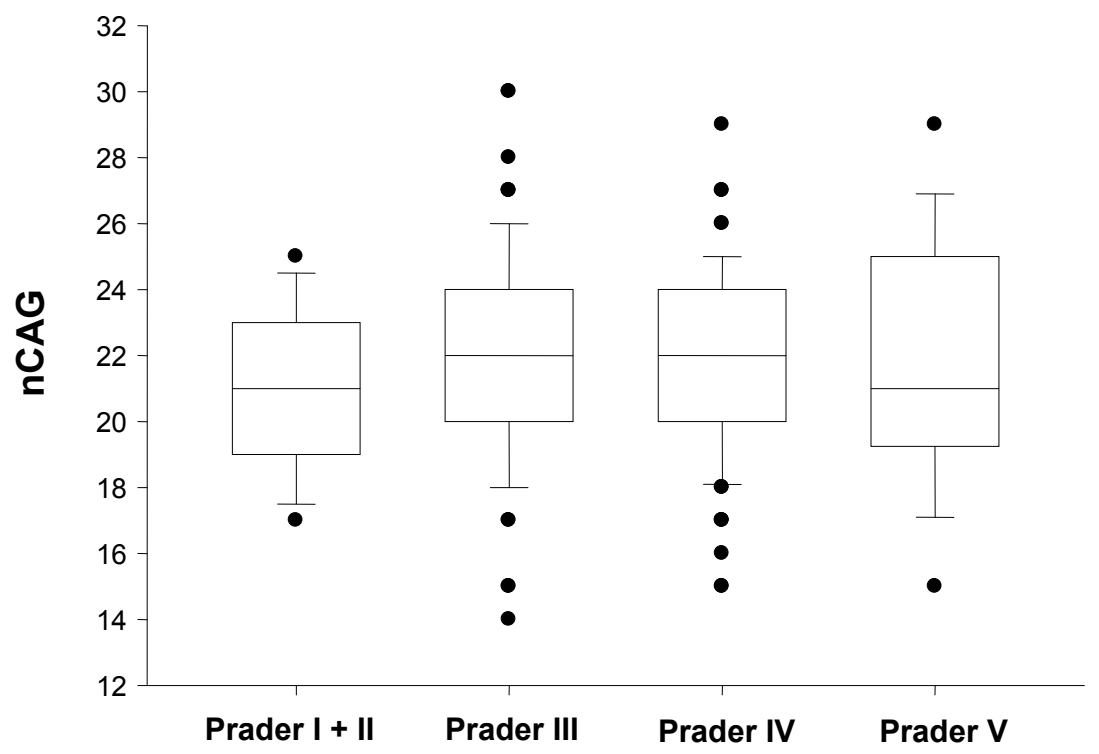

Figura 19. Distribuição do número de repetições CAG do receptor androgênico de acordo com o Prader score de pacientes com hiperplasia adrenal congênita carreando genótipo $210 \mathrm{OH}(P=0,605)$.

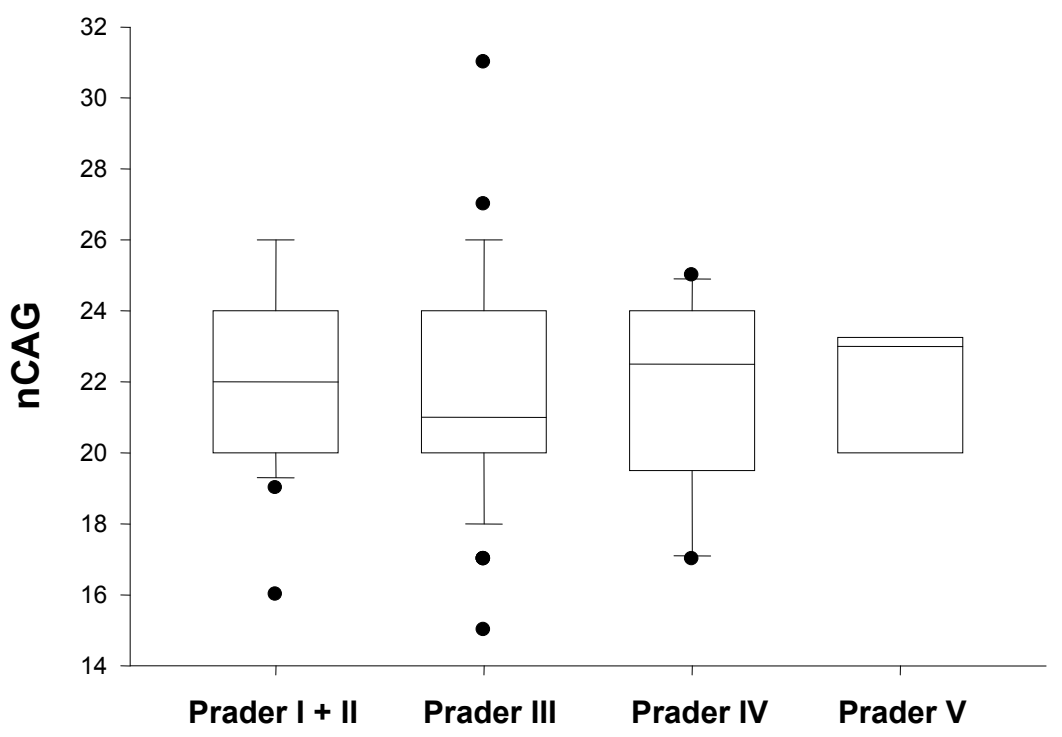

Figura 20. Distribuição do número de repetições CAG do receptor androgênico de acordo com o Prader score de pacientes com hiperplasia adrenal congênita carreando genótipo $210 H B(P=0,923)$. 
Foram avaliadas as frequências dos alelos curtos ( $\leq 18$ repetições $C A G)$ e longos ( $\geq 26$ repetições CAG) de acordo com o Prader score nas pacientes com genótipo $210 \mathrm{H}$ A e B e não foram identificadas diferenças significativas (Tabela 18).

Tabela 18. Frequências dos alelos curtos e longos do nCAG do gene receptor androgênico de acordo com o Prader score nas pacientes com hiperplasia adrenal congênita divididas nos grupos genotípicos A e B.

\begin{tabular}{|c|c|c|c|c|c|c|c|c|}
\hline \multirow[t]{2}{*}{$\begin{array}{c}\text { Genótipo } \\
210 H\end{array}$} & \multicolumn{4}{|c|}{$\begin{array}{c}\text { alelo curto (\%) } \\
\text { ( } \leq 18 \mathrm{nCAG})\end{array}$} & \multicolumn{4}{|c|}{$\begin{array}{c}\text { alelo longo (\%) } \\
(\geq 26 \text { nCAG) }\end{array}$} \\
\hline & $|+| \mid$ & III & IV & $\mathbf{V}$ & $|+| \mid$ & III & IV & V \\
\hline A & 29 & 23 & 17 & 37 & 0 & 20 & 12 & 25 \\
\hline B & 9 & 19 & 40 & 33 & 18 & 19 & 0 & 0 \\
\hline
\end{tabular}

\subsection{Correlação das Variantes Funcionais A503V POR, -71G HSD17B5, V89L SRD5A2 e nCAG do RA com o Grau de Virilização Genital}

A análise das variantes A503V POR, -71G HSD17B5, V89L SRD5A2, rs2518047, alelos curto e longo do nCAG RA, assim como o genótipo da $210 \mathrm{H}$, com o Prader score estão demonstradas com o $P, \mathrm{R}$ e $\mathrm{r}^{2}$ na Tabela 19. Estas análises foram feitas também em cada grupo genotípico $210 \mathrm{H}, \mathrm{A}$ e B, como demonstrado na Tabela 20.

Nas análises uni-variadas, além dos genótipos $21 \mathrm{OH}$, que influenciaram o Prader score $\left(P<0,001 ; r^{2}=0,0967\right)$, explicando $9 \%$ da variabilidade fenotípica, como já mencionado anteriormente, o SNP 37 do gene $\operatorname{HSD17B5}\left(P=0,01 ; \mathrm{r}^{2}=0,0419\right)$ também influenciou o Prader score, explicando 4\% da variabilidade fenotípica.

Nos modelos de análise multi-variadas, utilizando-se as variáveis genótipo $210 \mathrm{H}$ e os SNPs dos genes POR, HSD17B5, SRD5A2 e RA, o SNP 37 do gene HSD17B5 
manteve associação significativa $\left(P=0,006 ; r^{2}=0,144\right)$, explicando $14 \%$ da variabilidade do Prader score.

Analisamos o SNP 37 no site de predição Genomatix MatInspector, disponível em: http://www.genomatix.de/cgi-bin//matinspector_prof (Cartharius et al 2005), a variante criou um novo sitio de ligação ao complexo HOX-PBX, especificamente ao fator de transcrição Meis Homeobox 1 (MEIS1: myeloid ecotropic viral integration site 1 homologue), em relação ao alelo selvagem.

Tabela 19. Regressão linear uni-variada das variantes encontradas nos genes POR, HSD17B5, SRD5A2 e alelo curto e longo nCAG RA com o Prader score como variável dependente.

\begin{tabular}{cccc}
\hline $\begin{array}{c}\text { Variável } \\
\text { independente }\end{array}$ & $\mathbf{R}$ & $\mathbf{r}^{2}$ & $\boldsymbol{P}$ \\
\hline Genótipo 21OH & 0,31 & 0,0967 & $<0,001$ \\
SNP 35 & 0,103 & 0,01 & 0,18 \\
SNP 36 & 0,129 & 0,02 & 0,105 \\
SNP 37 & 0,205 & 0,04 & 0,01 \\
SNP 38 & 0,007 & 0,00005 & 0,931 \\
alelo curto CAG & 0,04 & 0,002 & 0,598 \\
alelo longo CAG & 0,04 & 0,002 & 0,583 \\
\hline
\end{tabular}

SNP 35: A503V POR, SNP 36: -71G HSD17B5, SNP 37: rs2518047 e SNP 38: V89L SRD5A2.

Tabela 20. Análise de regressão linear uni- variada das variantes encontradas nos genes $P O R$, HSD17B5, SRD5A2 e alelo curto e longo nCAG RA de acordo com os grupos genotípicos A e B.

\begin{tabular}{ccccccc}
$\begin{array}{c}\text { Genótipo2 } \\
\text { 10H }\end{array}$ & SNP 35 & SNP 36 & SNP 37 & SNP 38 & $\begin{array}{c}\text { alelo curto } \\
\text { CAG }\end{array}$ & $\begin{array}{c}\text { alelo longo } \\
\text { CAG }\end{array}$ \\
\hline A & $r^{2}=0,003$ & $r^{2}=0,02$ & $r^{2}=0,04$ & $r^{2}=0,0002$ & $r^{2}=0,0004$ & $r^{2}=0,0002$ \\
& $P=0,583$ & $P=0,152$ & $P=0,030$ & $P=0,874$ & $P=0,838$ & $P=0,878$ \\
B & $r^{2}=0,03$ & $r^{2}=0,04$ & $r^{2}=0,06$ & $r^{2}=0,002$ & $r^{2}=0,02$ & $r^{2}=0,03$ \\
& $P=0,242$ & $P=0,150$ & $P=0,102$ & $P=0,738$ & $P=0,354$ & $P=0,218$ \\
\hline SNP 35: A503V POR, SNP 36: -71G HSD17B5, SNP 37: $r$ S2518047 e SNP 38: V89L SRD5A2.
\end{tabular}

As frequências do SNP 26 do gene CAR e SNP 37 do gene HSD17B5, que apresentaram correlação significante com o Prader score nas análises multi-variadas, estão demonstradas na Figura 21. Observa-se aumento da frequência destes SNPs 
conforme ocorre aumento da virilização genital, exceto pelo SNP 26 no grupo com Prader score I + II.

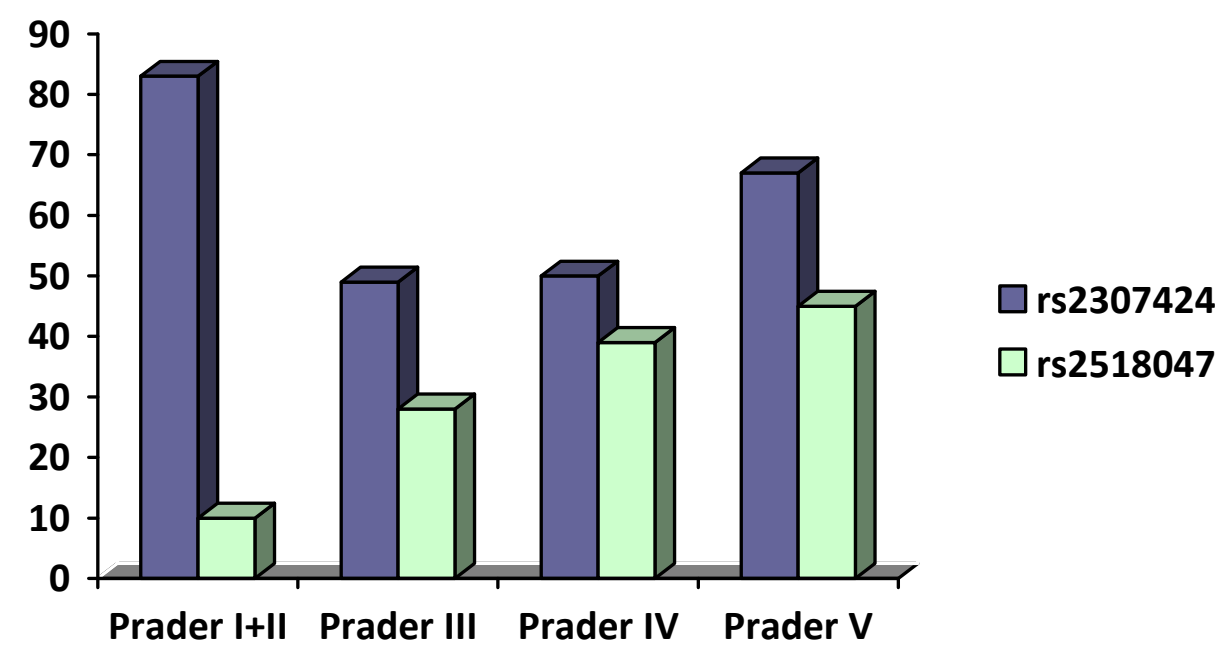

Figura 21. Frequências do SNP 26: rs2307424 CAR e SNP 37: rs2518047 HSD17B5 de acordo com o Prader score em pacientes com genótipo 210H A e B junto. SNP 26: $P$ I+II $(n=12), P$ III $(n=45), P$ IV $(n=28), P \vee(n=6) ;$ SNP 37: P I+II $(n=20), P$ III $(n=77), P$ IV $(n=51), P \vee:(n=11)$

Por último, foram analisados pacientes nos quais o grau de virilização genital foi discordante do esperado para os genótipos $210 \mathrm{H}$. Foram encontrados nesta casuística 9 casos com genótipo A e leve virilização genital (Prader score II) e 9 casos com genótipo B e com importante virilização genital (Prader score IV e V), Tabela 21. Nesta amostra, nenhuma das variantes influenciou o grau de virilização genital. 
Tabela 21. Casos discordantes entre os genótipos $210 \mathrm{H}$ e o grau de virilização genital em mulheres com hiperplasia adrenal congênita.

\begin{tabular}{|c|c|c|c|c|c|c|c|c|}
\hline DNA & $\begin{array}{c}\text { Genótipo } \\
210 \mathrm{OH}\end{array}$ & Prader & SNP 26 & SNP 35 & SNP 36 & SNP 37 & SNP 38 & $\begin{array}{c}\text { nCAG } \\
R A\end{array}$ \\
\hline $39^{1}$ & $\bar{A}$ & II & $\mathrm{mt} / \mathrm{mt}$ & $\mathrm{wt} / \mathrm{wt}$ & $\mathrm{wt} / \mathrm{wt}$ & $\mathrm{wt} / \mathrm{wt}$ & $\mathrm{wt} / \mathrm{mt}$ & $19 / 25$ \\
\hline $2956^{1}$ & A & II & $\mathrm{wt} / \mathrm{mt}$ & $w t / w t$ & $\mathrm{wt} / \mathrm{mt}$ & $\mathrm{wt} / \mathrm{mt}$ & $\mathrm{wt} / \mathrm{mt}$ & $19 / 23$ \\
\hline $6227^{1}$ & A & II & - & $\mathrm{wt} / \mathrm{mt}$ & $\mathrm{wt} / \mathrm{mt}$ & wt/wt & $w t / w t$ & $19 / 23$ \\
\hline $8^{2}$ & A & II & - & $\mathrm{wt} / \mathrm{mt}$ & wt/wt & wt/wt & wt/wt & $17 / 24$ \\
\hline $18^{2}$ & A & II & - & wt/wt & $\mathrm{wt} / \mathrm{mt}$ & $w t / w t$ & wt/wt & $19 / 23$ \\
\hline $26^{2}$ & A & II & - & wt/wt & $\mathrm{wt} / \mathrm{mt}$ & $w t / w t$ & $\mathrm{wt} / \mathrm{mt}$ & $21 / 21$ \\
\hline $29^{2}$ & A & II & - & $\mathrm{wt} / \mathrm{wt}$ & $\mathrm{wt} / \mathrm{mt}$ & $\mathrm{wt} / \mathrm{wt}$ & $\mathrm{wt} / \mathrm{mt}$ & $21 / 23$ \\
\hline $34^{2}$ & A & II & - & wt/wt & $\mathrm{wt} / \mathrm{mt}$ & wt/wt & $\mathrm{wt} / \mathrm{mt}$ & $18 / 23$ \\
\hline $7722^{3}$ & A & II & - & $\mathrm{wt} / \mathrm{mt}$ & wt/wt & wt/wt & $\mathrm{wt} / \mathrm{mt}$ & $23 / 27$ \\
\hline $158^{1}$ & B & IV & wt/wt & wt/wt & $\mathrm{wt} / \mathrm{mt}$ & $\mathrm{wt} / \mathrm{mt}$ & $\mathrm{wt} / \mathrm{wt}$ & $18 / 20$ \\
\hline $266^{1}$ & B & IV & $\mathrm{wt} / \mathrm{mt}$ & $\mathrm{wt} / \mathrm{mt}$ & $\mathrm{wt} / \mathrm{mt}$ & wt/wt & $\mathrm{wt} / \mathrm{mt}$ & - \\
\hline $2814^{1}$ & B & IV & wt/wt & wt/wt & $w t / w t$ & $w t / w t$ & $\mathrm{wt} / \mathrm{wt}$ & $17 / 24$ \\
\hline $6^{2}$ & B & IV & - & wt/wt & $\mathrm{wt} / \mathrm{mt}$ & $\mathrm{wt} / \mathrm{mt}$ & $\mathrm{wt} / \mathrm{mt}$ & $23 / 25$ \\
\hline $17^{2}$ & B & IV & - & $\mathrm{wt} / \mathrm{mt}$ & $\mathrm{wt} / \mathrm{wt}$ & $\mathrm{wt} / \mathrm{mt}$ & $\mathrm{wt} / \mathrm{wt}$ & $24 / 24$ \\
\hline $31^{2}$ & B & IV & - & wt/wt & wt/wt & $\mathrm{wt} / \mathrm{mt}$ & $\mathrm{mt} / \mathrm{mt}$ & $22 / 22$ \\
\hline $3958^{1}$ & B & V & $\mathrm{wt} / \mathrm{mt}$ & wt/wt & $w t / w t$ & $\mathrm{wt} / \mathrm{mt}$ & $\mathrm{wt} / \mathrm{mt}$ & $23 / 23$ \\
\hline $20^{2}$ & B & V & - & wt/wt & $w t / w t$ & $w t / w t$ & $w t / w t$ & $21 / 24$ \\
\hline $7485^{4}$ & B & V & - & wt/wt & $\mathrm{wt} / \mathrm{mt}$ & wt/wt & $\mathrm{wt} / \mathrm{wt}$ & $17 / 23$ \\
\hline
\end{tabular}

\subsection{Expressão Gênica}

A quantificação da expressão dos genes HSD17B5, SRD5A1, SRD5A2 e RA no fragmento de pele genital de cada paciente estudada está descrita na Tabela 22.

Identificou-se um aumento da expressão do gene da 5a-redutase tipo II (SRD5A2) em 4 das 7 pacientes com virilização genital Prader score IV. Por outro lado, somente 1 das 5 pacientes com Prader score III apresentou uma expressão aumentada do gene SRD5A2; porém, a magnitude deste aumento foi menor do que a observada nas pacientes com Prader score IV. Contudo, não houve diferença 
significativa na comparação da expressão do gene SRD5A2 entre as pacientes com Prader score III e IV $(P=0,149)$.

A expressão dos genes HSD17B5, SRD5A1 e RA também não diferiram entre os grupos de Prader score III e IV.

Tabela 22. Expressão dos genes HSD17B5, SRD5A1, SRD5A2 e RA no tecido de pele genital das 12 pacientes com hiperplasia adrenal congênica.

\begin{tabular}{cccccc}
\hline DNA & $\begin{array}{c}\text { Prader } \\
\text { score }\end{array}$ & HSD17B5 & SRD5A1 & SRD5A2 & RA \\
\hline 103 & III & 1,72 & 2,67 & 0,33 & 0,59 \\
7891 & III & 1,05 & 2,23 & 3,25 & 1,85 \\
2975 & III & 0,56 & 0,69 & 1,67 & 0,39 \\
3633 & III & 0,85 & 0,49 & 0,98 & 0,69 \\
437 & III & 0,41 & 0,16 & 0,005 & 0,80 \\
\hline 5610 & IV & 1,49 & 0,17 & 5,41 & 2,05 \\
3001 & IV & 0,41 & 0,29 & 0,8 & 0,29 \\
1732 & IV & 1,08 & 0,15 & 31,8 & 2,05 \\
1875 & IV & 0,65 & 0,42 & 6,2 & 0,65 \\
219 & IV & 2,08 & 1,06 & 1,13 & 0,98 \\
3396 & IV & 5,54 & 0,39 & 19,5 & 4,41 \\
8280 & IV & 0,30 & 0,57 & 0,85 & 0,35 \\
\hline$P$ & & 0,409 & 0,202 & 0,149 & 0,355 \\
\hline
\end{tabular}


7. DISCUSSÃO 
A forma clássica da hiperplasia adrenal congênita por deficiência da 21hidroxilase é a causa mais frequente de distúrbios do desenvolvimento sexual (DDS) 46,XX em todos os grupos étnicos (White \& Speiser 2000). Esta doença é causada por mutações no gene CYP21A2 e, atualmente, mais do que 150 mutações de ponto já foram descritas; contudo, nove delas são as mais frequentes nas diversas populações (http://www.cypalleles.ki.se/cyp21.htm) (White \& Speiser 2000). Embora a deficiência da 21-hidroxilase seja uma doença de etiologia monogênica, observase uma variedade de formas clínicas, as quais representam um espectro no comprometimento da atividade enzimática decorrentes da presença das diferentes mutações no gene da 21-hidroxilase. Sabe-se que na HAC $210 \mathrm{H}$ existe uma forte correlação do genótipo com as formas clínicas e com os valores hormonais (Speiser et al 1992, Wedell et al 1994, Krone et al 2000, Finkielstain et al 2011); entretanto, esta correlação não se estende ao grau de virilização genital (Giwercman et al 2002, Rocha et al 2008).

A fim de avaliar esta discordância na correlação genótipo/fenótipo fizemos este estudo com uma casuística expandida, possibilitada pela realização de estudo multicêntrico. Esta análise iniciou pela determinação do genótipo das pacientes e em concordância com os dados de trabalhos prévios em diversas populações com a forma clássica, encontramos uma frequência maior de mutações que resultam em comprometimento grave da atividade da enzima 210H (Finkielstain et al 2011, Marino et al 2011). Como esperado, observamos que estas mutações apresentaram forte correlação com a forma perdedora de sal, enquanto que as mutações que predizem comprometimento moderado se correlacionaram com a forma virilizante simples. Avaliamos também a correlação do genótipo com as concentrações basais 
hormonais ao diagnóstico e, novamente, a gravidade do genótipo influenciou estas concnetrações. Pacientes carreadoras do genótipo mais grave (grupo A) tiveram concentrações basais significativamente maiores de androstenediona e de testosterona em relação as carreadoras do genótipo moderado (B). Entretanto, diferentemente do esperado, esta correlação não foi observada com as concentrações basais de $170 \mathrm{H}$-progesterona; supomos que este último resultado possa ter sido decorrente da utilização de dados retrospectivos que foram obtidos por diversas metodologias neste estudo multicêntrico.

$\mathrm{Na}$ análise da correlação do genótipo com o grau de virilização genital, o presente estudo representa a continuidade de trabalho anterior desenvolvido em nosso serviço, que envolveu 85 pacientes com a forma clássica (Rocha et al 2008). Neste trabalho inicial não identificamos uma influência do genótipo no fenótipo genital. Entretanto, em recente estudo multicêntrico europeu, que compreendeu 158 mulheres com a forma clássica, foi observado que genótipos mais graves se associavam à quadros de virilização mais intensos (Welzel et al 2010). Similarmente, com o aumento da casuística, neste estudo multicêntrico de pacientes brasileiras também observamos a influência do genótipo no fenótipo genital. Contudo, apesar desta associação significativa, o genótipo explicou apenas $9 \%$ da variabilidade do Prader score. Observamos que na nossa casuística, assim como na do estudo europeu, que permanece uma grande variabilidade do grau de virilização genital em pacientes carreando genótipos que predizem semelhante comprometimento da atividade da $210 \mathrm{H}$.

Considerando que a virilização genital é decorrente da hipersecreção de testosterona adrenal, que perifericamente é convertida em dehidrotestosterona, 
correlacionamos as concentrações de testosterona basal com o Prader score e não identificamos diferenças significativas. Entretanto, gostaríamos de ressaltar que muitas destas pacientes tiveram diagnóstico da deficiência da 21-hidroxilase realizado fora do período neonatal, quando foram obtidas as dosagens de testosterona, fato que pode ter contribuído para esta ausência de correlação. Na literatura já foi observada uma correlação das concentrações de testosterona com o fenótipo genital; entretanto, esta correlação foi no período pós-natal. Na série de 12 pacientes da Indonésia com a forma virilizante simples e com diagnóstico tardio, variando de 1 a 33 anos, foi identificada uma correlação direta das concentrações de testosterona com o crescimento clitoriano pós-natal (Goossens et al 2009).

Esta variabilidade no fenótipo de virilização genital da HAC tem sido discutida na literatura e sugere-se que possa ser consequente de uma variabilidade interindividual na sensibilidade periférica a ação dos andrógenos (Legro et al 1994, Vottero et al 1999, Giwercman et al 2002). Esta variação na sensibilidade individual local poderia ser devida à diferenças na ação, na síntese ou na metabolização androgênica e, é conhecido que parte desta variabilidade é geneticamente determinada (Marioli et al 2009, Schüring et al 2012).

Iniciamos este projeto pela análise do citocromo P450 3A7 considerando que é o principal metabolizador de andrógenos na vida fetal. O CYP3A7 é responsável pela 16a-hidroxilação da DHEA e DHEAS, eliminando a biodisponibilidade dos precursores para a síntese de testosterona (Lee et al 2003, Stevens et al 2003, Miller et al 2004). No seu gene tem sido descritas variantes alélicas que modificam a sua atividade catalítica. A substituição do promotor, $C Y P 3 A 7^{*} 1 \mathrm{C}$, que causa expressão persistente na vida adulta do gene, foi identificada como a principal 
variante dos CYP3As que altera as concentrações androgênicas (Siemes et al 2010). Foi observado in vivo que carreadores desta variante apresentam diminuição significativa nas concentrações de DHEA, androstenediona e estrona em relação às homozigotas selvagens, o que caracteriza que a variante se associa a um fenótipo ultra-metabolizador. Em concordância com esta hipótese, na casuística do HCFMUSP em estudo anterior, o alelo CYP3A7*1C foi associado com a necessidade de doses menores na terapia de reposição com glicocorticoide no tratamento da HAC em relação aos pacientes carreadores do alelo selvagem. A hipótese é a de que as pacientes carreadoras deste alelo necessitem de doses menores por apresentarem metabolismo hepático aumentado dos andrógenos adrenais (Moreira et al 2011).

No presente trabalho, as variantes da região promotora do gene CYP3A7, em concordância com os dados da literatura, tiveram frequência muito baixa (Burk et al 2002). O alelo CYP3A7*1C não se correlacionou com uma menor virilização da genitália externa, possivelmente pelo pequeno número de pacientes carreadoras deste alelo.

Outra variante descrita, que altera o metabolismo androgênico, é a substituição missense denominada por $C Y P 3 A 7^{*} 2$, caracterizada por aumentar a constante catalítica em 1,5 vezes para a 16a-hidroxilação da DHEA e fetos carreadores deste alelo possuem uma via mais ativa para a biotransformação androgênica (Rodriguez-Antona et al 2005a). Consequentemente, hipotetizamos que pacientes com HAC carreadoras do alelo $C Y P 3 A 7^{\star} 2$ poderiam apresentar fenótipos de virilização genital menos intensos. Apesar desta variante ter sido frequente na nossa casuística, o alelo não foi correlacionado com o Prader score. Similarmente 
ao nosso achado, um outro trabalho que avaliou a associação in vivo do alelo CYP3A7*2 com câncer de testículo também não identificaram uma influência direta da substituição com a susceptibilidade individual para a doença (Kristiansen et al 2011).

Como recentemente a literatura tem observado que SNPs na região 5'UTR podem modificar o reconhecimento de sítios de splicing ou alterar a expressão gênica (Surekha et al 2010, Li et al 2011), também estudamos 4 variantes intrônicas do gene CYP3A7 e as correlacionamos com o Prader score, porém, não encontramos resultados com significância estatística.

Outro fator que merece destaque é a observação de que a variabilidade de expressão dos citocromos P450 hepáticos possa ser geneticamente determinada também pela presença de polimorfismos nos seus fatores de transcrição. Foi demonstrado que variantes nos fatores nucleares da família CYP3A, PXR e CAR, causam diferenças na metabolização de andrógenos e/ou compostos farmacológicos (Ikeda et al 2003, He et al 2006, Zhang et al 2008).

Baseando-se no fato de que variantes nos genes $P X R$ e $C A R$ podem aumentar ou reduzir o potencial de oxidação da testosterona, alterando a biodisponibilidade e/ou o potencial da conversão local de T para DHT, supomos que estas variantes poderiam influenciar o quadro de hiperandrogenismo pré-natal das pacientes com HAC. No rastreamento de variantes nos genes $P X R$ e $C A R$, as mutações missense foram raras na nossa casuística. Nas regiões intrônicas do gene $P X R$ encontramos o SNP 24 (rs2276707), que se associa à aumento da expressão do PXR in vitro e aumento da transativação da família CYP3A (Zhang et al 2001), mas que nesta casuística não modulou o fenótipo de virilização da forma clássica. 
No rastreamento do gene CAR não encontramos as mutações missense H246R e L308P descritas por lkeda et al (2005) na população japonesa, as quais se associam a diminuição da transativação da família CYP3A. Contudo, encontramos uma correlação do SNP silencioso 26 (P180P), localizado no exon 4, com o grau de virilização genital de nossas pacientes com HAC, explicando junto com o genótipo 25\% da variabilidade. Observamos uma maior frequência do SNP nas pacientes com os maiores Prader score, exceto no grupo de pacientes com Prader score I + II, podendo ser explicado pelo pequeno número de casos neste grupo.

O mecanismo pelo qual o SNP 26 altera a função da proteína, ainda não foi elucidado, mas a literatura tem dado ênfase a possíveis efeitos das substituições silenciosas, uma vez que elas podem alterar reconhecimento de sítios de splicing (Daidone et al 2011). Deste modo, verificamos o efeito do SNP em site de predição para a modificação dos sítios de splicing, sendo predito que o SNP 26 poderia modificar uma região importante para a ligação de proteínas que fazem o reconhecimento correto do sítio de splicing. Supomos que a presença do SNP no gene CAR poderia causar a tradução de uma proteína anômala e resultar em fenótipo pobre metabolizador, o que explicaria os nossos achados. Em concordância com esta hipótese, um estudo recente mostrou que o SNP 26 se correlacionou com uma maior concentração no plasma de efavirez, e assim uma discontinuação mais precoce do tratamento com este fármaco, indicando uma variabilidade interindividual no metabolismo hepático causada pelo polimorfismo silecioso (Wyen et al 2011). Com relação às demais variantes da região intrônica do gene $C A R$, não identificamos resultados significativos nas análises de correlação com o Prader score. 
Considerando que o comprometimento da atividade da 21-hidroxilase predito pelo genótipo $210 \mathrm{H}$ e o SNP 26 do CAR justificaram apenas $25 \%$ da variabilidade do fenótipo de virilização genital, demos continuidade ao estudo acrescentando a análise de variantes funcionais em genes envolvidos na síntese e/ou ação androgênica. Portanto, pesquisamos variantes funcionais nos genes POR, HSD17B5, SRD5A2 e RA. As frequências alélicas das variantes A503V POR, -71G HSD17B5, V89L SRD5A2 e A49T SRD5A2 foram semelhantes as descritas na literatura na população caucasiana (Zeigler-Johnson et al 2002, Qin et al 2006, Huang et al 2008).

O citocromo P450 óxido-redutase é um doador de elétrons e sua ação é essencial para a síntese de cortisol e de andrógenos. Mutações no gene POR comprometem a síntese de ambos os hormônios e causam ambiguidade genital no sexo masculino (Miller et al 2010). Para este gene tem sido descrita uma variante comum em diversas etnias, a substituição A503V, associada com uma drástica redução da síntese androgênica em até $60 \%$, o que poderia influir no fenótipo genital de nossas pacientes. Porém, observamos que a variante A503V não foi correlacionada com menor virilização genital nesta casuística. Poucas pacientes eram carreadoras homozigotas desta variante e, supomos que, pelo menos no estado de heterozigose, as mudanças na atividade catalítica na síntese de andrógenos possam não ser significantes para modular o fenótipo genital da HAC.

Outro gene de interesse para o nosso estudo é o HSD17B5, nos chamou a atenção os resultados de um trabalho de pacientes com SOP, no qual as pacientes carreadoras da variante -71G HSD17B5 apresentaram concentrações séricas de testosterona significativamente maiores em relação às homozigotas selvagens, 
demonstrando uma importante contribuição do alelo para o hiperandrogenismo (Qin et al 2006, Marioli et al 2009). Porém este achado é contraditório na literatura, pois Petry et al (2007) e Goodarzi et al (2008b) não encontraram associação do SNP em pacientes com pubarca precoce e SOP, respectivamente, com um excesso androgênico. Na nossa casuística, a variante -71G também não influenciou de maneira significatica o hiperandrogenismo pré-natal, uma vez que não se correlacionou com o o Prader score.

Para o rastreamento da substituição $-71 \mathrm{G}$, realizamos o sequenciamento da região promotora do gene $H S D 17 B 5$ e encontramos outra variante que foi muito frequente na nossa casuística e também na população caucasiana, o SNP 37 (rs2518047). Observamos que esta variante influenciou 4\% do Prader score na análise uni-variada nas pacientes com o genótipo do grupo A e 14\% na análise multi-variada com o genótipo $210 \mathrm{H}$ e os demais polimorfismos funcionais. No grupo genotípico B, o SNP 37 não mostrou esta correlação, possivelmente pelo menor número de pacientes encontrados neste grupo. Este SNP foi encontrado com maior frequência nas pacientes com os maiores Prader scores, assim supomos que o SNP 37 possa estar associado à maior síntese de andrógenos nas adrenais e na pele genital durante o período pré-natal.

Qin \& Rosenfield (2005) estudaram a região promotora do gene HSD17B5 e expressaram constructs de diferentes tamanhos em células de tumor adrenal e mostraram que o promotor não possui as sequências CAAT ou TATA box para regular o gene, mas encontraram o sitio de ligação CСТССТССТ essencial para a transcrição do gene. Este sítio situa-se a 144 pares de base downstream ao SNP 37, 
evidenciando que esta é uma região importante para a ligação à fatores de transcrição.

Apesar da região ter sido avaliada, o significado funcional do SNP 37 ainda não foi descrito na literatura, por isso, avaliamos a substituição em site de predição a fatores de transcrição, e encontramos um novo sítio de ligação para o complexo HOX-PBX, especificamente para o fator MEIS1. O fator MEIS1 pertence a superfamília homeodomain de proteínas que se ligam ao DNA e regulam a transcrição de muitos genes essenciais para o desenvolvimento durante a embriogênese (Mojsin \& Stevanovic 2009). Adicionalmente, o complexo PBX-MEIS contribui tanto para ativação quanto para a repressão do gene e tem sido encontrado em diversos tipos de cânceres (Mojsin \& Stevanovic 2009). Devido a estes achados, semelhantemente a variante -71G, o SNP 37 possivelmente aumenta a afinidade à fatores de transcrição, aumentando assim a transcrição do gene e a biossíntese androgênica, resultando na paciente carreadora do SNP uma maior hiperandrogenemia e maior virilização genital.

Outro gene de grande importância é o da enzima 5a-redutase tipo 2, essencial para a conversão da testosterona para a DHT, um potente andrógeno responsável pela virilização pré-natal. Um estudo com pacientes DDS 46,XY mostrou que o polimorfismo V89L SRD5A2, por causar uma diminuição de $30 \%$ na produção de DHT, influenciou o grau de virilização da genitália externa (FernándezCancio et al 2011). Entretanto, nas pacientes com HAC esta influência não foi observada. A variante A49T SRD5A2 foi rara em nossa amostra e as 4 pacientes carreadoras apresentaram Prader score III, impossibilitando a sua correlação. 
Toda ação androgênica, depende da biodisponibilidade dos andrógenos e de sua ação mediada pelo receptor androgênico, sendo ambas essenciais para o desenvolvimento normal da genitália do sexo masculino (Cheon et al 2011). O RA contêm dois tratos de repetições polimórficas, o CAG e o GGN, codificando os aminoácidos glutamina e glicina, respectivamente (Lubahn et al 1988). Para o trato de repetições CAG existem muitos estudos na literatura e observa-se que existe uma correlação inversa entre o número de repetições e a atividade de transativação do receptor (Chamberlain et al 1994, Tut et al 1997). Este trato tem sido fortemente associado ao fenótipo de doenças andrógeno-dependentes, como por exemplo na infertilidade masculina, que se associa com tratos com números maiores de repetições evidenciando uma menor atividade androgênica na etiologia da infertilidade (Tut et al 1997, Nenonen et al 2011). Tratos com número menor de repetições CAG tem sido associados com pubarca precoce idiopática, sugerindo uma maior ação androgênica periférica como fator etiológico (Ibanez et al 2003).

Estes dados nos levaram a analisar se o trato CAG do RA poderia influenciar o grau de virilização genital das pacientes com HAC. Em estudo anterior observamos uma influência do trato na comparação das pacientes com Prader III entre os grupos genotípicos da $210 \mathrm{OH}$ A e B. As pacientes do grupo B apresentaram número de repetições CAG significativamente menores do que as do grupo A Rocha et al (2008). Este achado poderia ser um dos fatores que justificaria porque pacientes com um genótipo da $210 \mathrm{H}$ mais brando poderiam ser tão virilizadas quanto as carreadoras de um genótipo da $210 \mathrm{H}$ mais grave. Porém, Welzel et al (2010), no estudo multicêntrico europeu, não encontraram correlação deste trato com o grau de virilização genital. 
Com os resultados discordantes sobre a influência do trato CAG no fenótipo de virilização da HAC, refizemos a sua análise nesta casuística expandida. Identificamos que o número de repetições CAG variou de 14 a 31 repetições, apresentando distribuição normal. No entanto, na análise das pacientes com HAC observamos que a média do nCAG não influenciou o Prader score em pacientes carreando os diferentes genótipos da $210 \mathrm{H}$. Similarmente, não identificamos diferenças nas frequências de alelos curto e longo entre os diversos grupos de Prader score. Contudo, sabemos que os resultados podem diferir de acordo com o ponto de corte utilizado para a definição de alelos curto e longo. Os números mais utilizados como ponto de corte para a definição de alelos curtos pela literatura foram 20 ou 22 repetições CAG (Chintamani et al 2010, Liu et al 2012). Considerando que estes números estão dentro do intervalo interquartil da curva de normalidade na maioria das populações, não achamos conveniente reproduzir estes desenhos, e optamos por escolher números de corte mais críticos do que os da literatura.

Outro ponto a ser discutido quanto ao estudo do trato CAG é que o gene do receptor androgênico está localizado no cromossomo $X$ e um dos cromossomos $X$ em mulheres é inativado para o equilíbrio gênico. Assim, o padrão de inativação do cromossomo X é um fator importante a ser avaliado (Kaupert et al 2010). Considerando o fato de que no nosso estudo multicêntrico não foi possível se obter amostras de DNA para se realizar o estudo de inativação do cromossomo X, nossos resultados de ausência de correlação do trato do $R A$ devem ser vistos com cautela. Adicionalmente, a determinação da média bialélica do nCAG em DNA de leucócitos periféricos não implica necessariamente que a genitália do embrião tenha o mesmo padrão de metilação do RA (Kaupert et al 2010). 
Embora o genótipo da 210H, o SNP 26 do gene CAR e o SNP 37 do gene HSD17B5 influenciaram o grau de virilização genital, estas variáveis não justificaram todos os casos. Assim, não podemos afastar a hipótese de que diferenças na expressão local dos genes relacionados à ação e/ou síntese periférica de andrógenos também possam influenciar esta variabilidade fenotípica. Durante o desenvolvimento deste projeto foi possível obter amostras de pele genital de doze pacientes submetidas à genitoplastia e analisamos a expressão dos genes da $17 \beta-$ hidróxi-esteróide tipo 5, da 5a-redutase tipos 1 e 2 e do receptor androgênico.

Nossa análise baseou-se nos achados de que os genes HSD17B5, SRD5A1, SRD5A2 e RA são expressos em fibroblastos de pele genital de homens normais (Hope et al 2006, 2007) e que podem apresentar um perfil de expressão diferencial (Holterhus et al 2007), o que poderia explicar a variabilidade da ambiguidade genital de pacientes com HAC. Até o momento, nenhum estudo avaliou a expressão destes genes em pele genital em pacientes com hiperplasia adrenal congênita.

De acordo com a nossa hipótese, observamos que o gene SRD5A2 teve uma super-expressão em 4 das 7 pacientes com Prader score IV. Por outro lado, somente 1 das 5 pacientes com Prader score III apresentou uma expressão um pouco aumentada do gene SRD5A2. Apesar disso, não encontramos diferença significativa na comparação da expressão do gene SRD5A2 entre as pacientes com Prader score III e IV. A expressão dos genes HSD17B5, SRD5A1 e RA também não diferiram significativamente entre os grupos de Prader score III e IV.

Gostaríamos de enfatizar que os estudos de expressão gênica tecidual em fragmento de pele genital, acima citados, avaliaram o perfil gênico em cultura de fibroblastos (Hope et al 2006 e 2007, Holterhus et al 2007). No nosso conceito este 
perfil de expressão gênica pode variar, devido a mudança no microambiente utilizado, por isso preferimos extrair o RNAm do próprio fragmento. Todavia, dado a dificuldade em se obter mais amostras de pele genital, obtivemos um número pequeno de casos, o que pode ter influenciado a ausência de diferenças significativas de nossos resultados.

Outro fator que pode estar envolvido na variabilidade do fenótipo genital da HAC $210 H$ é a backdoor pathway. Esta via já foi demonstrada em cangurus e tem fundamental importância na produção androgência fetal (Auchus 2004). Nesta via, o andrógeno mais potente, DHT, não é sintetizado a partir de seu precursor testosterona e sim pelo desvio da 170H-progesterona. Recentemente, foi demonstrado que esta via também é expressa em pacientes com HAC na vida pósnatal (Kamrath et al 2012) e, desta forma, supomos que a backdoor pathway também possa influênciar na variabilidade da virilização genital em pacientes com a forma clássica.

Concluímos que a variabilidade da virilização genital na hiperplasia adrenal congênita por deficiência da $210 \mathrm{H}$, é mais um dos problemas enigmáticos na biossíntese de esteróides e nas doenças de diferenciação sexual a serem resolvidos. Os dados deste estudo nos sugerem que o fenótipo de virilização genital deve ser consequente de uma interação poligênica, que envolve não só a presença de variantes funcionais, como diferenças de expressão tecidual local e também o envolvimento de diferentes vias da síntese androgênica. 


\section{CONCLUSÕES}


Nos estudos de correlação de variantes genéticas com o grau de virilização pré-natal de mulheres com a forma clássica da deficiência da 21-hidroxilase observamos que:

1) A severidade do comprometimento da atividade da 21-hidroxilase predita pelo genótipo se correlacionou com o grau de virilização pré-natal da genitália externa, justificando $9 \%$ da variabilidade.

2) As variantes rastreadas nos genes $C Y P 3 A 7$ e $P X R$ não influenciaram a intensidade de virilização pré-natal.

3) A variante rs2307424 do gene CAR influenciou em $25 \%$ o grau de virilização genital em pacientes com a forma clássica, contribuindo para um fenótipo de virilização mais intenso.

4) As variantes funcionais A503V POR, -71G HSD17B5, V89L SRD5A2, A49T SRD5A2 e nCAG RA não se correlacionaram com o fenótipo de viriliziação pré-natal.

5) A variante rs2518047 do gene HSD17B5 influenciou em 14\% o grau de virilização genital em pacientes com a forma clássica, contribuindo para um fenótipo de virilização mais intenso. 
6) Não identificamos diferenças na expressão dos genes HSD17B5, SRD5A1, SRD5A2 e RA em pele genital de pacientes portadoras de diferentes graus de virilização pré-natal. 


\section{ANEXOS}




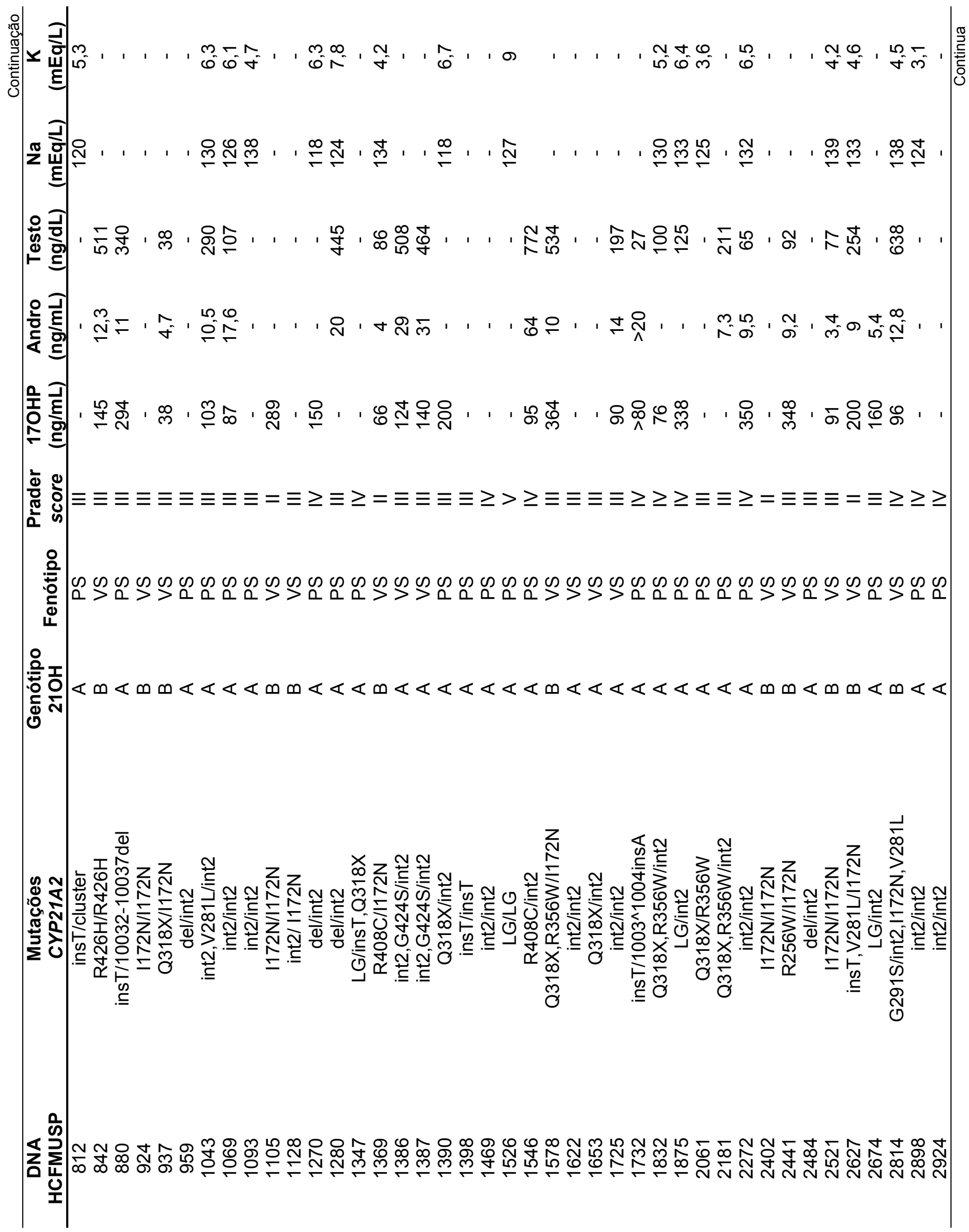




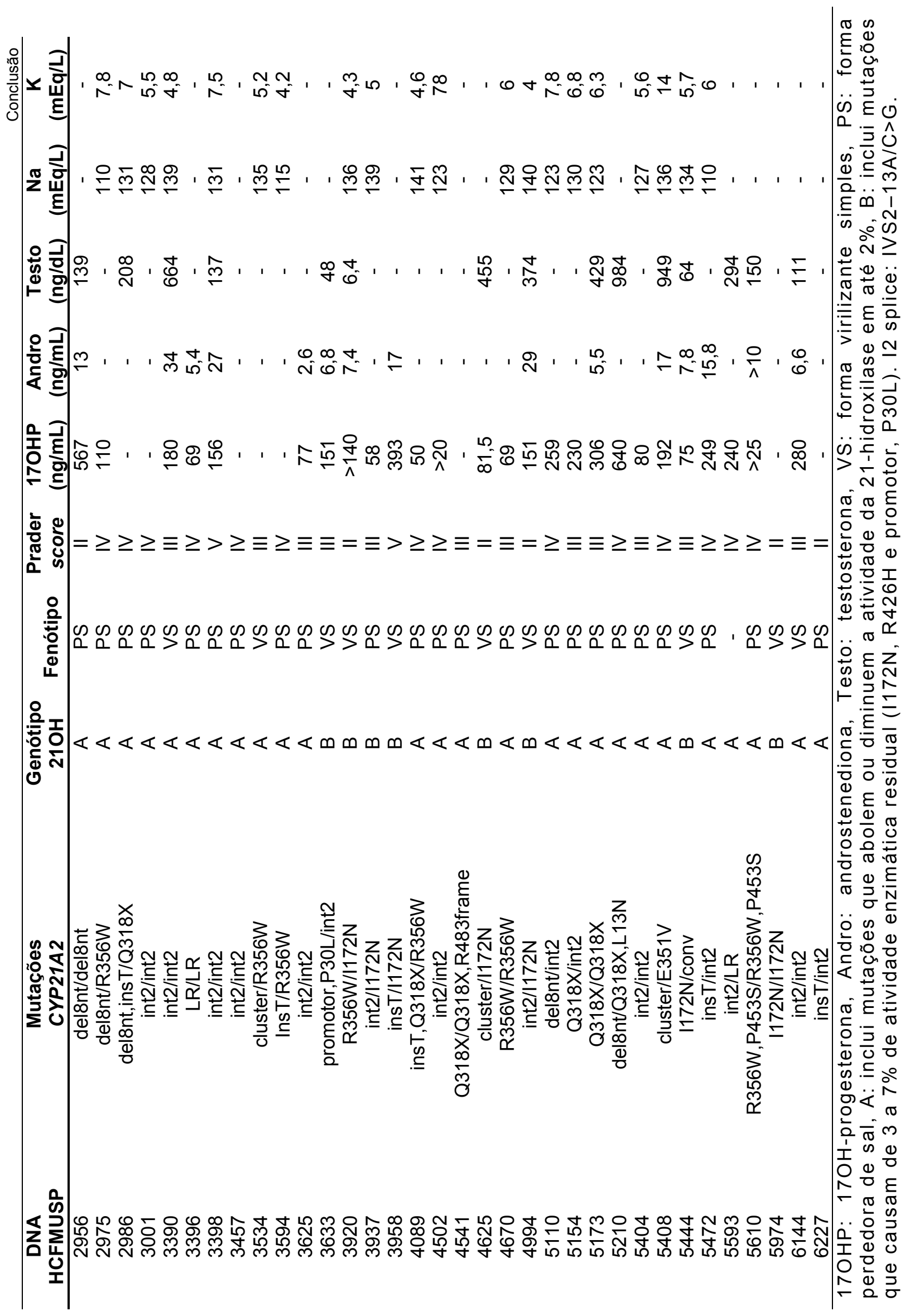




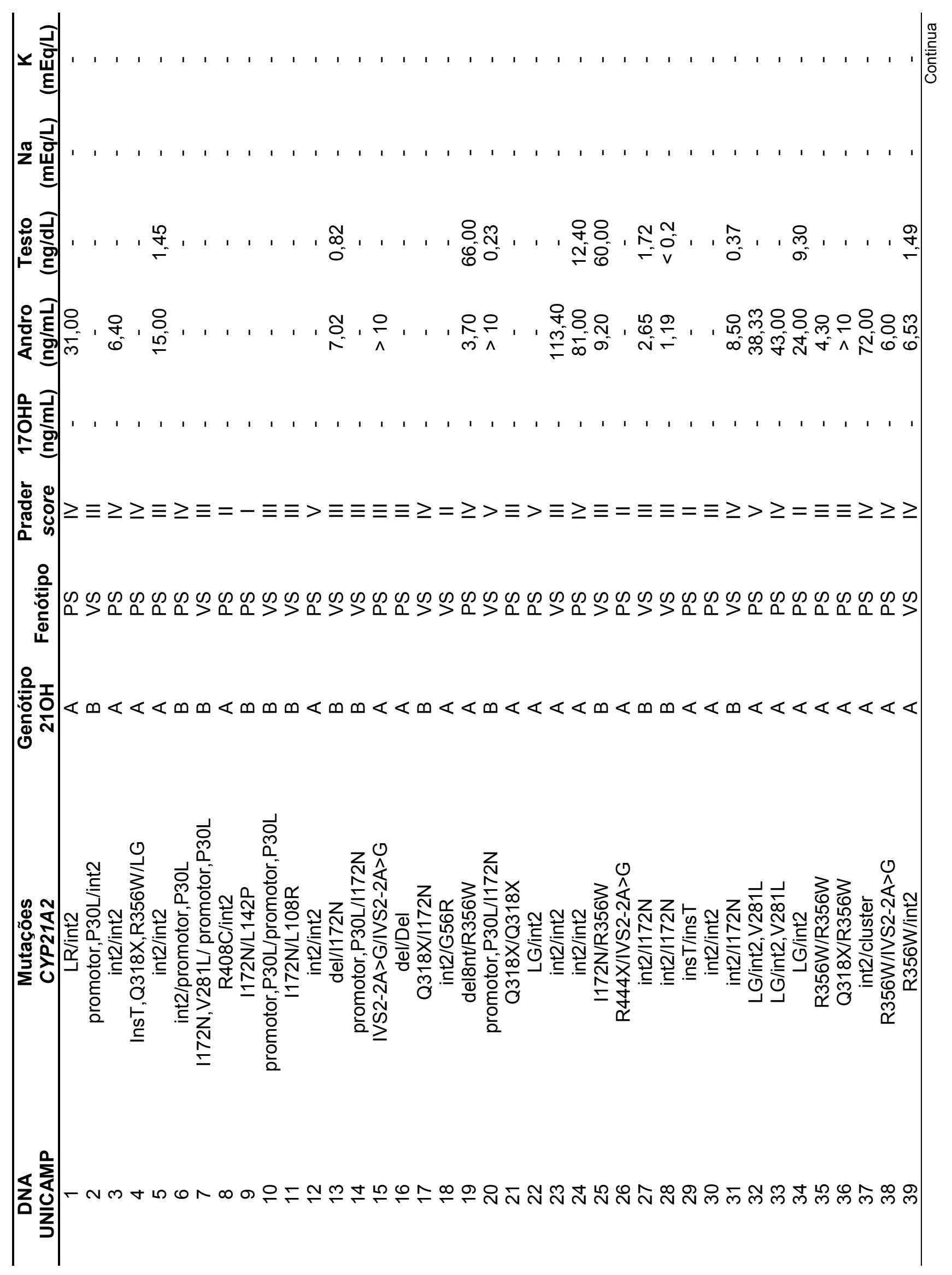



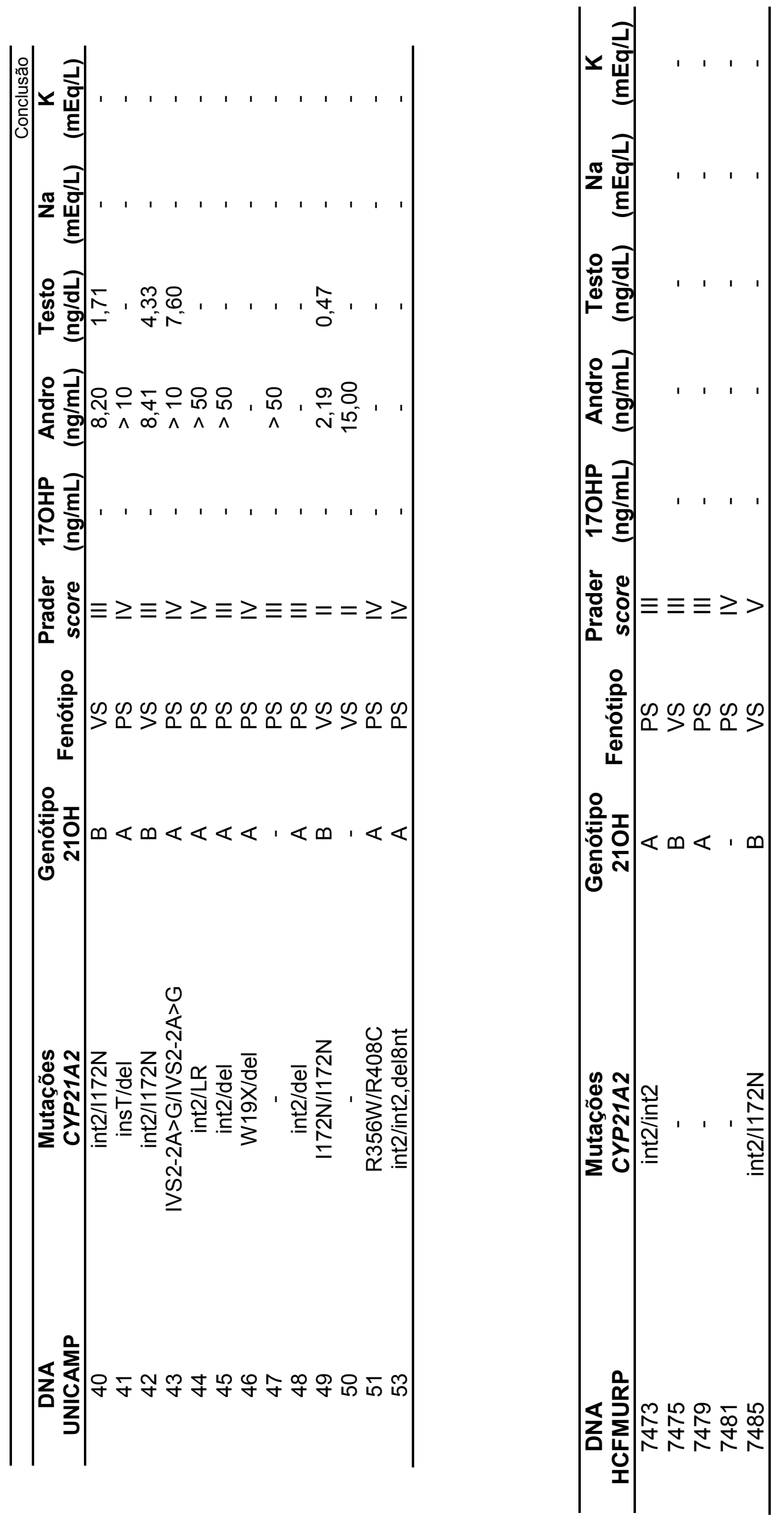


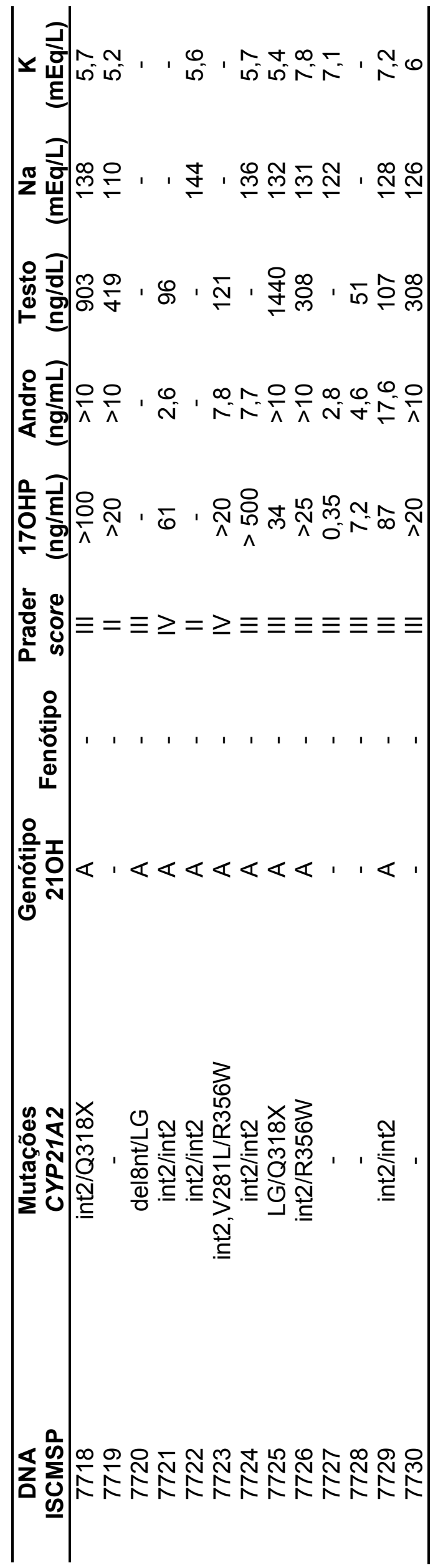


Tabela 2. Dados clínicos e moleculares do gene CYP21A2 das pacientes com hiperplasia adrenal congênita cujo fragmento de pele genital foi obtido durante genitoplastia corretiva.

\begin{tabular}{ccccc}
\hline DNA & $\begin{array}{c}\text { Forma } \\
\text { clínica }\end{array}$ & $\begin{array}{c}\text { Genótipo } \\
\text { 210H }\end{array}$ & $\begin{array}{c}\text { Mutações } \\
\text { CYP21A2 }\end{array}$ & $\begin{array}{c}\text { Prader } \\
\text { score }\end{array}$ \\
\hline 103 & PS & A & I2splice//2splice & III \\
7891 & PS & A & I2splice//2splice & III \\
2975 & PS & A & R356W/del & III \\
3633 & VS & B & I2splice/promotor,P30L & III \\
437 & VS & I & I2splice//2splice & III \\
5610 & PS & A & R356W,P453S/R356W,P453S & IV \\
3001 & PS & A & I2splice//2splice & IV \\
1732 & PS & A & insT/insA & IV \\
1875 & PS & A & I2splice/conv & IV \\
219 & VS & A & I2splice/Q318X & IV \\
3396 & PS & A & LR/LR & IV \\
8280 & VS & B & I2splice/l172N & IV \\
\hline
\end{tabular}

PS: forma perdedora de sal, VS: forma virilizante simples. I2splice: IVS2-13A/C>G, promotor: $-126 \mathrm{C}>\mathrm{T}$, insA: p.Ser170fs (c.511_512insA), insT: p.Leu307fs (c.923_924insT), conv: grandes conversões gênicas, LR: grand̄es rearranjos gênicos. 


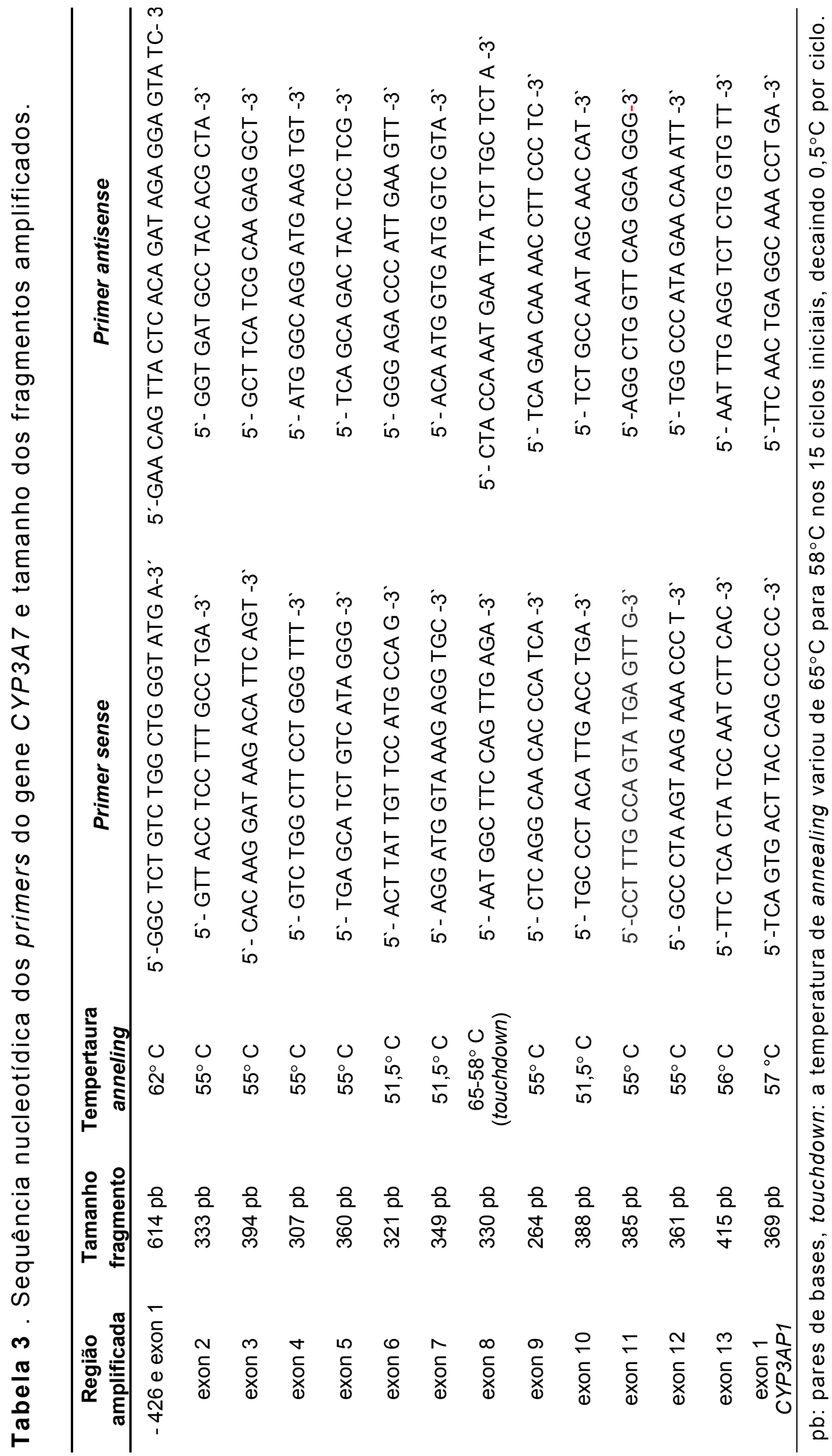




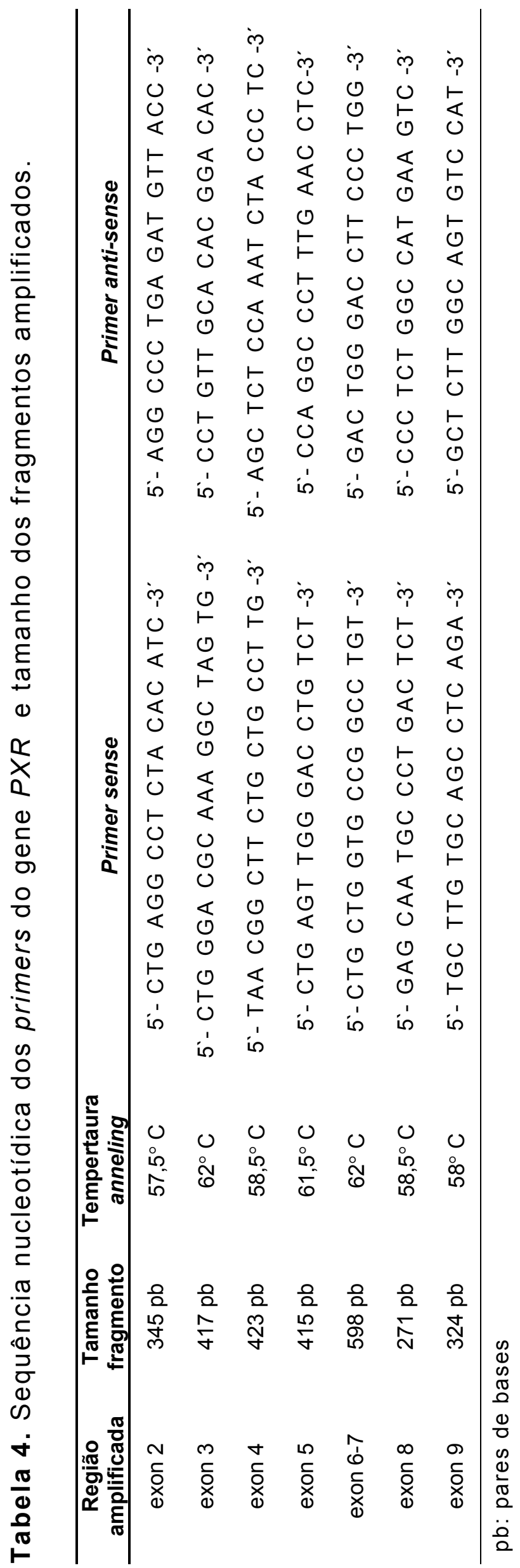




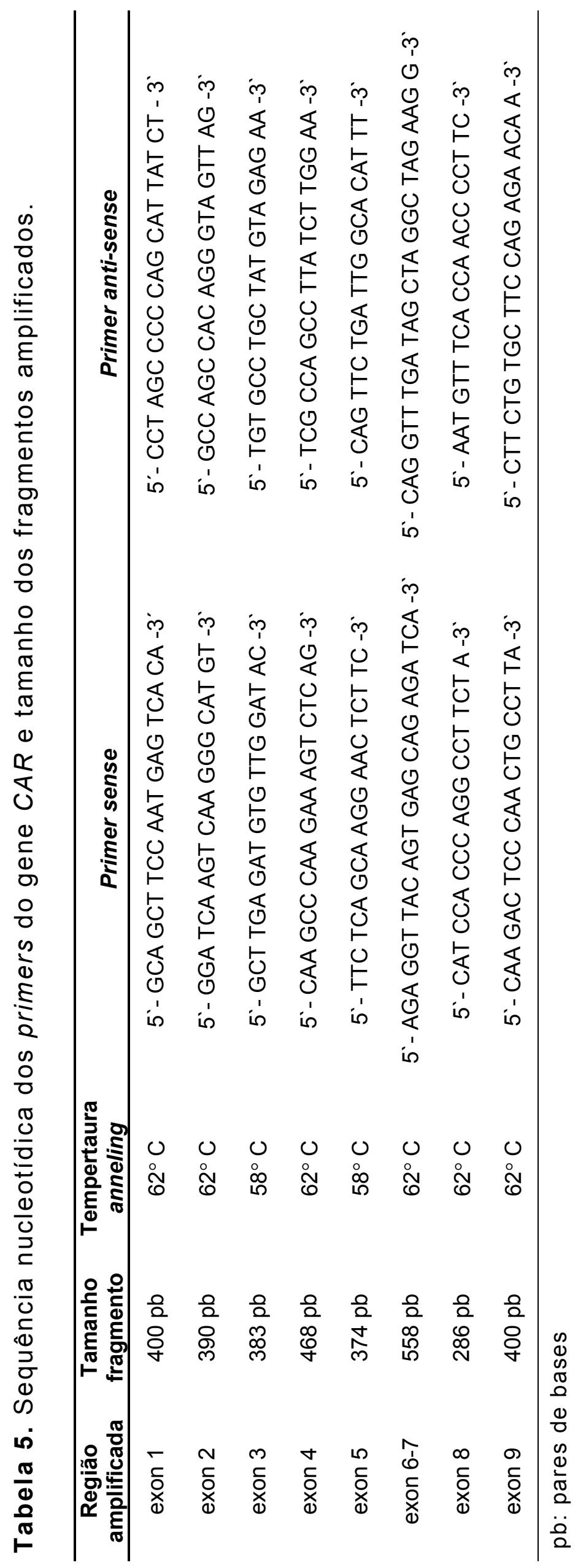




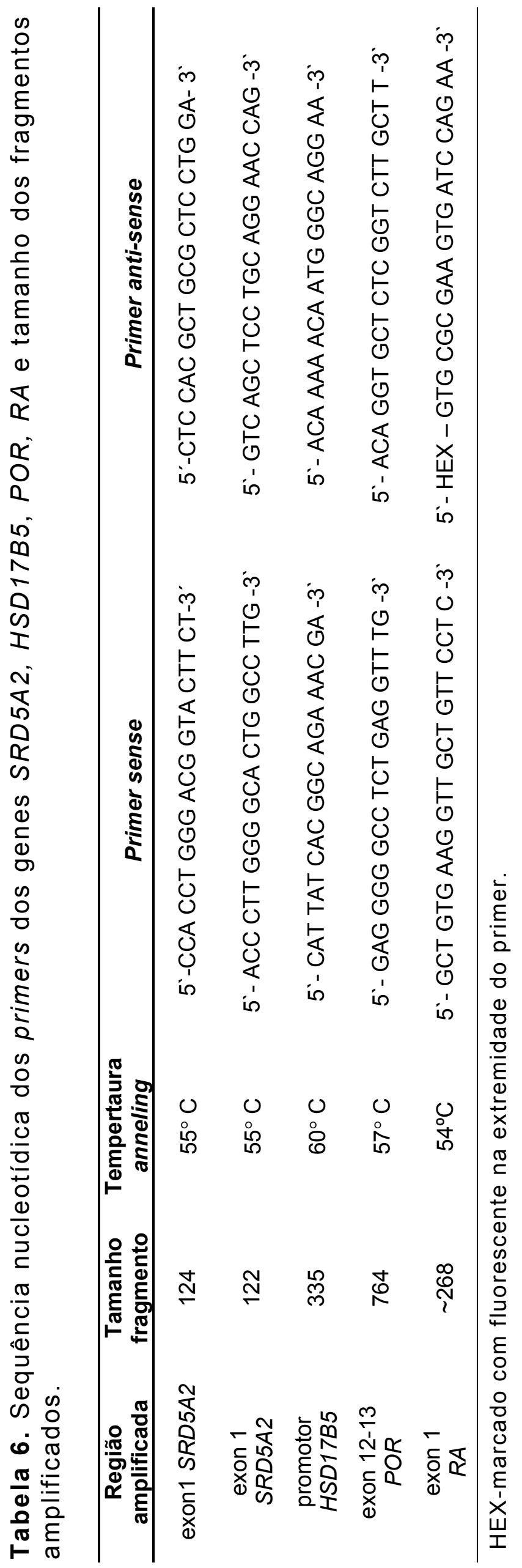


Tabela 7. Tabela dos genes endógenos e alvos estudados na expressão tecidual em pele genital.

\begin{tabular}{|c|c|c|c|}
\hline $\begin{array}{l}\text { Símbolo } \\
\text { do Gene }\end{array}$ & Nome do gene & Função & Ensaio \\
\hline CYC & ciclofilina A & $\begin{array}{l}\text { Catalisa a isomerização cis-trans de } \\
\text { ligações peptídicas }\end{array}$ & $4326316 \mathrm{E}$ \\
\hline GUS & $\beta$-glucuronidase & & $4326320 \mathrm{E}$ \\
\hline GAPDH & $\begin{array}{l}\text { Glyceraldeído-3-fosfatase- } \\
\text { desidrogenase }\end{array}$ & $\begin{array}{l}\text { Oxidoredutase na glicólise e na } \\
\text { gliconeogênese }\end{array}$ & $4326317 \mathrm{E}$ \\
\hline$B A$ & ßeta actina & Proteína estrutural do citoesqueleto & $4326315 \mathrm{E}$ \\
\hline$B 2 M$ & ßeta- 2 -microglobulina & $\begin{array}{l}\text { Molécula do complexo principal de } \\
\text { histocompatibilidade I }\end{array}$ & $4326319 \mathrm{E}$ \\
\hline HPRT & $\begin{array}{c}\text { Hypoxanthine } \\
\text { phosphoribosyl transferase }\end{array}$ & Síntese de purinas & $4326321 \mathrm{E}$ \\
\hline YWHAZ & $\begin{array}{l}\text { Polipeptídio zeta/ proteína } \\
\text { de ativação triptofano 5- } \\
\text { monooxigenase }\end{array}$ & $\begin{array}{l}\text { Transdução de sinal pela ligação a } \\
\text { resíduos de serina fosforilados em } \\
\text { uma variedade de moléculas } \\
\text { sinalizadora }\end{array}$ & Hs00237047_m1 \\
\hline TBP & $\begin{array}{l}\text { Proteína de ligação ao } \\
\text { TATA-box. }\end{array}$ & $\begin{array}{c}\text { Fator de transcrição da RNA } \\
\text { polimerase II }\end{array}$ & $4326322 E$ \\
\hline$T f R$ & Receptor de transferrina & Proteína carreadora de transferrina & $4326323 E$ \\
\hline PGK1 & Fosfoglicerato quinase 1 & Enzima glicolítica & $4326318 \mathrm{E}$ \\
\hline$U B C$ & Ubiquitina C & Degradação de proteínas & Hs00824723_m1 \\
\hline HMBS & $\begin{array}{l}\text { "Hydroxymethyl-bilane } \\
\text { synthase" }\end{array}$ & $\begin{array}{l}\text { Síntese do grupo Heme e } \\
\text { metabolismo porfirina }\end{array}$ & Hs00609297_m1 \\
\hline $\begin{array}{l}A K R 1 C 2 \text { ou } \\
\text { HSD } 17 B 3\end{array}$ & $\begin{array}{l}\text { aldo-keto reductase family } \\
1 \text { member } \mathrm{C} 2\end{array}$ & $\begin{array}{l}\text { Catalisam a redução dependente de } \\
\text { NADPH da carbonila }\end{array}$ & Hs00912742_m1 \\
\hline $\begin{array}{l}A K R 1 C 3 \text { ou } \\
\text { HSD } 17 B 5\end{array}$ & $\begin{array}{l}\text { Aldo-keto reductase family } \\
1 \text { member C3 }\end{array}$ & $\begin{array}{l}\text { Catalisam a redução dependente de } \\
\text { NADPH da carbonila }\end{array}$ & Hs00366267_m1 \\
\hline$A R$ & Receptor androgênico & $\begin{array}{l}\text { Transativa genes alvos ligado ao } \\
\text { seu ligante }\end{array}$ & Hs00907244_m1 \\
\hline$S R D 5 A 1$ & $5 \alpha$ redutase tipo 1 & $\begin{array}{l}\text { Catalisa a conversão de } \\
\text { testosterona em DHT }\end{array}$ & Hs00602694_mH \\
\hline SRD5A2 & $5 \alpha$ redutase tipo 2 & $\begin{array}{l}\text { Catalisa a conversão de } \\
\text { testosterona em DHT }\end{array}$ & Hs00165843_m1 \\
\hline
\end{tabular}


Tabela 8. Grau de virilização da genitália externa de pacientes com hiperplasia adrenal congênita nos genótipos mais frequentes da $210 \mathrm{H}$.

\begin{tabular}{cccccc}
\hline $\begin{array}{c}\text { Mutação } \\
\text { CYP21A2 }\end{array}$ & $\mathbf{n}(\%)$ & $\begin{array}{c}\text { Prader I+II } \\
(\mathbf{n})\end{array}$ & $\begin{array}{c}\text { Prader III } \\
(\mathbf{n})\end{array}$ & $\begin{array}{c}\text { Prader IV } \\
(\mathbf{n})\end{array}$ & $\begin{array}{c}\text { Prader V } \\
\text { (n) }\end{array}$ \\
\hline LR/LR & $3(2 \%)$ & 0 & 1 & 1 & 1 \\
LR/null & $7(4 \%)$ & 0 & 4 & 3 & 0 \\
I2 splice/I2 splice & $33(18 \%)$ & 1 & 19 & 11 & 2 \\
I2 splice/null & $47(25 \%)$ & 4 & 19 & 20 & 4 \\
I2 splice/p.I172N & $15(8 \%)$ & 2 & 10 & 2 & 1 \\
p.I172N/null & $21(11 \%)$ & 7 & 10 & 3 & 1 \\
p.I172N/p.I172N & $11(6 \%)$ & 6 & 5 & 0 & 0 \\
\hline
\end{tabular}

LR: grandes rearranjos (deleção CYP21A2 e grandes conversões), null: mutações que abolem a atividade enzimática: p.G110Efs, cluster, p.Leu307fs, p.R356W, p.Q318X, p.G291S, p.G424S, p.Arg483fs, IV2 -2A>G, p.Ser170fs, p.R444X, p.W129X e p.R408C. 
Tabela 9. Pacientes portadores de mutações novas no gene CYP21A2 de acordo com a forma clínica da hiperplasia adrenal congênita e com o grau de virilização da genitália externa.

\begin{tabular}{ccccc}
\hline DNA & $\begin{array}{c}\text { Mutação } \\
\text { CYP21A2 }\end{array}$ & $\begin{array}{c}\text { Genótipo } \\
\text { 210H }\end{array}$ & $\begin{array}{c}\text { Forma } \\
\text { clínica }\end{array}$ & $\begin{array}{c}\text { Prader } \\
\text { score }\end{array}$ \\
\hline $121^{1}$ & I2 splice/p.H365Y & A & PS & III \\
$596^{1}$ & I2splice/IVS2+5G>A,p.V281L & A & PS & V \\
$5408^{1}$ & cluster/p.E351V & A & PS & IV \\
$9^{2}$ & p.I172N/p.L142P & B & PS & I \\
$11^{2}$ & p.I172N/p.L108R & B & VS & III \\
$18^{2}$ & I2 splice/p.G56R & A & VS & II \\
$26^{2}$ & p.R444X/IVS2-2A>G & A & PS & II \\
\hline $\begin{array}{l}\text { HCFMUSP } \\
\text { simples }\end{array}$ & UNICAMP 2. PS: forma perdedora de sal, VS: forma virilizante
\end{tabular}




\section{REFERÊNCIAS}


Andersson S. Steroidogenic enzymes in skin. Eur J Dermatol. 11(4):293-5, 2001. Review.

Auchus RJ. The backdoor pathway to dihydrotestosterone. Trends Endocrinol Metab. 15(9):432-8, 2004.

Bachega TASS, Billerbeck AEC, Madureira G, Marcondes JAM, Longui CA, Leite MV, Arnhold IJP, Mendonca BB. Molecular genotype in Brazilian patients with classical and nonclassical forms of 21hydroxylase deficiency. J Clin Endocrinol Metab. 4416-19, 1998.

Bachega TA, Billerbeck AE, Madureira G, Arnhold IJ, Medeiros MA, Marcondes JA, Longui CA, Nicolau W, Bloise W, Mendonca BB. Low frequency of CYP2B deletions in Brazilian patients with congenital adrenal hyperplasia due to 21-hydroxylas deficiency. Hum Hered. 49(1):9-14, 1999.

Bachega TAAS, Billerbeck AEC, Parente EB, Lemos-Mariane SHV, Baptista MTM, Mello MP, GuerraJunior G, Kuperman H, Setian N, Damiani D, Castro M, Mendonça BB. Estudo multicêntrico de pacientes brasileiros com deficiência da 21-hidroxilase: correlação do genótipo com o fenótipo. Arq Bras Endocrinol Metab. 697-704, 2004.

Burk O, Tegude H, Koch I, Hustert E, Wolbold R, Glaeser H, Klein K, Fromm MF, Nuessler AK, Neuhaus P, Zanger UM, Eichelbaum M, Wojnowski L. Molecular mechanisms of polymorphic CYP3A7 expression in adult human liver and intestine. J Biol Chem. 277(27), 2002.

Cartharius K, Frech K, Grote K, Klocke B, Haltmeier M, Klingenhoff A, Frisch M, Bayerlein M, Werner T. MatInspector and beyond: promoter analysis based on transcription factor binding sites. Bioinformatics. 2933-42, 2005.

Chamberlain NL, Driver ED, Miesfeld RL. The length and location of CAG trinucleotide repeats in the androgen receptor N-terminal domain affect transactivation function. Nucleic Acids Res. 22(15):31816, 1994.

Cheon CK. Practical approach to steroid 5alpha-reductase type 2 deficiency. Eur J Pediatr. 170(1):18, 2011.

Chintamani, Kulshreshtha P, Chakraborty A, Singh L, Mishra AK, Bhatnagar D, Saxena S. Androgen receptor status predicts response to chemotherapy, not risk of breast cancer in Indian women. World J Surg Oncol. 8:64, 2010. 
Costa-Barbosa FA, Tonetto-Fernandes VF, Carvalho VM, Nakamura OH, Moura V, Bachega TA, Vieira JG, Kater CE. Superior discriminating value of ACTH-stimulated serum 21-deoxycortisol in identifying heterozygote carriers for 21-hydroxylase deficiency. Clin Endocrinol (Oxf). 73(6):700-6, 2010.

Daidone V, Gallinaro L, Grazia Cattini M, Pontara E, Bertomoro A, Pagnan A, Casonato A. An apparently silent nucleotide substitution (c.7056C>T) in the von Willebrand factor gene is responsible for type 1 von Willebrand disease. Haematologica. 96(6):881-7, 2011.

Desmet FO, Hamroun D, Lalande M, Collod-Beroud G, Claustres M, Beroud C. Human Splicing Finder: an online bioinformatics tool to predict splicing signals. Nucleic Acid Research, 2009.

Du J, Shi Y, Zhang A, Wang L, Xuan J, He G, Xu L, Xu M, Shu A, Yu L, Li X, Meng J, Feng G, Xing Q, He L. Screening for SNPs and haplotypes in the CYP3A7 gene in Chinese populations. Pharmacogenomics. 8(6):559-66, 2007.

Dupont B, Oberfield SE, Smithwick EM, Lee TD, Levine LS. Close genetic linkage between HLA and congenital adrenal hyperplasia (21-hydroxylase deficiency). Lancet. 2(8052-8053):1309-12, 1977.

Fernández-Cancio M, Audí L, Andaluz P, Torán N, Piró C, Albisu M, Gussinyé M, Yeste $D$, Clemente M, Martínez-Mora J, Blanco A, Granada ML, Marco M, Ferragut J, López-Siguero JP, Beneyto M, Carles C, Carrascosa A. SRD5A2 gene mutations and polymorphisms in Spanish 46,XY patients with a disorder of sex differentiation. Int J Androl. 34(6 Pt 2):526-35, 2011.

Finkielstain GP, Chen W, Mehta SP, Fujimura FK, Hanna RM, Van Ryzin C, McDonnell NB, Merke DP. Comprehensive genetic analysis of 182 unrelated families with congenital adrenal hyperplasia due to 21-hydroxylase deficiency. J Clin Endocrinol Metab. 96(1):E161-72, 2011.

Gelmann EP. Molecular biology of the androgen receptor. J Clin Oncol. 20(13):3001-15, 2002.

Giwercman YL, Nordenskjöld A, Ritzén EM, Nilsson KO, Ivarsson SA, Grandell U, Wedell A. An androgen receptor gene mutation (E653K) in a family with congenital adrenal hyperplasia due to steroid 21-hydroxylase deficiency as well as in partial androgen insensitivity. J Clin Endocrinol Metab. 87(6):2623-8, 2002.

Goodarzi MO, Shah NA, Antoine HJ, Pall M, Guo X, Azziz R. Variants in the 5alpha-reductase type 1 and type 2 genes are associated with polycystic ovary syndrome and the severity of hirsutism in affected women. J Clin Endocrinol Metab. 91(10):4085-91, 2006. 
Goodarzi MO, Xu N, Azziz R. Association of CYP3A7*1C and serum dehydroepiandrosterone sulfate levels in women with polycystic ovary syndrome. J Clin Endocrinol Metab. 93(7):2909-12, 2008a).

Goodarzi MO, Jones MR, Antoine HJ, Pall M, Chen YD, Azziz R. Nonreplication of the type 5 17betahydroxysteroid dehydrogenase gene association with polycystic ovary syndrome. J Clin Endocrinol Metab. 93(1):300-3, 2008b).

Goossens K, Juniarto AZ, Timmerman MA, Faradz SM, Wolffenbuttel KP, Drop SL, de Jong FH. Lack of correlation between phenotype and genotype in untreated 21-hydroxylase-deficient Indonesian patients. Clin Endocrinol (Oxf). 71(5):628-35, 2009.

Hayashi G, Faure C, Brondi MF, Vallejos C, Soares D, Oliveira E, Brito VN, Mendonca BB, Bachega TA. Weight-adjusted neonatal $170 \mathrm{H}$-progesterone cutoff levels improve the efficiency of newborn screening for congenital adrenal hyperplasia. Arq Bras Endocrinol Metabol. 55(8):632-7, 2011.

He P, Court MH, Greenblatt DJ, von Moltke LL. Human pregnane $X$ receptor: genetic polymorphisms, alternative mRNA splice variants, and cytochrome P450 3A metabolic activity. J Clin Pharmacol. 46(11):1356-69, 2006.

Higashi Y, Tanae A, Inoue H, Hiromasa T, Fujii-Kuriyama Y. Aberrant splicing and missense mutations cause steroid 21-hydroxylase [P-450(C21)] deficiency in humans: possible gene conversion products. Proc Natl Acad Sci U S A. 85(20):7486-90, 1988.

Higashi, Y.; Hiromasa, T.; Tanae, A.; Miki, A.; Nakura, J.; Kondo, T.; Ohura, T.; Ogawa,T.; Nakayama, K.; Fujii, K.Y. Effects of individual mutations in the p450 (c21) pseudogene on the P450 (c21) activity and their distribution in the patient genomes of congenital steroid 21 hydroxylase deficiency. J Biochen. 101:638-57, 1991.

Holterhus PM, Deppe U, Werner R, Richter-Unruh A, Bebermeier JH, Wünsch L, Krege S, Schweikert HU, Demeter J, Riepe F, Hiort O, Brooks JD. Intrinsic androgen-dependent gene expression patterns revealed by comparison of genital fibroblasts from normal males and individuals with complete and partial androgen insensitivity syndrome. BMC Genomics. 8:376, 2007.

Hoppe U, Holterhus PM, Wünsch L, Jocham D, Drechsler T, Thiele S, Marschke C, Hiort O. Tissuespecific transcription profiles of sex steroid biosynthesis enzymes and the androgen receptor. $\mathrm{J}$ Mol Med. 84(8):651-9, 2006. 
Hoppe U, Wünsch L, Holterhus PM, Jocham D, Richter-Unruh A, Hiort O. Altered transcription profiles of key-enzymes of androgen biosynthesis in genital skin fibroblasts from patients with 46,XY disorders of sex development (DSD). Sex Dev. 1(4):230-7, 2007.

Huang N,Agrawal V,Giacomini KM,Miller WL. Genetics of P450 oxidoreductase: sequence variation in 842 individuals of four ethnicities and activities of 15 missense mutations. Proc Natl Acad Sci U S A. 105(5):1733-8, 2008.

Hustert E, Zibat A, Presecan-Siedel E, Eiselt R, Mueller R, Fuss C, Brehm I, Brinkmann U, Eichelbaum M, Wojnowski L, Burk O. Natural protein variants of pregnane $X$ receptor with altered transactivation activity toward CYP3A4. Drug Metab Dispos. 29(11):1454-9, 2001.

Ibáñez L, Ong KK, Mongan N, Jääskeläinen J, Marcos MV, Hughes IA, De Zegher F, Dunger DB. Androgen receptor gene CAG repeat polymorphism in the development of ovarian hyperandrogenism. J Clin Endocrinol Metab. 88(7):3333-8, 2003.

Ikeda S, Kurose K, Ozawa S, Sai K, Hasegawa R, Komamura K, Ueno K, Kamakura S, Kitakaze M, Tomoike H, Nakajima T, Li Z,Habuchi T,Mitsumori K,Kamoto T,Kinoshitu H,Segawa T,Ogawa O,Kato T. Association of V89L SRD5A2 polymorphism with prostate cancer development in a Japanese population. The Journal of urology. 169(6):2378-81, 2003.

Ikeda S, Kurose K, Jinno H, Sai K, Ozawa S, Hasegawa R, Komamura K, Kotake T, Morishita H, Kamakura S, Kitakaze M, Tomoike H, Tamura T, Yamamoto N, Kunitoh H, Yamada $Y$, Ohe $Y$, Shimada Y, Shirao K, Kubota K, Minami H, Ohtsu A, Yoshida T, Saijo N, Saito Y, Sawada J. Functional analysis of four naturally occurring variants of human constitutive androstane receptor. Mol Genet Metab. 86(1-2):314-9, 2005.

Kamrath C, Hochberg Z, Hartmann MF, Remer T, Wudy SA. Increased activation of the alternative "backdoor" pathway in patients with 21-hydroxylase deficiency: evidence from urinary steroid hormone analysis. J Clin Endocrinol Metab. 97(3):E367-75, 2012.

Kaupert LC, Billerbeck AE, Brito VN, Mendonca BB, Bachega TA. Could the leukocyte $x$ chromosome inactivation pattern be extrapolated to hair bulbs? Horm Res Paediatr. 73(4):238-43, 2010.

Kristiansen W, Haugen TB, Witczak O, Andersen JM, Fosså SD, Aschim EL. CYP1A1, CYP3A5 and CYP3A7 polymorphisms and testicular cancer susceptibility. Int J Androl. 34(1):77-83, 2011. 
Krone N, Braun A, Roscher AA, Knorr D, Schwarz HP. Predicting phenotype in steroid 21-hydroxylase deficiency? Comprehensive genotyping in 155 unrelated, well defined patients from southern Germany. J Clin Endocrinol Metab. 85(3):1059-65, 2000.

Kuasne H, Rodrigues IS, Fuganti PE, Losi-Guembarovski R, Ito K, Kishima MO, Rodrigues MA, Rogatto SR, Santos RM, Cólus IM. Polymorphisms in the AR and PSA genes as markers of susceptibility and aggressiveness in prostate cancer. Cancer Invest. 28(9):917-24, 2010.

La Spada AR, Clark AW. Inherited neurodegenerative disorders caused by CAG/polyglutamine tract expansions: symposium introduction. Brain Pathol. 7(3):877-80, 1997.

Lamba JK, Lin YS, Schuetz EG, Thummel KE. Genetic contribution to variable human CYP3Amediated metabolism. Adv Drug Deliv Rev. 54(10):1271-94, 2002.

Lee AJ, Cai MX, Thomas PE, Conney AH, Zhu BT. Characterization of the oxidative metabolites of 17 beta-estradiol and estrone formed by 15 selectively expressed human cytochrome p450 isoforms. Endocrinology. 144(8):3382-98, 2003.

Leeder JS, Gaedigk R, Marcucci KA, Gaedigk A, Vyhlidal CA, Schindel BP, Pearce RE. Variability of CYP3A7 expression in human fetal liver. J Pharmacol Exp Ther. 314(2):626-35, 2005.

Legro RS, Shahbahrami B, Lobo RA, Kovacs BW. Size polymorphisms of the androgen receptor among female Hispanics and correlation with androgenic characteristics. Obstet Gynecol. 83(5 Pt 1):701-6, 1994.

Li Z, Habuchi T, Mitsumori K, Kamoto T, Kinoshitu H, Segawa T, Ogawa O, Kato T. Association of V89L SRD5A2 polymorphism with prostate cancer development in a Japanese population. J Urol. 169(6):2378-81, 2003.

Li Q, Yang G, Wang Y, Zhang X, Sang Q, Wang H, Zhao X, Xing Q, He L, Wang L.

Common genetic variation in the 3'-untranslated region of gonadotropin-releasing hormone receptor regulates gene expression in cella and is associated with thyroid function, insulin secretion as well as insulin sensitivity in polycystic ovary syndrome patients. Hum Genet. 129(5):553-61, 2011.

Liu CC, Lee YC, Wang CJ, Yeh HC, Li WM, Wu WJ, Huang CN, Bao BY, Huang CH, Huang SP. The Impact of Androgen Receptor CAG Repeat Polymorphism on Andropausal Symptoms in Different Serum Testosterone Levels. J Sex Med. [Epub ahead of print], 2012. 
Lubahn DB, Joseph DR, Sullivan PM, Willard HF, French FS, Wilson EM.

Cloning of human androgen receptor complementary DNA and localization to the $X$ chromosome. Science. 240(4850):327-30, 1988.

Luu-The V. Analysis and characteristics of multiple types of human 17beta-hydroxysteroid dehydrogenase. J Steroid Biochem Mol Biol. 76(1-5):143-51, 2001. Review.

Makridakis N, Ross RK, Pike MC, Chang L, Stanczyk FZ, Kolonel LN, Shi CY, Yu MC, Henderson BE, Reichardt JK. A prevalent missense substitution that modulates activity of prostatic steroid 5alphareductase. Cancer Res. 57(6):1020-2, 1997.

Marino R, Ramirez P, Galeano J, Perez Garrido N, Rocco C, Ciaccio M, Warman DM, Guercio G, Chaler E, Maceiras M, Bergadá I, Gryngarten M, Balbi V, Pardes E, Rivarola MA, Belgorosky A. Steroid 21-hydroxylase gene mutational spectrum in 454 Argentinean patients: genotype-phenotype correlation in a large cohort of patients with congenital adrenal hyperplasia. Clin Endocrinol (Oxf). 75(4):427-435, 2011.

Marioli DJ, Saltamavros AD, Vervita V, Koika V, Adonakis G, Decavalas G, Markou KB, Georgopoulos NA. Association of the 17-hydroxysteroid dehydrogenase type 5 gene polymorphism $(-71 \mathrm{~A} / \mathrm{G}$ HSD17B5 SNP) with hyperandrogenemia in polycystic ovary syndrome (PCOS). Fertil Steril. 92(2):648-52, 2009.

Mendonca BB, Arnhold IJ, Bloise W, Andersson S, Russell DW, Wilson JD. 17Beta-hydroxysteroid dehydrogenase 3 deficiency in women. J Clin Endocrinol Metab. 84(2):802-4, 1999.

Mercè Fernández-Balsells M, Muthusamy K, Smushkin G, Lampropulos JF, Elamin MB, Abu Elnour NO, Elamin KB, Agrwal N, Gallegos-Orozco JF, Lane MA, Erwin PJ, Montori VM, Murad MH. Prenatal dexamethasone use for the prevention of virilization in pregnancies at risk for classical congenital adrenal hyperplasia because of 21-hydroxylase (CYP21A2) deficiency: a systematic review and metaanalyses. Clin Endocrinol (Oxf). 73(4):436-44, 2010. Review.

Miller KK, Cai J, Ripp SL, Pierce WM Jr, Rushmore TH, Prough RA. Stereo- and regioselectivity account for the diversity of dehydroepiandrosterone (DHEA) metabolites produced by liver microsomal cytochromes P450. Drug Metab Dispos. 32(3):305-13, 2004.

Miller WL. Minireview: regulation of steroidogenesis by electron transfer. Endocrinology. 146(6):254450, 2005. 
Miller WL, Agrawal V, Sandee D, Tee MK, Huang N, Choi JH, Morrissey K, Giacomini KM. Consequences of POR mutations and polymorphisms. Mol Cell Endocrinol. 336(1-2):174-9, 2010.

Mojsin M, Stevanovic M. PBX1 and MEIS1 up-regulate SOX3 gene expression by direct interaction with a consensus binding site within the basal promoter region. Biochem J. 425(1):107-16, 2009.

Moreira RP, Jorge AA, Gomes LG, Kaupert LC, Massud Filho J, Mendonca BB, Bachega TA. Pharmacogenetics of glucocorticoid replacement could optimize the treatment of congenital adrenal hyperplasia due to 21-hydroxylase deficiency. Clinics (Sao Paulo). 66(8):1361-6, 2011.

Nenonen HA, Giwercman A, Hallengren E, Giwercman YL. Non-linear association between androgen receptor CAG repeat length and risk of male subfertility--a meta-analysis. Int J Androl. 34(4):327-32, 2011.

Pascussi JM, Jounaidi Y, Drocourt L, Domergue J, Balabaud C, Maurel P, Vilarem MJ. Evidence for the presence of a functional pregnane $X$ receptor response element in the CYP3A7 promoter gene. Biochem Biophys Res Commun. 260(2):377-81, 1999.

Paulino LC, Araujo M, Guerra G Jr, Marini SH, De Mello MP. Mutation distribution and CYP21/C4 locus variability in Brazilian families with the classical form of the 21-hydroxylase deficiency. Acta Paediatr. 88(3):275-83, 1999.

Petry CJ, Ong KK, Wingate DL, de Zegher F, Ibáñez L, Dunger DB. Lack of association between common polymorphisms in the 17beta-hydroxysteroid dehydrogenase type $V$ gene (HSD17B5) and precocious pubarche. J Steroid Biochem Mol Biol. 105(1-5):176-80, 2007.

Prader A. Genital findings in the female pseudo-hermaphroditism of the congenital adrenogenital syndrome; morphology, frequency, development and heredity of the different genital forms. Helv Paediatr Acta. 231-248, 1954.

Qin K, Rosenfield RL. Characterization of the basal promoter element of the human type 5 17betahydroxysteroid dehydrogenase gene. Biochim Biophys Acta. 1728(3):115-25, 2005.

Qin K, Ehrmann DA, Cox N, Refetoff S, Rosenfield RL. Identification of a functional polymorphism of the human type 5 17beta-hydroxysteroid dehydrogenase gene associated with polycystic ovary syndrome. J Clin Endocrinol Metab. 91(2):529, 2006. 
Rocha RO, Billerbeck AE, Pinto EM, Melo KF, Lin CJ, Longui CA, Mendonca BB, Bachega TA. The degree of external genitalia virilization in girls with 21-hydroxylase deficiency appears to be influenced by the CAG repeats in the androgen receptor gene. Clin Endocrinol (Oxf). 68(2):226-32, 2008.

Rodríguez-Antona C, Jande M, Rane A, Ingelman-Sundberg M. Identification and phenotype characterization of two CYP3A haplotypes causing different enzymatic capacity in fetal livers. Clin Pharmacol Ther. 77(4):259-70, 2005a).

Rodríguez-Antona C, Axelson M, Otter C, Rane A, Ingelman-Sundberg M. A novel polymorphic cytochrome P450 formed by splicing of CYP3A7 and the pseudogene CYP3AP1. J Biol Chem. 280(31), 2005b).

Schüring AN, Welp A, Gromoll J, Zitzmann M, Sonntag B, Nieschlag E, Greb RR, Kiesel L. Role of the CAG repeat polymorphism of the androgen receptor gene in polycystic ovary syndrome (PCOS). Exp Clin Endocrinol Diabetes. 120(2):73-9, 2012.

Siemes C, Visser LE, de Jong FH, Coebergh JW, Uitterlinden AG, Hofman A, Stricker BH, van Schaik $\mathrm{RH}$. Cytochrome P450 3A gene variation, steroid hormone serum levels and prostate cancer--The Rotterdam Study. Steroids. 75(12):1024-32, 2010.

Smit $P$, van Schaik $R H$, van der Werf $M$, van den Beld AW, Koper JW, Lindemans J, Pols HA, Brinkmann $\mathrm{AO}$, de Jong $\mathrm{FH}$, Lamberts SW. A common polymorphism in the CYP3A7 gene is associated with a nearly $50 \%$ reduction in serum dehydroepiandrosterone sulfate levels. J Clin Endocrinol Metab. 90(9):5313-6, 2005.

Speiser PW, Dupont J, Zhu D, Serrat J, Buegeleisen M, Tusie-Luna MT, Lesser M, New MI, White PC. Disease expression and molecular genotype in congenital adrenal hyperplasia due to 21-hydroxylase deficiency. J Clin Invest. 90(2):584-95, 1992.

Stevens JC, Hines RN, Gu C, Koukouritaki SB, Manro JR, Tandler PJ, Zaya MJ. Developmental expression of the major human hepatic CYP3A enzymes. J Pharmacol Exp Ther. 307(2):573-82, 2003.

Surekha D, Sailaja K, Rao DN, Padma T, Raghunadharao D, Vishnupriya S. Association of a CYP17 gene polymorphism with development of breast cancer in India. Asian Pac J Cancer Prev. 11(6):16537, 2010. 
Thai HT, Kalbasi M, Lagerstedt K, Frisén L, Kockum I, Nordenskjöld A. The valine allele of the V89L polymorphism in the 5-alpha-reductase gene confers a reduced risk for hypospadias. J Clin Endocrinol Metab. 90(12):6695-8, 2005.

Torres N, Mello MP, Germano CM, Elias LL, Moreira AC, Castro M. Phenotype and genotype correlation of the microconversion from the CYP21A1P to the CYP21A2 gene in congenital adrenal hyperplasia. Braz J Med Biol Res. 36(10):1311-8, 2003.

Tusie-Luna MT, Traktman P, White PC. Determination of functional effects of mutations in the steroid 21-hydroxylase gene (CYP21) using recombinant vaccinia virus. J Biol Chem. 265(34):20916-22, 1990.

Tut TG, Ghadessy FJ, Trifiro MA, Pinsky L, Yong EL. Long polyglutamine tracts in the androgen receptor are associated with reduced trans-activation, impaired sperm production, and male infertility. J Clin Endocrinol Metab. 82(11):3777-82, 1997.

Vandesompele J, De Preter K, Pattyn F, Poppe B, Van Roy N, De Paepe A, Speleman F. Accurate normalization of real-time quantitative RT-PCR data by geometric averaging of multiple internal control genes. Genome Biol. 3(7), 2002.

Vottero A, Stratakis CA, Ghizzoni L, Longui CA, Karl M, Chrousos GP. Androgen receptor-mediated hypersensitivity to androgens in women with nonhyperandrogenic hirsutism: skewing of $X$ chromosome inactivation. J Clin Endocrinol Metab. 84(3):1091-5, 1999.

Vyhlidal CA, Gaedigk R, Leeder JS. Nuclear receptor expression in fetal and pediatric liver: correlation with CYP3A expression. Drug Metab Dispos. 34(1):131-7, 2006.

Wedell A, Thilén A, Ritzén EM, Stengler B, Luthman H. Mutational spectrum of the steroid 21hydroxylase gene in Sweden: implications for genetic diagnosis and association with disease manifestation. J Clin Endocrinol Metab. 78(5):1145-52, 1994.

Welzel M, Schwarz HP, Hedderich J, Dörr HG, Binder G, Brämswig JH, Krude H, Richter-Unruh A, Niedziela M, Gromoll J, Krone N, Riepe FG, Holterhus PM. No correlation between androgen receptor $C A G$ and GGN repeat length and the degree of genital virilization in females with 21-hydroxylase deficiency. J Clin Endocrinol Metab. 95(5):2443-50, 2010.

White PC, Speiser PW. Congenital adrenal hyperplasia due to 21-hydroxylase deficiency. Endocr Rev. 21(3):245-91, 2000. Review. 
White PC, New MI, Dupont B. Structure of human steroid 21-hydroxylase genes.

Proc Natl Acad Sci U S A. 83(14):5111-5, 1986.

Witchel SF, Smith R, Crivellaro CE, Della Manna T, Dichtchekenian V, Setian N, Damiani D. CYP21 mutations in Brazilian patients with 21-hydroxylase deficiency. Hum Genet. 106(4):414-9, 2000.

Witchel SF, Azziz R. Nonclassic congenital adrenal hyperplasia. Int J Pediatr Endocrinol. 2010:625105, 2010.

Witchel SF, Azziz R. Congenital adrenal hyperplasia. J Pediatr Adolesc Gynecol. 24(3):116-26, 2011. Review.

Wyen C, Hendra H, Siccardi M, Platten M, Jaeger H, Harrer T, Esser S, Bogner JR, Brockmeyer NH, Bieniek B, Rockstroh J, Hoffmann C, Stoehr A, Michalik C, Dlugay V, Jetter A, Knechten H, Klinker H, Skaletz-Rorowski A, Fätkenheuer G, Egan D, Back DJ, Owen A; German Competence Network for HIVIAIDS Coordinators. Cytochrome P450 2B6 (CYP2B6) and constitutive androstane receptor (CAR) polymorphisms are associated with early discontinuation of efavirenz-containing regimens. J Antimicrob Chemother. 66(9):2092-8, 2011.

Zeigler-Johnson CM, Walker AH, Mancke B, Spangler E, Jalloh M, McBride S, Deitz A, Malkowicz SB, Ofori-Adjei D, Gueye SM, Rebbeck TR. Ethnic differences in the frequency of prostate cancer susceptibility alleles at SRD5A2 and CYP3A4. Hum Hered. 54(1):13-21, 2002.

Zhang J, Kuehl P, Green ED, Touchman JW, Watkins PB, Daly A, Hall SD, Maurel P, Relling M, Brimer C, Yasuda K, Wrighton SA, Hancock M, Kim RB, Strom S, Thummel K, Russell CG, Hudson JR Jr, Schuetz EG, Boguski MS. The human pregnane $X$ receptor: genomic structure and identification and functional characterization of natural allelic variants. Pharmacogenetics. 11(7):55572, 2001.

Zhang B, Xie W, Krasowski MD. PXR: a xenobiotic receptor of diverse function implicated in pharmacogenetics. Pharmacogenomics. 9(11):1695-709, 2008. 